GEAP-10385

AEC Research and

Development Report

July 1971

This report was prepared as an account of work sponsored by the United States Government. Neither the United States nor the United States Atomic Energy Commission, nor any of their employees, nor any of their contractors, subcontractors, or ees, nor any of makes any warranty, express or implied legal liability or responsibility for the accuracy, com. pleteness or usefulness of any information, apparatus, product or process disclosed, or represents apparatus, product or process disclosed, or represents that its use
would not infringe privately owned rights.

\title{
HIGH BURNUP PERFORMANCE \\ OF \\ POWDER AND PELLET \\ MIXED-OXIDE FUEL
}

Approved:

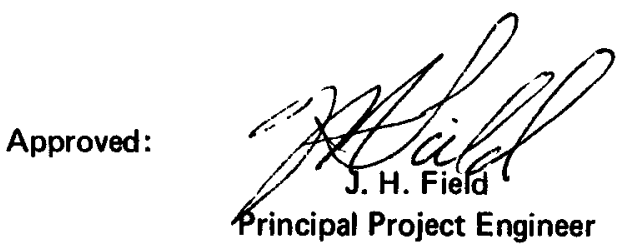

K. J. Perry

W. E. Baily
Approved:

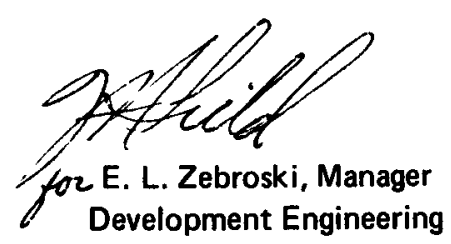

U. S. Atomic Energy Commission

Contract AT (04-3)-189

Project Agreement 10

BREEDER REACTOR DEPARTMENT • GENERAL ELECTRIC COMPANY

SUNNYVALE, CALIFORNIA 94086

6337-Dev.Eng.64

\section{GENERAL ELETRIC}




\section{NOTICE}

This report was prepared as an account of work sponsored by the United States Government. Neither the United States nor the United States Atomic Energy Commission, nor any of their employees, nor any of their contractors, subcontractors, or their employees, makes any warranty, express or implied, or assumes any legal liability or responsibility for the accuracy, completeness or usefulness of any information, apparatus, product or process disclosed, or represents that its use would not infringe privately owned rights. 


\section{DISCLAIMER}

This report was prepared as an account of work sponsored by an agency of the United States Government. Neither the United States Government nor any agency Thereof, nor any of their employees, makes any warranty, express or implied, or assumes any legal liability or responsibility for the accuracy, completeness, or usefulness of any information, apparatus, product, or process disclosed, or represents that its use would not infringe privately owned rights. Reference herein to any specific commercial product, process, or service by trade name, trademark, manufacturer, or otherwise does not necessarily constitute or imply its endorsement, recommendation, or favoring by the United States Government or any agency thereof. The views and opinions of authors expressed herein do not necessarily state or reflect those of the United States Government or any agency thereof. 


\section{DISCLAIMER}

Portions of this document may be illegible in electronic image products. Images are produced from the best available original document. 


\section{TABLE OF CONTENTS}

ABSTRACT . . . . . . . . . . . . . . . . . . . . . . . . . . 1

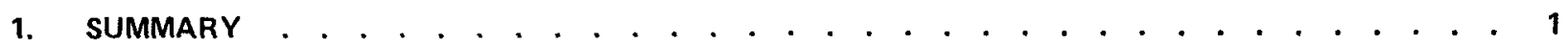

2. INTRODUCTION . . . . . . . . . . . . . . . . . . . . . . . . . . . . . . 1

3. DESCRIPTION OF EXPERIMENT . . . . . . . . . . . . . . . . . . . . . . . . . . . . 1

3.1 Irradiation Capsule Design . . . . . . . . . . . . . . . . . . . . . . . . . 1

3.2 Fuel Pin Design . . . . . . . . . . . . . . . . . . . . . . . . . . . . 3

3.3 Irradiation . . . . . . . . . . . . . . . . . . . . . . . . . . 5

4. POST-IRRADIATION EXAMINATION . . . . . . . . . . . . . . . . . . . . . . . . 7

4.1 Neutron Radiography . . . . . . . . . . . . . . . . . . . . . . . . . . 7

4.2 Gamma Scans . . . . . . . . . . . . . . . . . . . . . . . . . . . . . 7

4.3 Physical Measurements on the Fuel Cladding . . . . . . . . . . . . . . . . . . . . . 7

4.4 Fission Gas Analysis . . . . . . . . . . . . . . . . . . . . . . . . . . . 8

4.5 Fuel Burnup . . . . . . . . . . . . . . . . . . . . . . . . . . . . . 8

4.6 Fuel Swelling . . . . . . . . . . . . . . . . . . . . . . . . . . . . . 9

5. DESTRUCTIVE EXAMINATION . . . . . . . . . . . . . . . . . . . . . . . . . 12

5.1 Fuel Sectioning . . . . . . . . . . . . . . . . . . . . . . . . . . . . 12

5.2 Metallographic Examination . . . . . . . . . . . . . . . . . . . . . . . 12

6. DISCUSSION OF RESULTS . . . . . . . . . . . . . . . . . . . . . . . . . . . 29

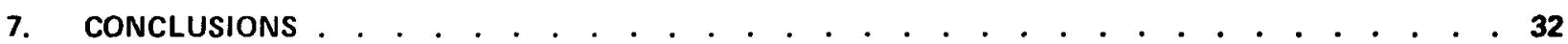

ACKNOWLEDGMENTS . . . . . . . . . . . . . . . . . . . . . . . . . . 33

REFERENCES .................................. 33

\section{APPENDICES}

A FABRICATION AND SELECT POST IRRADIATION DATA . . . . . . . . . . . . . . . . 35

B FISSION GAS CALCULATIONS . . . . . . . . . . . . . . . . . . . . . . . . . . . 41

C METALLOGRAPHY AND AUTORADIOGRAPHY RESULTS . . . . . . . . . . . . . . . 45

DISTRIBUTION . . . . . . . . . . . . . . . . . . . . . . . . 57 
-

• 


\section{LIST OF ILLUSTRATIONS}

Figure

Title

3-1 Design of Capsule . . . . . . . . . . . . . . . . . . . . . . . . . . . . . . . . 2

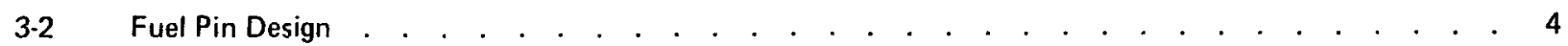

3-3 Mechanical Arrangement and Irradiation Position . . . . . . . . . . . . . . . . . . . . . . . . 5

3-4 Linear Power History . . . . . . . . . . . . . . . . . . . . . . . . . . . . . . . . . . . . . . . . 6

4-1a Gross Gamma Scan . . . . . . . . . . . . . . . . . . . . . . . . . . . . . 8

4-1b Gross Gamma Scan . . . . . . . . . . . . . . . . . . . . . . . . . . . . 9

4-2 Pellet Fuel Pin Profilometry . . . . . . . . . . . . . . . . . . . . . . . . . . . 10

4-3 Powder Fuel Pin Profilometry . . . . . . . . . . . . . . . . . . . . . . . . . . 11

5-1 Pellet Fuel Sections and Neutron Radiograph . . . . . . . . . . . . . . . . . . . . . . 13

5-2 Powder Fuel Sections and Neutron Radiograph . . . . . . . . . . . . . . . . . . . . . . . 14

5-3 Structure of Powder Fuel, Powder Fuel Section E . . . . . . . . . . . . . . . . . . . . . . . 15

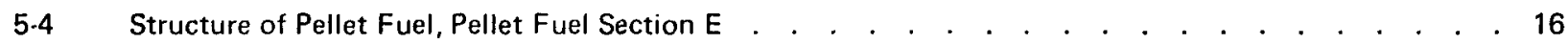

5-5 Fuel-Cladding Interface, Powder Fuel Section E . . . . . . . . . . . . . . . . . . . . . . . 17

5-6 Polished and Etched Cladding, Powder Fuel Section E . . . . . . . . . . . . . . . . . . . 18

5-7 Comparison of Powder and Pellet Fuel-Cladding Reaction at Equivalent Cladding Temperatures . . . . 19

5.8 Pellet Fuel Section E Micrographs . . . . . . . . . . . . . . . . . . . . . . . . 21

5-9 Sigma Phase in 347SS Fuel Cladding, Pellet Fuel Section E . . . . . . . . . . . . . . . . . . . 22

5-10 Electron Microprobe Specimen, Pellet Fuel Section D $\quad . \quad$. . . . . . . . . . . . . . . . . . . . . 23

5.11 Area of Fuel-Cladding Reaction Zone Examined with Electron Microprobe . . . . . . . . . . . 24

5-12 Locations of $\mathrm{Fe}, \mathrm{Ni}$ and $\mathrm{Cr}$ in the Fuel-Cladding Reaction Zone . . . . . . . . . . . . . . . . 25

5-13 Fe, Ni, and $\mathrm{Cr}$ at Selected Points in the Fuel-Cladding Reaction Zone . . . . . . . . . . . . 26

5-14 Distribution of Pd in the Fuel-Cladding Reaction Zone . . . . . . . . . . . . . . . . . . 27

5-15 Distribution of Mo, Cs, and Ba in the Fuel-Cladding Reaction Zone . . . . . . . . . . . . . . . 28

A-1 Metallography of Type 347 Stainless Steel Cladding . . . . . . . . . . . . . . . . . . 39

A-2 Axial Plot of Parameters Which May Affect Cladding Diametral Expansion . . . . . . . . . . . 40 


\section{LIST OF ILLUSTRATIONS (Continued)}

C-1 Pellet Fuel Section A . . . . . . . . . . . . . . . . . . . . . . . . . . . . 47

C-2 Pellet Fuel Section $\mathrm{H}$. . . . . . . . . . . . . . . . . . . . . . . . . . . . 48

C-3 Powder Fuel Section B . . . . . . . . . . . . . . . . . . . . . . . . . . . . 49

C-4 Powder Fuel Section B Micrographs . . . . . . . . . . . . . . . . . . . . . . . 50

C-5 Powder Fuel Section A . . . . . . . . . . . . . . . . . . . . . . . . . . . 51

C-6 Powder Fuel Section A Autoradiography . . . . . . . . . . . . . . . . . . . . . . 52

C-7 Pellet Fuel Section E and Powder Fuel Section E Autoradiography . . . . . . . . . . . . . 53

C-8 Powder Fuel Section B and Pellet Fuel Section H Autoradiography . . . . . . . . . . . . . . 54

C-9 Pellet Fuel Section A and Pellet Fuel Section G Autoradiography . . . . . . . . . . . . . . 55 
GEAP-10385

\section{LIST OF TABLES}

Table

Title

Page

3-1 Fuel Pin Design Parameters - Capsule E5B $\quad . \quad$. . . . . . . . . . . . . . . . . . . . . . . . . . 3

3-2 Capsule E5B - Linear Power . . . . . . . . . . . . . . . . . . . . . . . . . . . . 5

6-1 Thermal Irradiation Properties for Pellet and Powder Fuel Capsule E5B . . . . . . . . . . . . 30

6-2 Fission Gas Release Data from Thermal Flux Irradiations . . . . . . . . . . . . . . . . 31

6-3 Fuel Cladding Reaction Measurements . . . . . . . . . . . . . . . . . . . . . . . . 32

A-1 Fuel Impurity Analysis - Capsule E5B . . . . . . . . . . . . . . . . . . . . . . . . 35

A-2 Cladding Chemical Analysis and Mechanical Properties Data . . . . . . . . . . . . . . . 36

A-3 Relative Activity of Isotopes - Capsule E5B . . . . . . . . . . . . . . . . . . . . . 36

A-4 Fission Gas Analysis - Capsule E5B . . . . . . . . . . . . . . . . . . . . . . . . . . . . . 37

A-5 Burnup and Isotopic Distribution - Capsule E58 . . . . . . . . . . . . . . . . . . . . 38 
-

○ 


\begin{abstract}
The performance at high burnup ( 148,000 MWd/Te) of powder and pellet mixed-oxide fuel was investigated. Fuel-cladding reaction resulted in the uniform loss of 0.003 to 0.004 inch of 347 stainless steel from the inside surface of the cladding at inside surface temperatures in excess of $1300^{\circ} \mathrm{F}$ for both types of fuel. Nonuniform cladding attack of 0.005 inch was observed in the pellet pin.
\end{abstract}

\title{
1. SUMMARY
}

An irradiation experiment was conducted to determine the operating characteristics of vibratory-compacted and pellet mixed-oxide fuel under burnup, linear power, and cladding temperature conditions typical of, or higher than, those expected in advanced LMFBR's. This experiment was conducted in a thermal flux and consisted of two axially aligned fuel pins of 0.250 -inch diameter. The pins were clad with type 347 stainless steel and contained $\left(\mathrm{Pu}_{0.25} \mathrm{U}_{0.75}\right) \mathrm{O}_{2.00}$ fuel of $84 \%$ theoretical density. The pins were irradiated simultaneously at $23.5 \mathrm{~kW} / \mathrm{ft}$ to a peak burnup of $149,000 \mathrm{MWd} / \mathrm{Te}$. Cladding temperatures were in excess of $1300^{\circ} \mathrm{F}$.

Post-irradiation examination showed that while both pins were intact, there was general attack on the inside surface of the cladding. Cladding reactions of up to 5 mils were observed in regions where the cladding operated at temperatures between $1300^{\circ}$ and $1400^{\circ} \mathrm{F}$. Regions of the fuel pins that operated at temperatures of $1200^{\circ} \mathrm{F}$ exhibited cladding attack of approximately 1 mil. Electron microprobe examinations of the reacted regions indicated the presence of $\mathrm{Pd}, \mathrm{Mo}, \mathrm{Cs}$, and Ba.

Maximum fuel pin diametral changes of $1.2 \%$ and $0.7 \%$ were observed for the pellet and powder fuel, respectively. Center fuel melting occurred in both pins in this test and this condition is believed to be partially responsible for the observed diametral change. Best measurements of the pre-and-post-irradiation fuel volumes indicate that the fuel swelled at a rate of approximately $0.28 \% \Delta V / V$ per $10^{20} \mathrm{f} / \mathrm{cc}$. Examination of the fuel microstructures showed that thermal performance of the two fuels was equivalent at high fuel burnup. Fission gas release fractions of $91 \%$ and $78 \%$ were calculated for the pellet and powder fuel, respectively.

\section{INTRODUCTION}

The experimental results of a thermal flux test carried out to explore the performance of pellet and powder mixed-oxide fuels at peak cladding temperatures of $1400^{\circ} \mathrm{F}$ are described in this report.

The fabrication method for fast reactor fuels must be optimized to satisfy both performance requirements and low fabrication costs. Sintered pellet and vibratory-compacted powder fuel are two potential fabrication methods but their relative merits regarding applications to fast reactor technology remain uncertain. The objective of this experiment was to obtain performance data for these two fuel types under operating conditions typical of advanced LMFBR's. A second objective of this experiment was to establish the stability of type $\mathbf{3 4 7}$ stainless steel cladding in contact with mixed-oxide fuel at temperatures up to $1400^{\circ} \mathrm{F}$.

The fuel pins for this test contained fuel of the same initial smear density ( $84 \%$ of theoretical) and the maximum exposure attained was about 149,000 MWd/te. Information was obtained on (1) cladding deformation, (2) fuel swelling, (3) fuel redistribution, (4) fuel-cladding reaction, (5) fission-gas release, and (6) the thermal performance of both types of fuel.

\section{DESCRIPTION OF EXPERIMENT}

\subsection{IRRADIATION CAPSULE DESIGN}

The test capsule was designed to permit simultaneous irradiation of two fuel pins under similar conditions. The capsule design is shown in Figure 3-1. Two 0.250-inch diameter fuel pins were positioned one above the other in the capsule. The irradiation was performed in the General Electric Test Reactor (GETR) using a vertical and radially adjustable facility tube (V-RAFT). ${ }^{2}$ The use of this facility permitted the irradiation of both pins at a constant power level.

* The results of a companion test (E5A) to determine the short-term performance of solid pellet and powder fuel have been reported previously. 1 

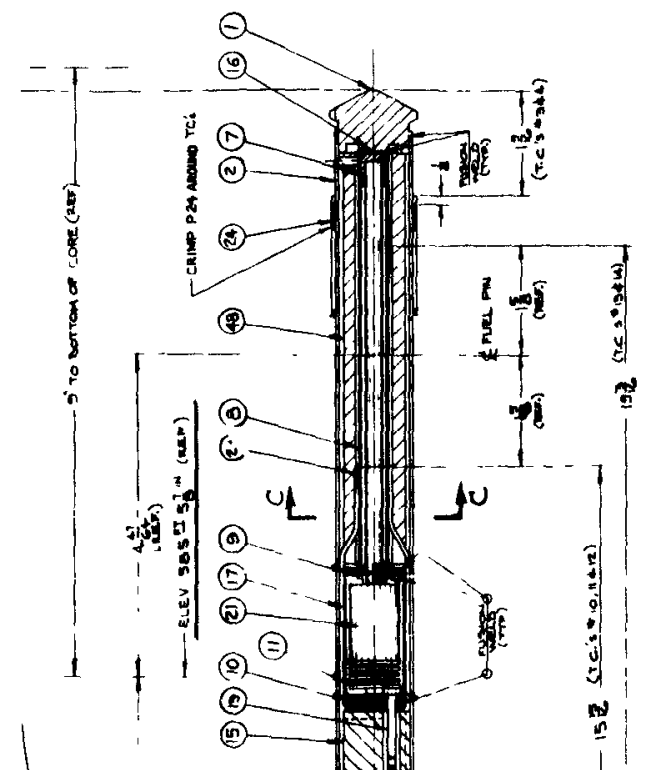

敕

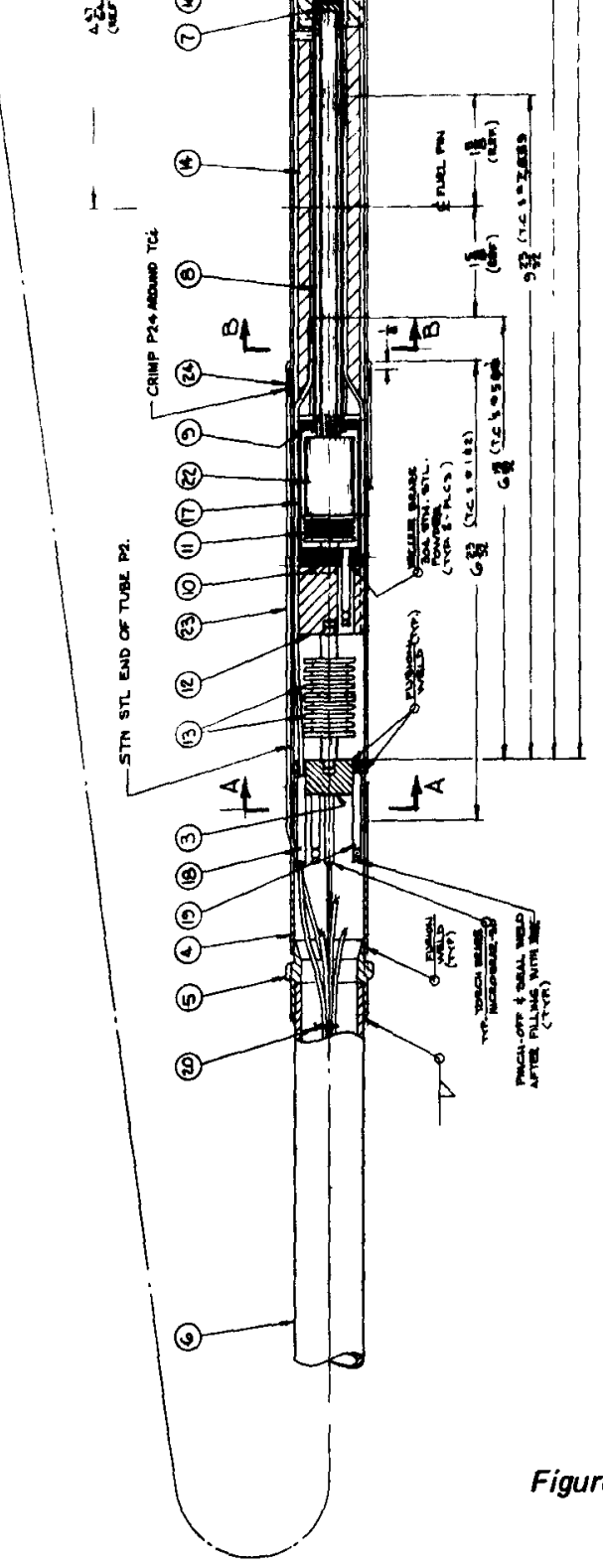

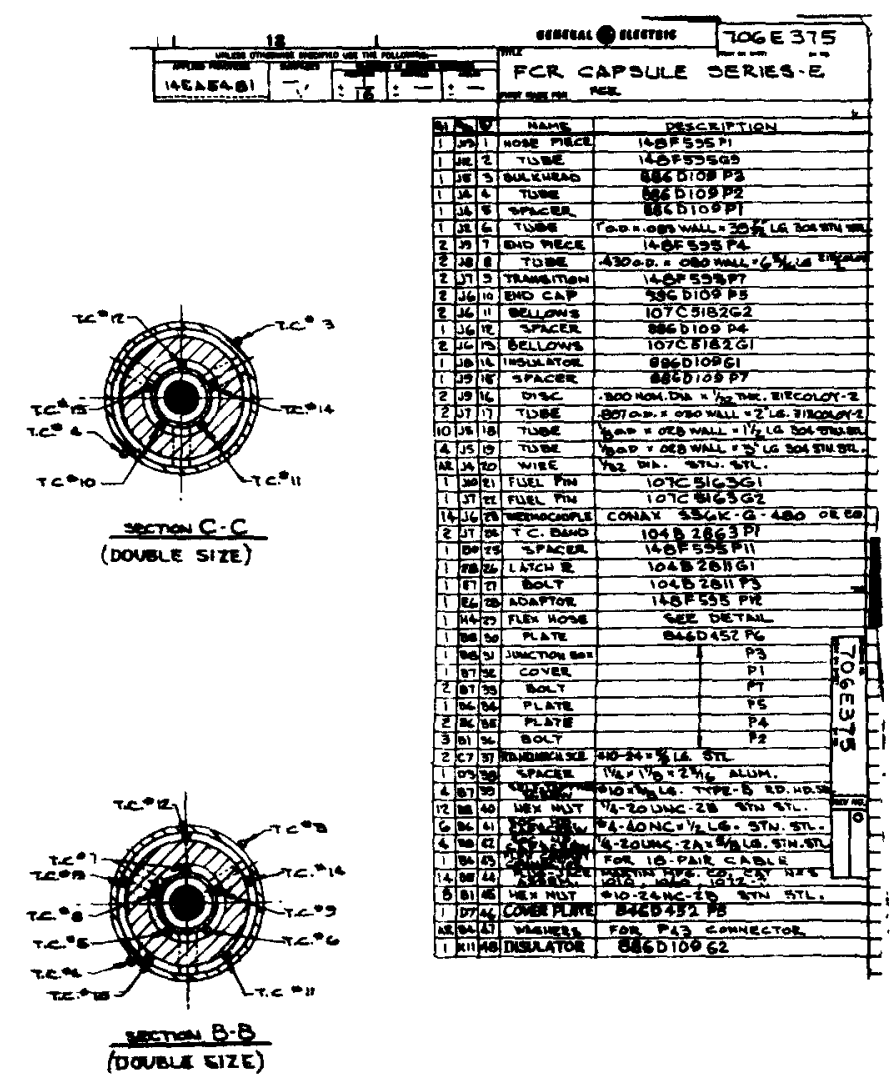

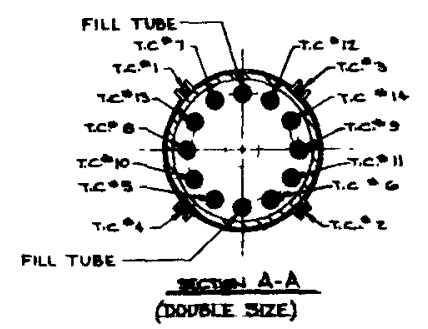

(가) $e-\mathbf{x}-\mathbf{B}$ 
The pins were individually encapsulated to prevent the malfunction of one pin from affecting the operation of the other. Another design feature of the capsule was the use of bellows to accommodate the thermal expansion of the $\mathrm{NaK}$ thermal bond. This design significantly decreased the possibility of entrapment of gas bubbles in the NaK heat transfer medium which could result in hot spots and subsequent fuel pin failure.

Temperatures were measured radially and axially in the capsule by chromel-alumel thermocouples. These thermocouples were used to monitor the operation of the capsule and to determine the operating power.

\subsection{FUEL PIN DESIGN}

The fuel and cladding parameters are listed in Table 3-1. Ceramic grade powder was prepared by the co-precipitation process. High-density granules suitable for vibratory compaction were prepared by a pre-press and granulation process. ${ }^{3}$

The fuel pin design is shown in Figure 3-2. After loading, each fuel pin was backfilled with helium at one atmosphere and welded.

\section{TABLE 3-1}

FUEL PIN DESIGN PARAMETERS - CAPSULE E5B

Fuel

Type

Composition

O/M Ratio

$\%$ U-235/U

Length, In.

Smeared Density, \%

Pellet Density, \%

Pellet Diameter, in.

Diametral Fuel-Clad Gap, in.

Insulators

Density, \%

Pellet Diameter, in.

Fuel Cladding

Type

o.d., in.

Wall, in.

i.d., in.
E5B-1

E5B-2

Solid Pellet

$$
\left(\mathrm{PU}_{0.25} \mathrm{U}_{0.75}\right) \mathrm{O}_{2.00}
$$$$
1.999-2.000
$$

40

4.87

4.88

$83.5 \cdot 85.1$

84.1

$85.2-86.8$

0.2164-0.2183

0.0020-0.0039

$\cdots$

$\cdots$

0

$\mathrm{UO}_{2}$

95.0

82.0

0.2165

Welded and Drawn

347 SS

0.251 Nom.

0.015 Nom.

$0.2203 \pm 0.0001$

$-3-$ 


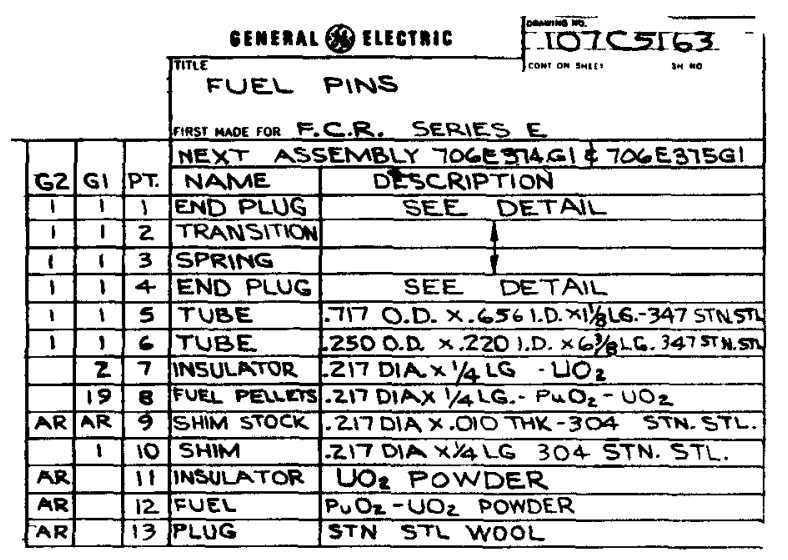

REF.

F.CR. FUEL PINS E.II-CIEC2 IOTC5133

USE IGTAITOB FOR FDEL LOADING.

2. FUEL PIN FAB. SPEC. 21-A-4954.

1. DEGREASE ALL PARTS.

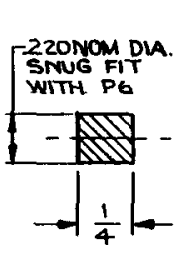

(1) $347 \mathrm{STN} \mathrm{STL}$

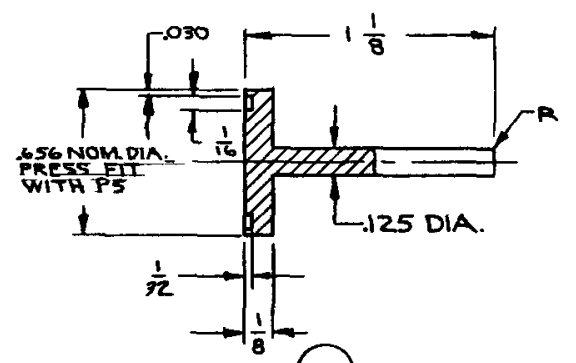

(4) 347 STN. STL. NOTES:

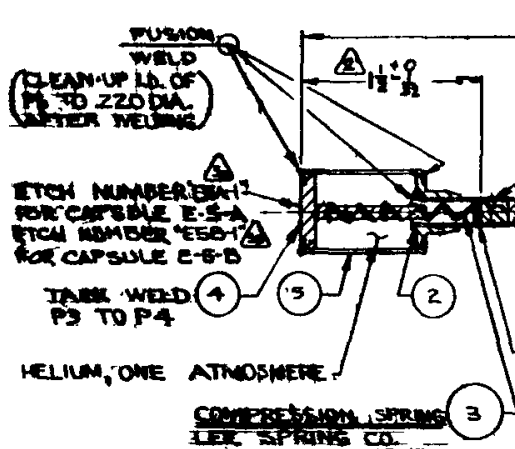

$7 \frac{3}{8}$

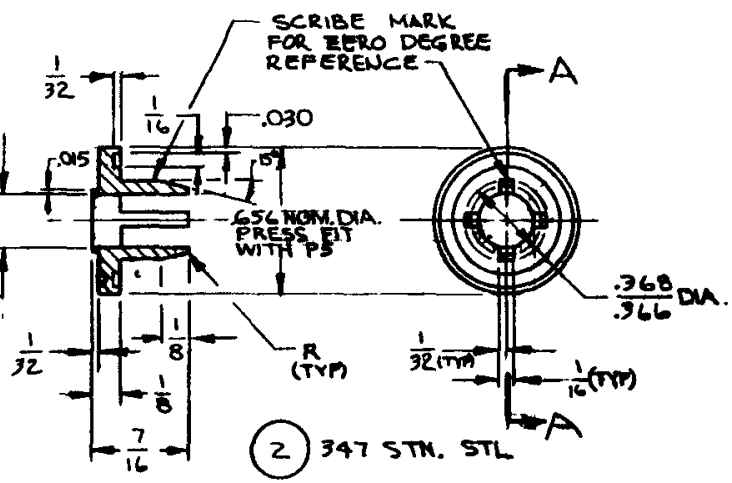

SECTIONA-A

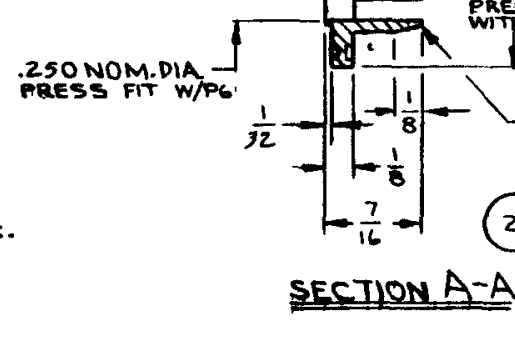

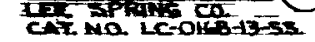

$4 \frac{3}{4}$

(Mef)
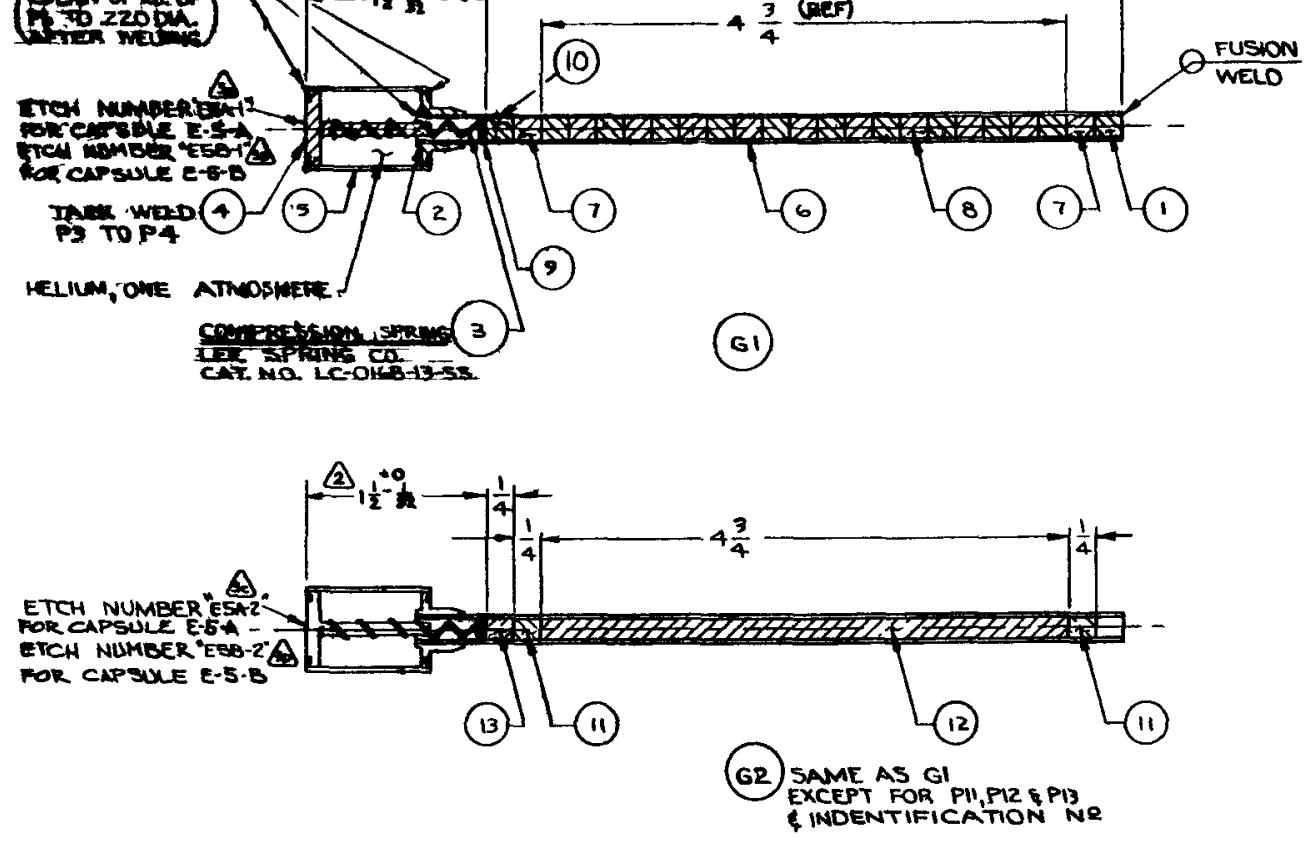

Figure 3-2 Fuel Pin Design 
Chemical analysis for the fuel and cladding are listed in Table A-1 and A-2, (Appendix A). Pre-irradiation cladding metallography is shown in Figure A-1.

\subsection{IRRADIATION}

The capsule was irradiated for 349 effective full power days (EFPD) at a peak power of $23.5 \mathrm{~kW} / \mathrm{ft}$ and was subjected to 87 thermal cycles. Figure 3-3 illustrates the relative location of the fuel in the neutron flux. Maximum and average axial flux profiles are shown.

The capsule power history is shown in Figure 3-4. Peak operating power was approached on a ramp at the beginning of the irradiation to allow sufficient time for restructuring of the fuel.

Several methods were used to determine capsule operating power. These were (1) thermal dam thermocouples, (2) water calorimetry, (3) reactor physics calculations, and (4) fuel burnup analysis. The powers determined by these methods are listed in Table 3-2. During the irradiation the thermal dam thermocouple readings were used to control the capsule power.

TABLE 3-2

CAPSULE E5B - LINEAR POWER

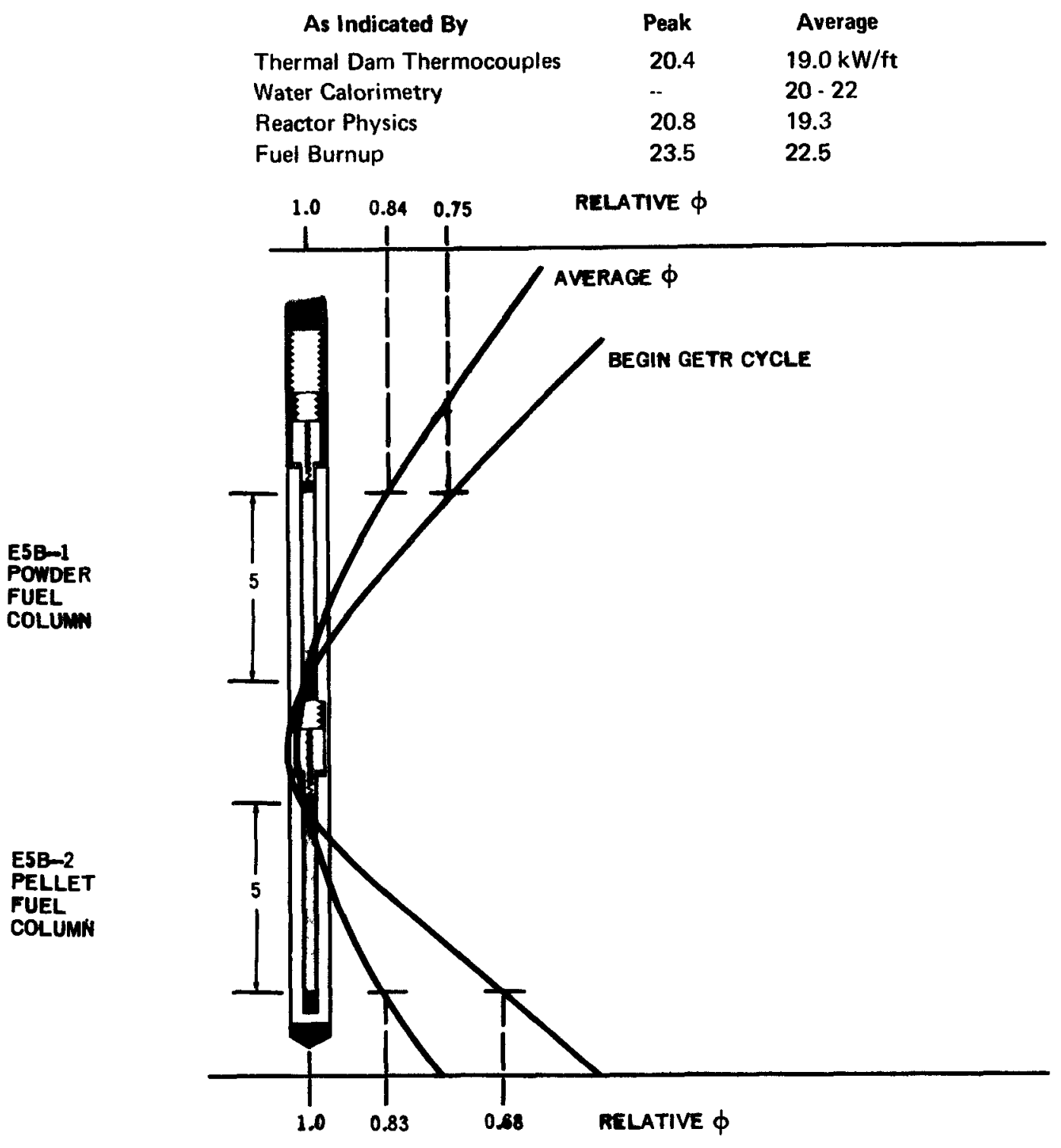

Figure 3-3 Mechanical Arrangement and Irradiation Position 
GEAP-10385

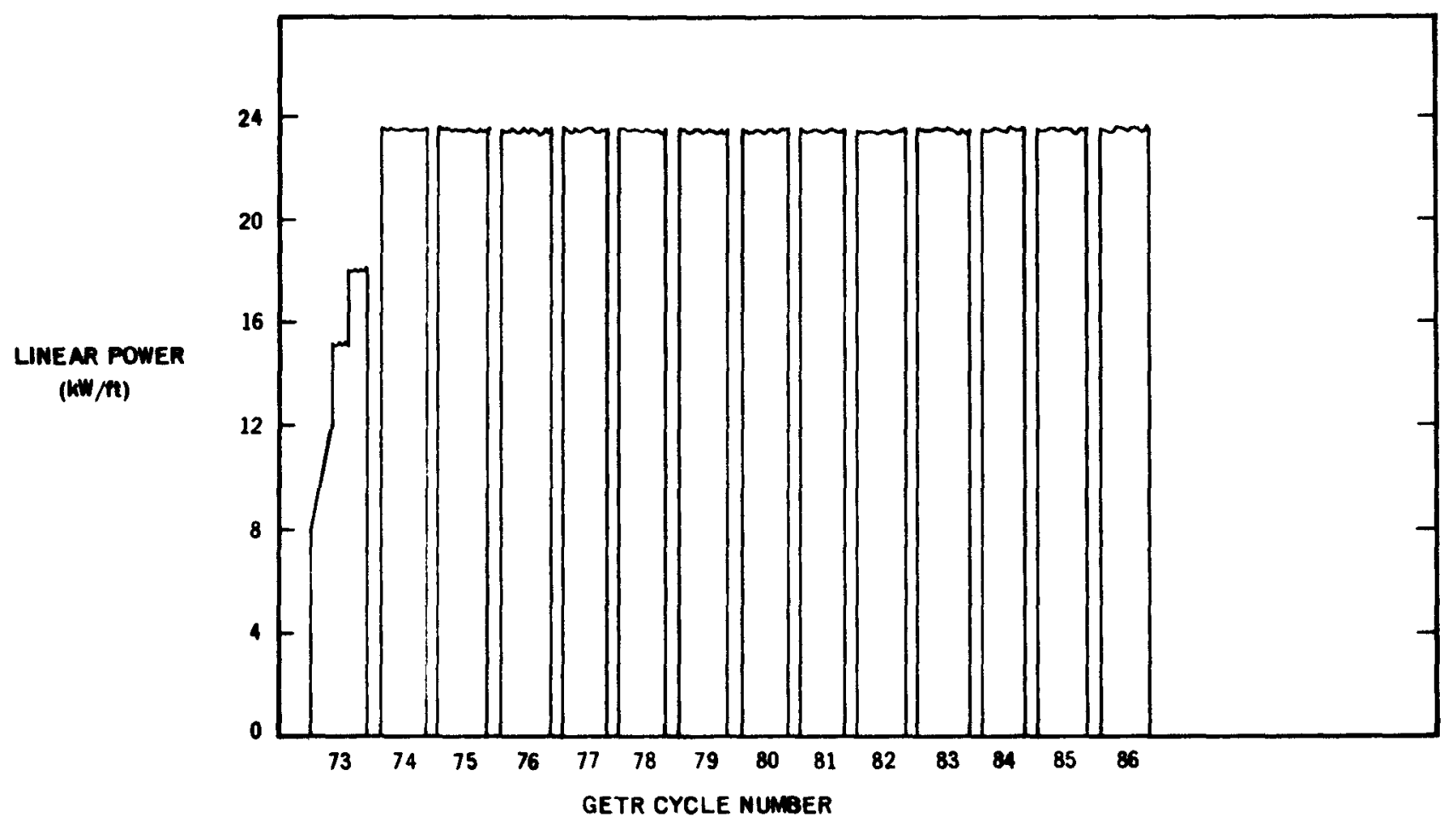

Figure 3-4 Linear Power History 


\section{POST-IRRADIATION EXAMINATION}

\subsection{NEUTRON RADIOGRAPHY}

Neutron radiographs of the capsule were taken at the end of the irradiation. These radiographs indicated that the fuel pins were intact and that some fuel melting had occurred in both pins. In addition, in the pellet fuel pin the center void was observed to be closed in at least two locations. Subsequent metallographic examinations of these areas indicated that a fuel bridge, within the center void, did exist in two locations. Several unsuccessful attempts were made to establish the pellet interfaces by neutron radiography. The results of these radiographs indicated that at high burnups and temperatures the identification of individual pellet interfaces is lost.

\subsection{GAMMA SCANS}

Gamma scans were taken of the capsule prior to the destructive examination. The following energy levels were discriminated:

1. $>0.670 \mathrm{MeV}$ for gross scan

2. $\quad 0.513 \mathrm{MeV}$ for Ru-106

3. $\quad 0.764 \mathrm{MeV}$ for $\mathrm{Zr}-\mathrm{Nb}-95$

4. $\quad 1.600 \mathrm{MeV}$ for Ba-La-140

A gross gamma scan of the capsule is shown in Figure 4-1.

In the pellet fuel pin gamma activity peaking at points $2 D, 2 E, 2 F$, and $2 G$, as shown in Figure 4-1, corresponded to the location of fuel bridges observed in the neutron radiograph.

In the powder fuel, destructive examination showed that the high gamma activity area (1F) at the bottom of the pin resulted from filling of the central void with molten fuel. The points identified on Figure 4-1 were scanned to determine the gamma intensity of specific isotopes. These results are tabulated in Appendix A, Table A-3. These data indicated that the fuel bridge regions exhibited high Ba-La-140 activity.

\subsection{PHYSICAL MEASUREMENTS ON THE FUEL CLADDING}

Physical measurements were performed on the fuel pins prior to their destructive examination. The appearance of the cladding was similar to unirradiated control samples and no effect from the high temperature NaK environment was observed. Decay heat kept the cladding surface at a temperature in excess of $220^{\circ} \mathrm{F}$ during the examination and some darkening occurred during prolonged exposure to air.

Profilometer measurements showed maximum diametral increases of $1.2 \%(0.0030 \mathrm{in}$.$) for the pellet fuel cladding$ and $0.7 \%(0.0017 \mathrm{in.})$ for the powder fuel cladding. Axial profile measurements were made at 0-, 45- and 90-degree orientations and a helical trace was obtained with the specimens rotating. Profilometer traces are shown in Figures 4-2 and 4-3.

Diametral increase was nonuniform over the length of the pellet fuel cladding. The helical trace indicated a maximum ovality of 0.006 inch. The two areas of maximum ovality corresponded to the axial location of maximum strain on the 45- and 90-degree traces. Diameter reductions of up to 0.001 inch were observed on the 0 -degree trace. The large ovality in the pellet fuel cladding indicates that most of the diameter increase resulted from cladding distortion rather than diametral strain. The maximum ovality measured on the powder fuel cladding was 0.002 inch. No reduction in diameter similar to that observed on the $\mathbf{0}$-degree trace of the pellet fuel pin was found.

Fuel pin diametral expansion showed no correlation with fuel-cladding gap or fuel density. Axial plots of these parameters for the pellet pin are shown in Appendix A, Figure A-2. irradiation.

Length measurements on both fuel pins indicated that no significant change in fuel pin length occurred during 


\subsection{FISSION GAS ANALYSIS}

Following collection of the helium-fission gas mixture it was determined that the pellet fuel released $99 \mathrm{cc}$ of fission gas and the powder fuel released $84 \mathrm{cc}$. Fractional releases of $91 \%$ (pellets) and $78 \%$ (powder) were calculated using the gas chromatography data*. Aliquots of the fission gas were analyzed by gas chromatography, gamma counting, and mass spectrometer. The results of these analyses are shown in Appendix A, Table A-4. Fission gas calculations are contained in Appendix B-1.

\subsection{FUEL BURNUP}

Burnup analysis was performed by mass spectrometry on two samples from each fuel column. Both the heavy element ratio and neodymium 148 to heavy element ratio techniques were used. ${ }^{4}$ The results of these analyses indicated that the peak power in the fuel was $15 \%$ higher than had been estimated by GETR physics and heat transfer

* A second calculation utılızıng Kr-85 gamma countıng vielded values of $100 \%$ (pellets) and $122 \%$ (powder). These values were considered in error because of the higher than theoretical release rate.

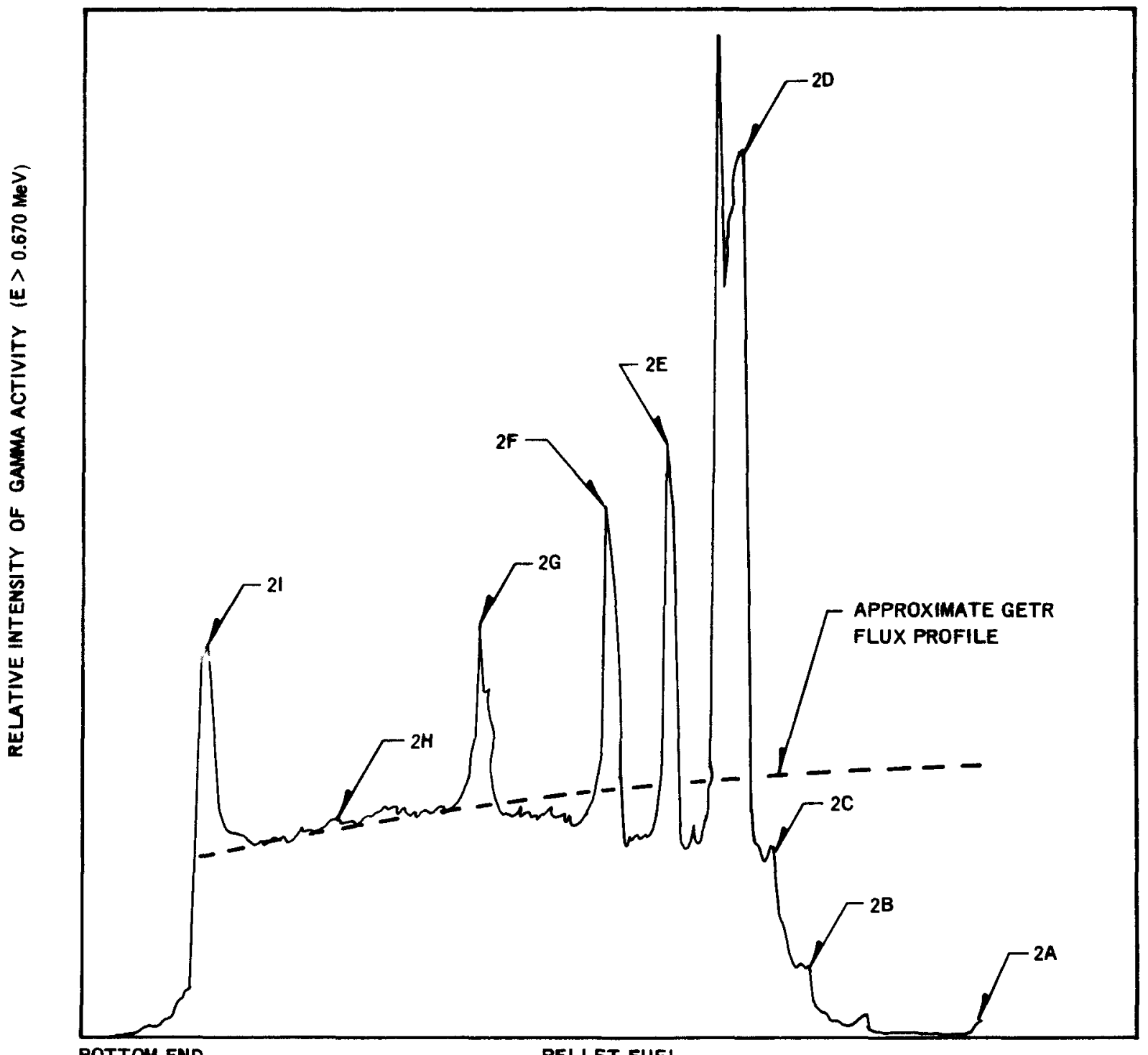


calculations. Isotopic contents of the fuel before and after irradiation are given in Appendix A, Table A-5, with the results of the burnup analysis. Burnups based on neodymium 148 to heavy element ratio for the high power ends of the fuel columns differ by $21,000 \mathrm{MWd} / \mathrm{Te}(159,000$ versus 138,000$)$. Subsequent post-irradiation examination of the specımen utilized for burnup analysis in the peak power region of the pellet pin indicated that this section (section $H$ $159,000 \mathrm{MWd} / \mathrm{Te}$ ) contained a large central void whıle the powder fuel specımen (section $\mathrm{B}, 138,000 \mathrm{MWd} / \mathrm{Te}$ ) did not. Flux depression calculations showed that the difference in linear power in these highly enriched fuels would be less than $1 \%$ when both were exposed to the same thermal neutron flux. Because of the flux depression, the fuel in the center of the powder specimen was of low burnup which tended to depress the average burnup value. The pellet specimen contained no fuel in the central area and this tended to enhance the burnup value. Therefore the discrepancy in the reported burnups is believed to have resulted from a physical difference in the fuel sample geometry rather than from the fuels operatıng at different power levels. After consıderıng these factors it was decided that the average of the two burnups was the more realistıc value $(149,000 \mathrm{MWd} / \mathrm{Te})$. On this basis, the peak power was calculated to be 23.5 $\mathrm{kW} / \mathrm{ft}$.

\subsection{FUEL SWELLING}

Fuel column length increases of $8 \%$ (pellet) and $3 \%$ (powder) were measured from neutron radiographs and were confirmed during the destructive examınatıon. These values, along with the post-irradıation diameter measurements, were utılızed in estımatıng fuel swellıng. These calculations showed that the fuel occupıed less volume ${ }^{*}$ after irradıatıon than before for both the powder and pellet pın. On this basis the pellet fuel occupied $96.4 \%$ of the pre-irradiated volume and the powder fuel occupied $95.8 \%$. This result indicates that fuel densification exceeded fission product swelling by $3 \%$ to $4 \%$. This is reasonable since the initial fuel density was only $84 \%$ and the linear power of this experıment was high enough to cause gross sintering in situ.

* Fuel volume used in these calculations included internal fuel porosity minus the volume of the central void.

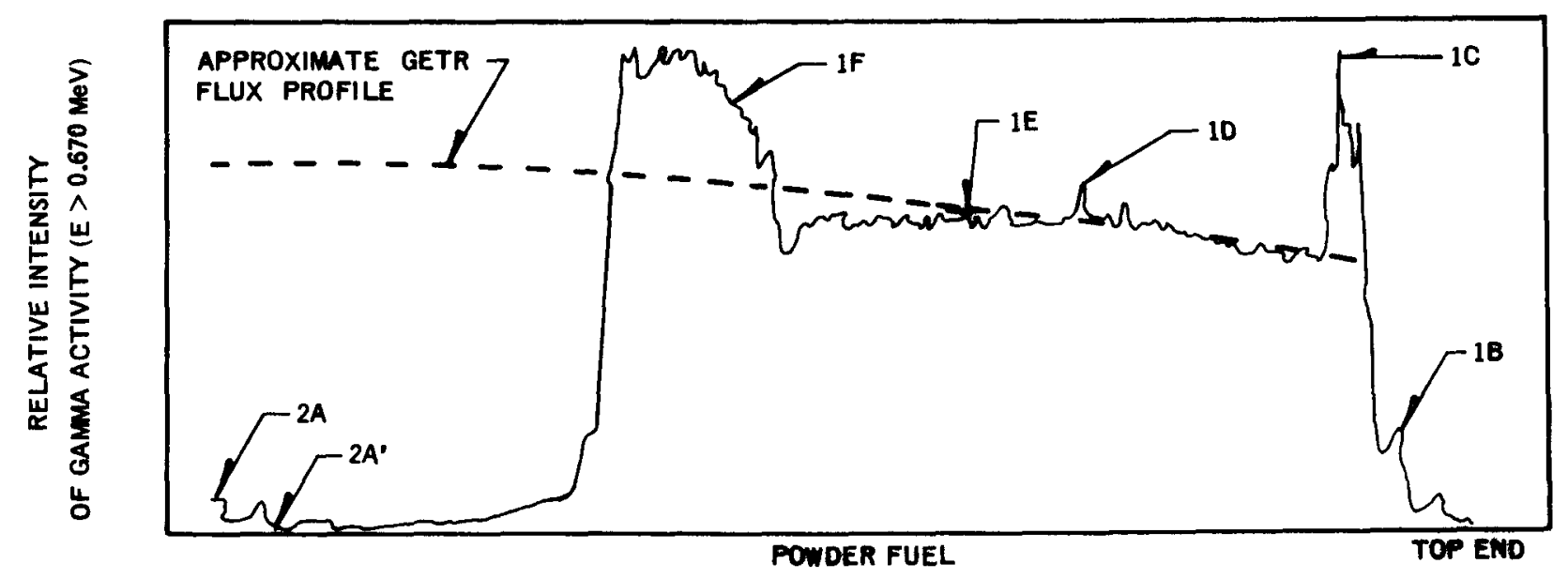

Figure 4.1b Gross Gamma Scan 


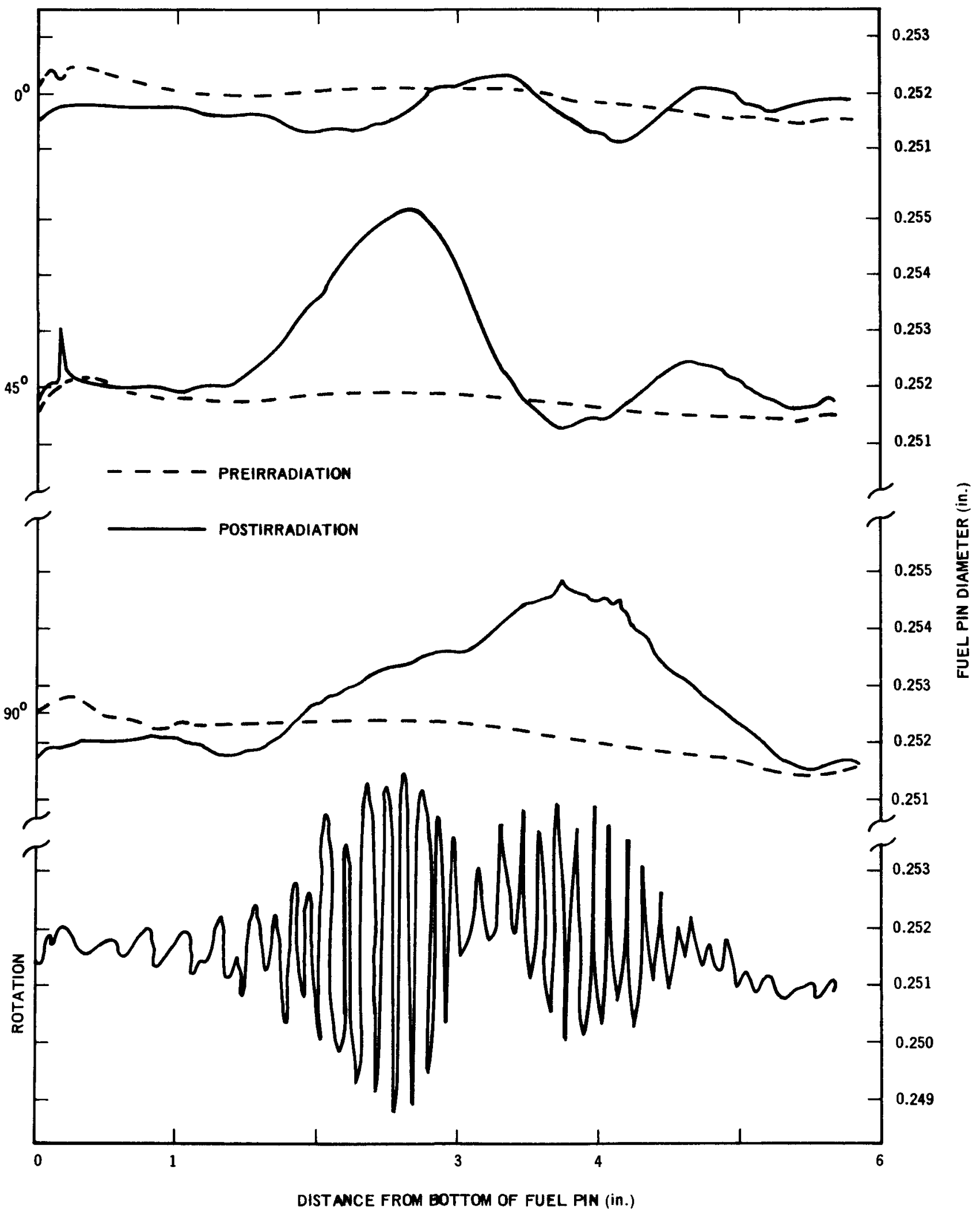

Figure 4-2 Pellet Fuel Pin Profilometry 


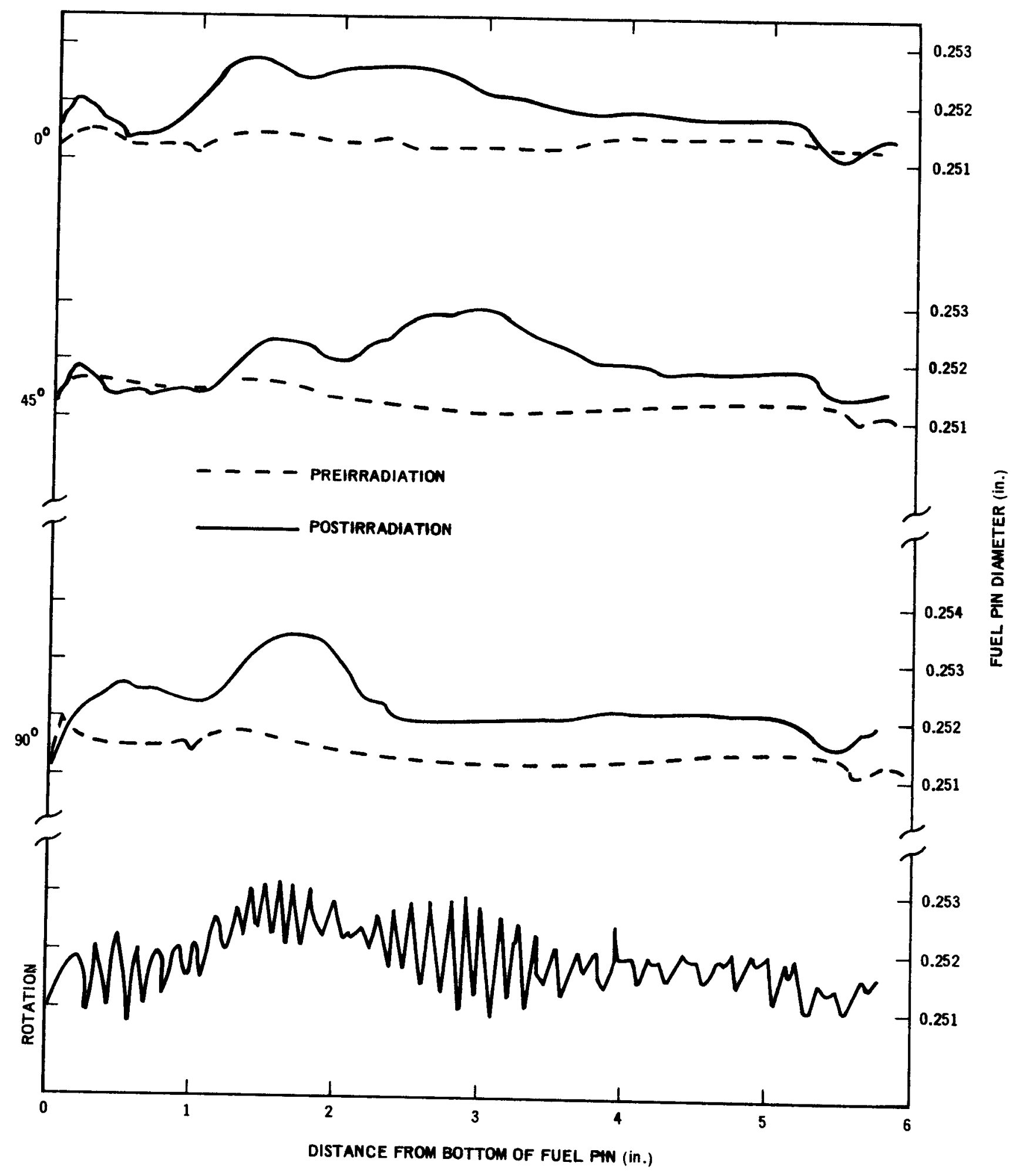

Figure 4-3 Powder Fuel Pin Profilometry 


\section{DESTRUCTIVE EXAMINATION}

\subsection{FUEL SECTIONING}

The fuel pins were sectioned into specimens $1 / 2$ inch to 5/8 inch in length. Macrographs were taken at both ends of each section and typical macrographs are shown with neutron radiographs in Figures 5-1 and 5-2.

Fuel bridges are visible in the central void of the pellet fuel in sections $C, E, F$, and G, Figure 5-1. The central void volume was only $3 \%$ at the bottom (low power) end of the pin and increased to $28 \%$ at the upper end of the pin.

Near the bottom (high power) end of the powder fuel no central void existed. Subsequent metallographic examination revealed a molten core in this region. Above this molten core two small spheres of fuel were found in the central void (see macrograph C, Figure 5-2). These spheres had a glassy appearance and were firmly attached to the wall of the void.

\subsection{METALLOGRAPHIC EXAMINATION}

Figures 5-3 and 5-4 show comparable sections from near the axial center of the powder and pellet fuel (E sections of Figures 5-1 and 5-2). No fuel melting occurred in these areas and these sections are estimated to have operated under equivalent conditions of power and burnup. For this reason they were used in making performance comparisons of the powder and pellet fuel. A description of these specimens is given below.

\subsubsection{Description of Comparable Sections of Powder and Pellet Fuels} Irradiation Conditions:

Linear Power

Fuel Center Temperature

Fuel Surface Temperature

Cladding Inside Surface Temperature

Central Void Volume

\author{
$22.5 \mathrm{~kW} / \mathrm{ft}$ \\ $2600^{\circ} \mathrm{C}$ \\ $1230^{\circ} \mathrm{C}$ \\ $721^{\circ} \mathrm{C}\left(1330^{\circ} \mathrm{F}\right)$ \\ Powder 9.5\%; Pellets 10.3\%
}

The central void in powder fuel section E (Figure 5-2) occupied 9.5\% of the fuel area with the columnar grains extending to $80 \%$ of the fuel radius. Equiaxed grains of decreasing size extended to $90 \%$ of the fuel radius. The fuel between the equiaxed grains and the cladding was extremely porous. Pore sizes up to 0.0015 inch in diameter were measured (see Figure 5-5). Fission gas probably formed the majority of these pores but some may have contained metallic fission products which were lost during metallographic preparation. In contrast, the porosity and metallic fission products contained in the region of equiaxed grain growth were generally less regular in form and appeared to follow the grain boundaries. Metallic fission products were dispersed throughout the fuel but the greatest concentration was observed in the area of equiaxed grain growth. Stringers of white metallic fission products were visible within radial cracks. Some of these extended from the cladding through the equiaxed grain region. Metallic fission products in the region of collumnar grain growth were spherical, probably as a result of surface tension effects since they were molten during irradiation.

A band of second phase material about 0.001 inch thick was located between the fuel and cladding, Figure 5-5. Although a distinct boundary existed between this material and the cladding, it is believed that this band resulted from cladding reaction rather than fission-product deposition. The inner 0.003 to 0.004 inch of the cladding showed an affected zone with distinguished grain boundaries. A light oxalic acid electrolytic etch was sufficient to remove both the band of material between the fuel and cladding and also the material within the grain boundaries of the affected zone in the cladding (see Figure 5-5). Additional etching produced the cladding structure shown in Figure 5-6*. Metallic fission products in the adjacent fuel were not affected by the etch. Intergrannular precipitation of carbides in the cladding was observed in all cross sections. Regions adjacent to the affected zone exhibited both intergrannular and intragrannular precipitates.

The fuel morphology in pellet fuel section E, shown in Figure 5-4, was generally similar to that of the equivalent powder fuel specimen previously described. The central void occupied $10.3 \%$ of the fuel area, with columnar grains extending to $83 \%$ and equiaxed grains of decreasing size extending to $93 \%$ of the fuel radius. Comparable micrographs of the pellet and powder fuel adjacent to the cladding are shown in Figure 5-7.

* The voids in the etched cladding sample (Figure 5-6) were subsequently determined to represent locations of sigma phase removed by the oxalic acid etch. Specimens etched with Villelas reagent confirmed this observation (see Figure 5-9). 


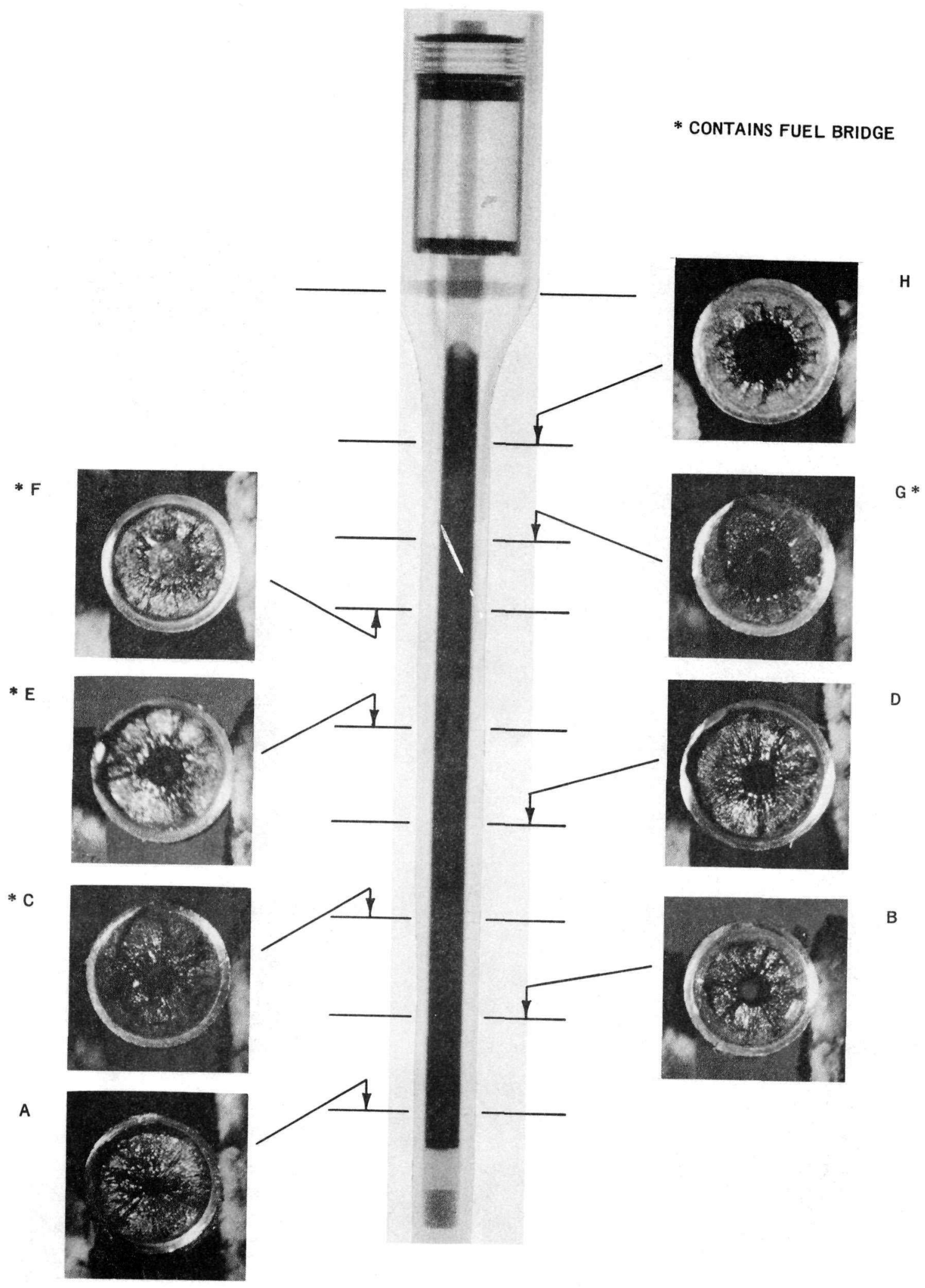

PELLET FUEL

Figure 5-1 Pellet Fuel Sections and Neutron Radiograph 
GEAP-10385

G

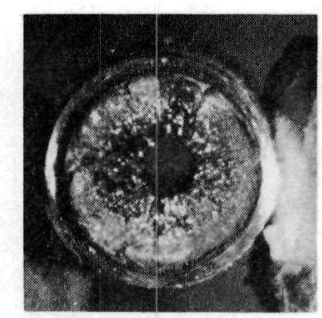

D

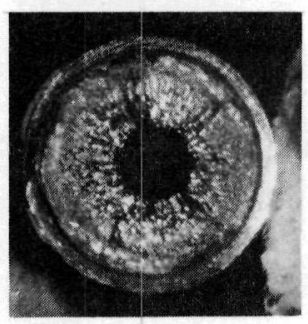

C

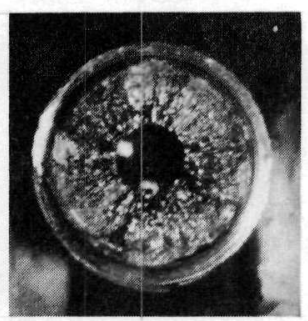

A

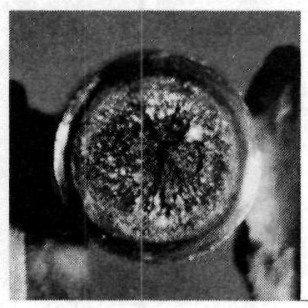

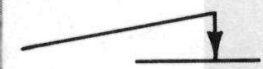
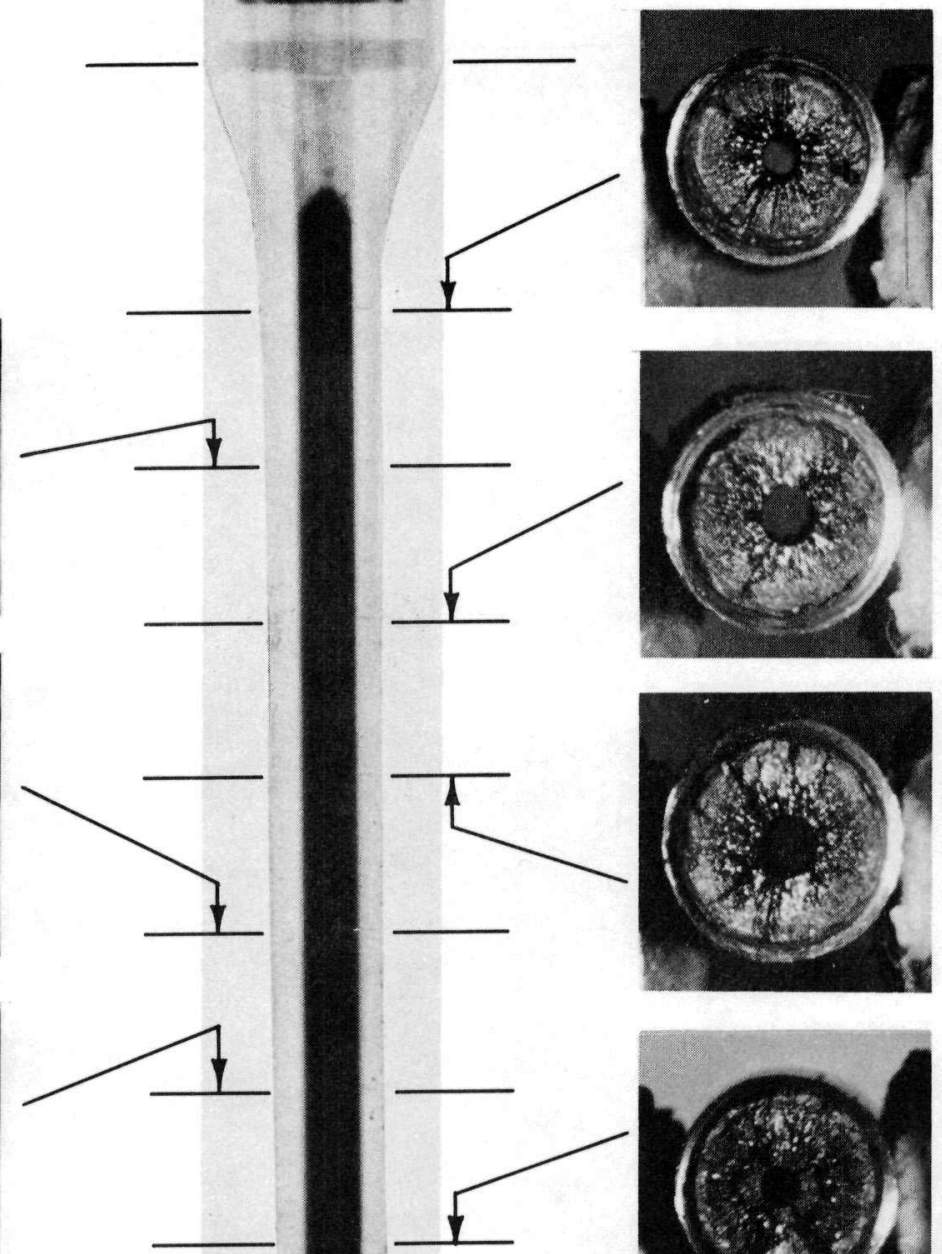

H

$\mathrm{F}$

E

B

POWDER FUEL

Figure 5-2 Powder Fuel Sections and Neutron Radiograph 


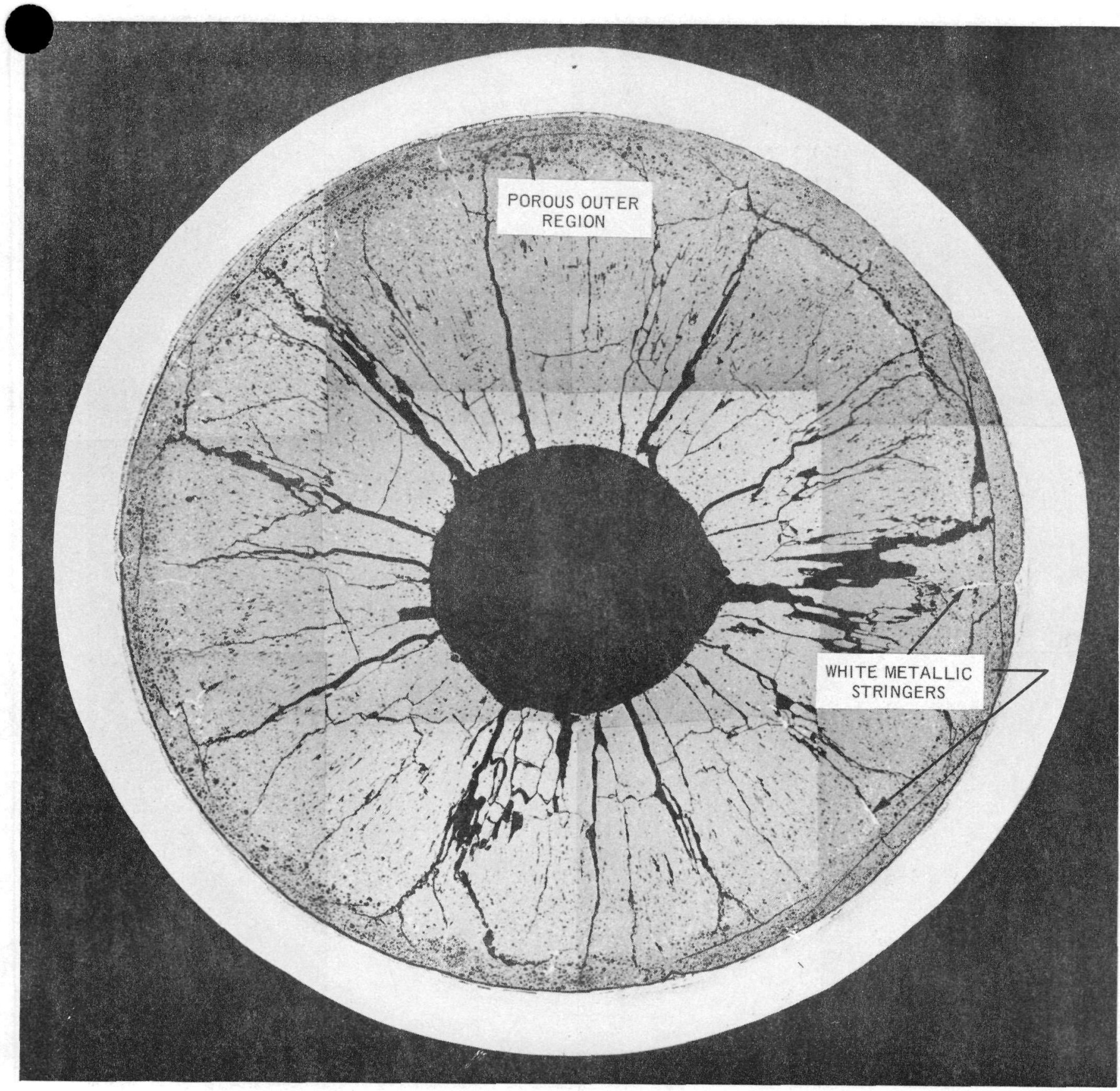

POWDER FUEL, SECTION E

$30 x$

LINEAR POWER

FUEL CENTER TEMPERATURE

FUEL SURFACE TEMPERATURE

CLAD INSIDE SURFACE TEMPERATURE

VOID VOLUME
$22.5 \mathrm{~kW} / \mathrm{ft}$

$2600^{\circ} \mathrm{C}$

$1230^{\circ} \mathrm{C}$

$720^{\circ} \mathrm{C}\left(1330^{\circ} \mathrm{F}\right)$

$9.5 \%$

Figure 5-3 Structure of Powder Fuel, Powder Fuel Section E 


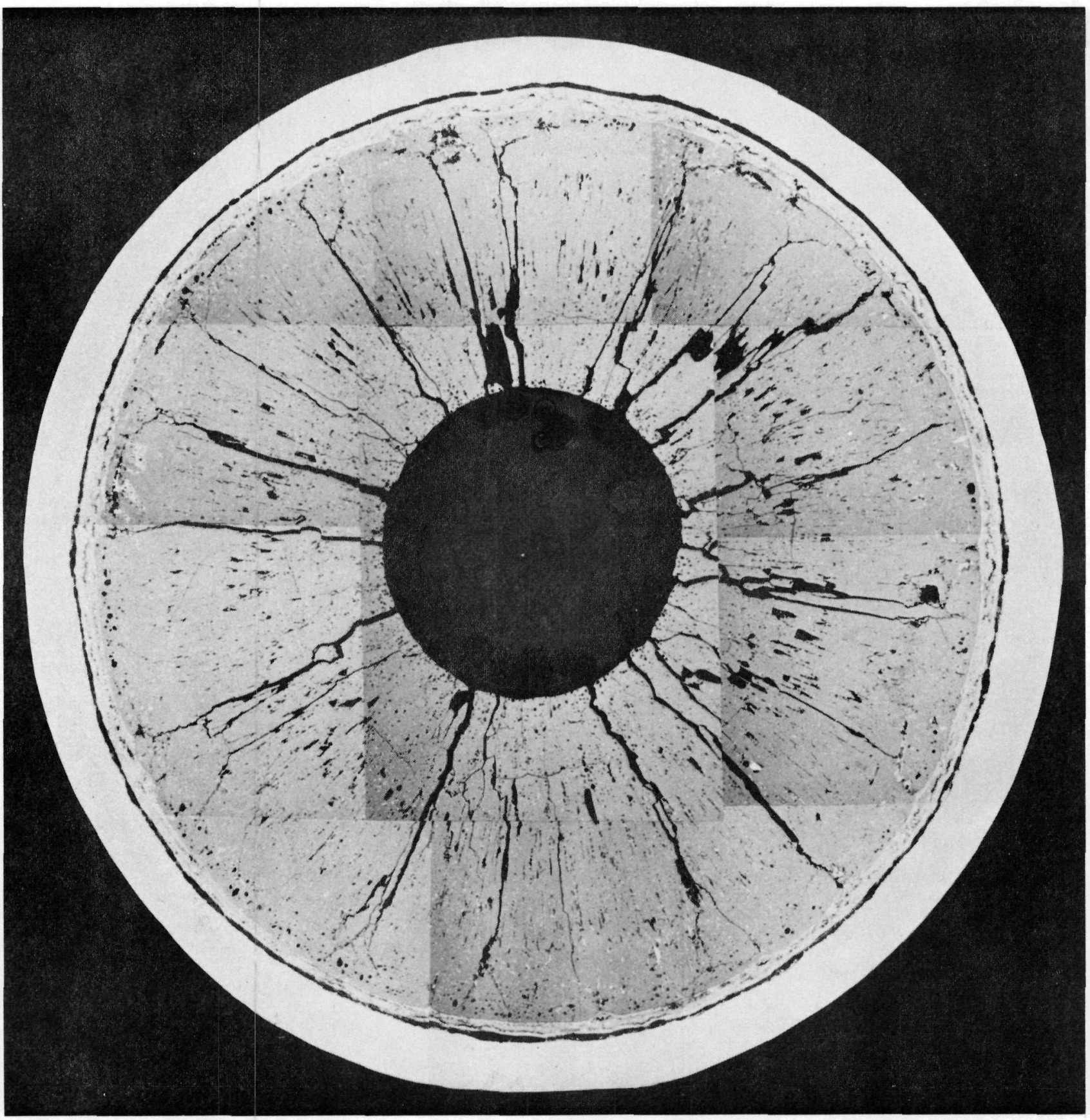

PELLET FUEL, SECTION E

LINEAR POWER

FUEL CENTER TEMPERATURE

FUEL SURFACE TEMPERATURE

CLAD INSIDE SURFACE TEMPERATURE

VOID VOLUME
$22.5 \mathrm{~kW} / \mathrm{ft}$

$2600^{\circ} \mathrm{C}$

$1220^{\circ} \mathrm{C}$

$720^{\circ} \mathrm{C}\left(1330^{\circ} \mathrm{F}\right)$

$10.3 \%$

Figure 5-4 Structure of Pellet Fuel, Pellet Fuel Section E 

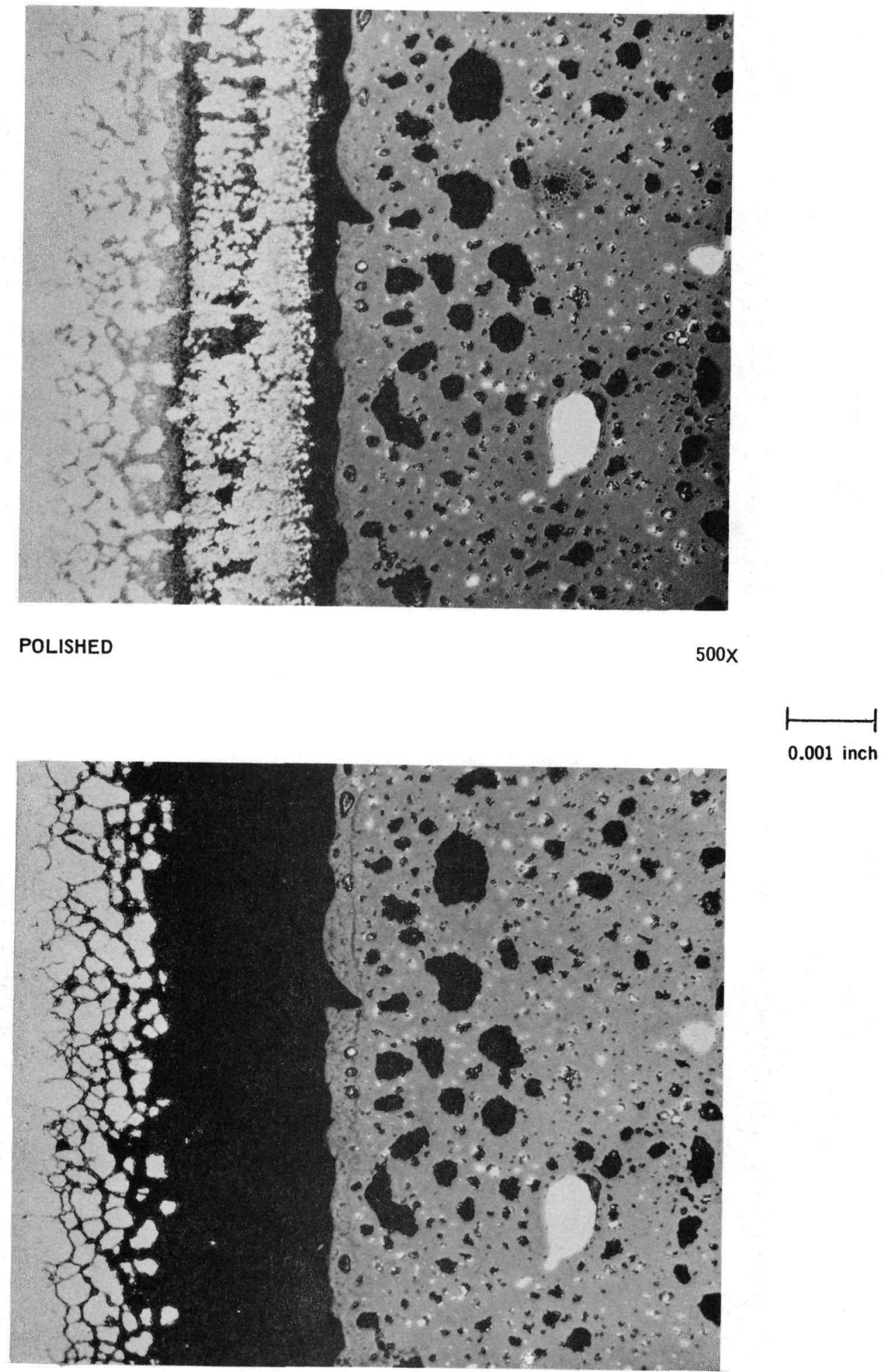

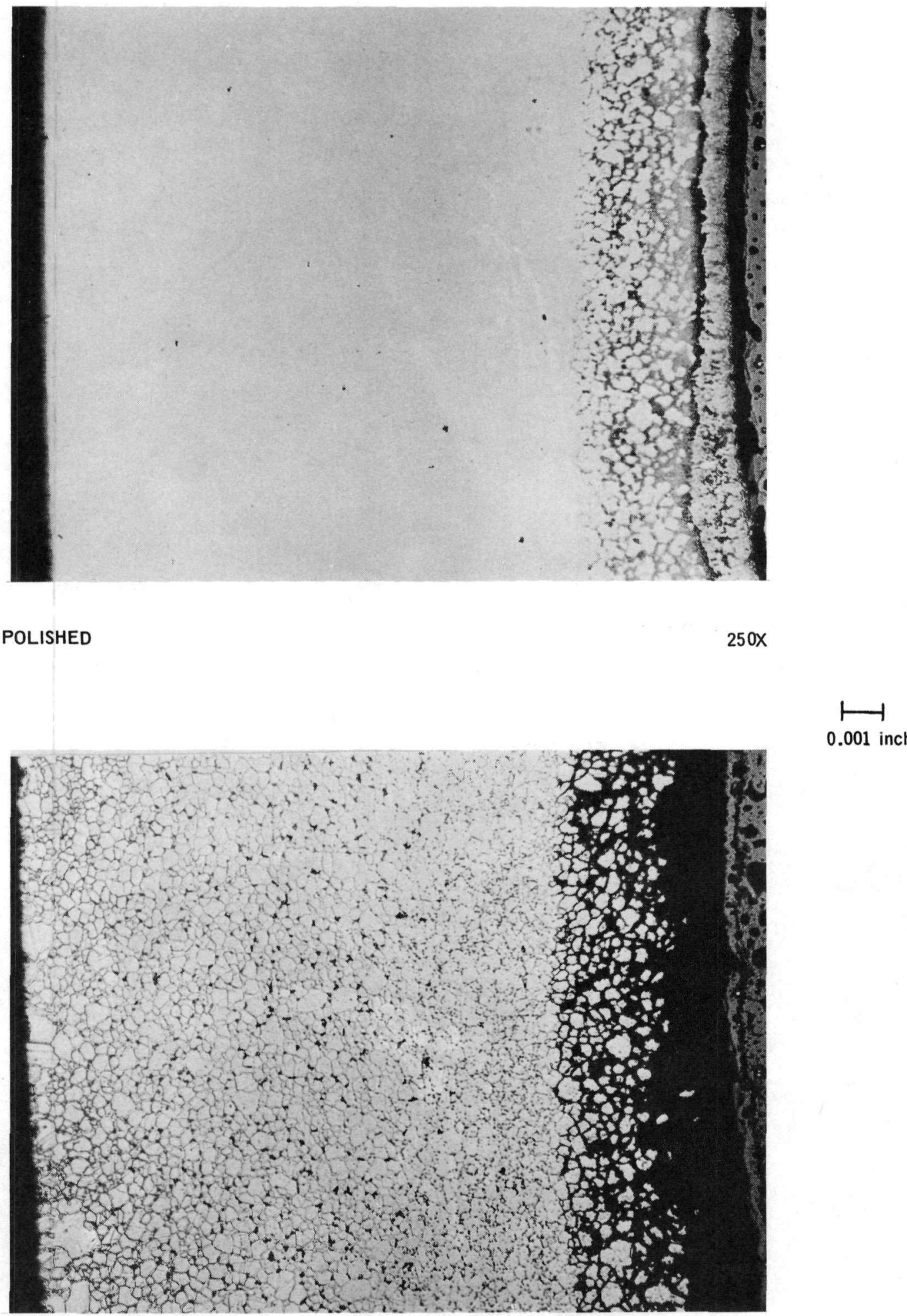

ETCHED 

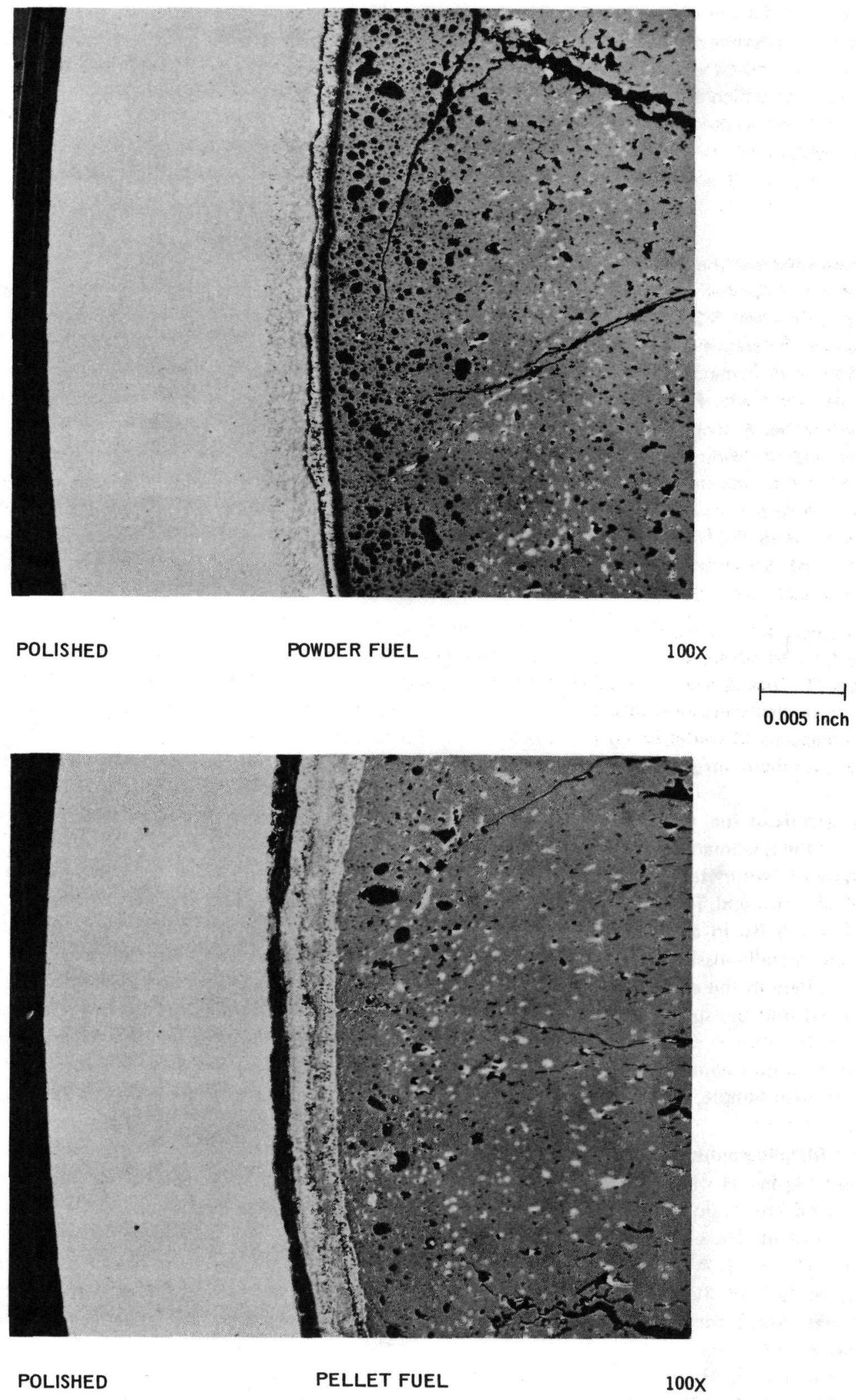

Figure 5-7 Comparison of Powder and Pellet Fuel-Cladding Reaction at Equivalent Cladding Temperatures 
The prominent feature of the pellet fuel specimen was the fuel-cladding reaction zone. This consisted of a uniform ring of metallic-appearing material, generally 0.003 to 0.004 inch thick but with local thickness of up to 0.006 inch. One specimen was etched with Vilellas reagent to detect sigma phase in the type 347 stainless steel cladding. Figure 5-8 shows micrographs which illustrate the effect of this etchant on the cladding and reaction zone. Figure 5.9 shows a higher magnification of the cladding etched for sigma phase.

Autoradiographs of the powder and pellet fuel specimens (Figures 5-3 and 5-6) may be found in Appendix C-7. Enhanced $\beta-\gamma$ activity and decreased $\alpha$ activity were noted adjacent to the cladding where very high fuel burnup occurred.

\subsubsection{Electron Microprobe Examination}

An electron microprobe examination was performed on the opposite face (Figure 5-10) of the pellet fuel section described in subsection 5.2.1. Details regarding the instrument and experimental procedure used in the examination may be found in Reference 5 .

A qualitative determination of the distribution of cladding elements and fission products in the fuel-cladding reaction zone was made. Figure $5-11$ is a $500 \mathrm{X}$ micrograph of the area examined showing the 0.004 to 0.005 inch thick reaction zone. A specimen current image display is also shown for orienting particular features in the K $\alpha \mathrm{x}$-ray pulse image displays shown in subsequent figures. Comparisons may be made by utilizing the grid shown on the displays. Key grid points are marked on the photographs. It is noted that the specimen current and $\mathrm{x}$-ray image displays are right to left mirror images of the micrograph and are $425 \mathrm{X}$ magnification. K $\alpha \mathrm{x}$-ray pulse images for the primary cladding constituents $\mathrm{Fe}, \mathrm{Ni}$, and $\mathrm{Cr}$ are shown in Figure 5-12. Stratification of these elements is evident. A quantitative determination of the relative $\mathrm{Fe}, \mathrm{Ni}$, and $\mathrm{Cr}$ concentrations was made at points across the reaction zone. The composition at each point going from the fuel side to the cladding side is shown in Figure 5-13.

Iron appeared to be the most mobile of the cladding constituents and was found combined with metallic fission products as far into the fuel as the equiaxed grain region. Free iron was found in the fuel matrix in proximity to the reaction zone. $\mathrm{Cr}$ was detected combined with fission products in the fuel near the fuel-cladding reaction zone. Pd, Mo, $\mathrm{Ba}$, and $\mathrm{Cs}$ were also detected in the fuel-cladding reaction zone. The highest concentra+: 5 of these fission products were found adjacent to the cladding base metal. Figures 5-14 and 5-15 qualitatively shurv the concentrations of these elements. A specimen current image is included because the location of the grid is slightly offset from that of Figure 5-11.

Small islands of fuel were found in the reaction zone. These appear as grey inclusions in the micrograph and as black spots on the specimen current image, Figure 5-11.

Analysis of two metallic agglomerations in the outer fuel region (outside of the columnar grains) indicated the presence of $\mathrm{Mo}, \mathrm{Ru}$, and $\mathrm{Tc}$ in the ratio of $1.0,0.4$, and 0.25 . Metallic fission products in the columnar grain region contained Mo and $R u$ in approximately equal quantities along with traces of Tc and Rh. Regions in the fuel matrix adjacent to the metallic fission products were analyzed. The only fission product detected was a trace of $\mathrm{Zr}$.

A grey phase in the equiaxed grain region of the fuel matrix was examined and $\mathrm{Zr}, \mathrm{Ba}, \mathrm{Cs}$, and $\mathrm{Sr}$ were found. It was determined that the spacial distribution of $\mathrm{Ba}$ and $\mathrm{Zr}$ were identical and coincided with the second phase region. The $\mathrm{Cs}$ rich areas were in proximity with, but not identical to, the Ba- $\mathrm{Zr}$ rich areas. The Sr was barely detectable and the exact distribution could not be determined. Although this grey phase had an appearance similar to the alumina found in a control sample, no Al was detected. It is plausible that the second phase is barium zirconate.

\subsubsection{Other Metallographic Specimens}

Sections $A$ and $H$ of the pellet fuel and sections $A$ and $B$ of the powder fuel are described in Appendix $C$. Micrographs and autoradiographs of these specimens are presented there as well as autoradiographs of the $E$ sections previously described. These results are summarized below.

Pellet fuel section A (Figure C-1) from the low power end of the pellet fuel had a calculated cladding inside surface temperature of $1220^{\circ} \mathrm{F}$ or $110^{\circ} \mathrm{F}$ lower than the $\mathrm{E}$ sections previously described (subsection 5.2 .2 ). It is significant that except for an isolated penetration of 0.002 inch, very little fuel-cladding reaction occurred at this cladding temperature.

Pellet fuel section $\mathrm{H}$, (Figure C-2) came from the high power end (top end) of the fuel and had a cladding inside surface temperature of $1400^{\circ} \mathrm{F}$. A cladding thickness reduction of 0.004 inch occurred. Molten fuel from this section was relocated into section $A$ above. 

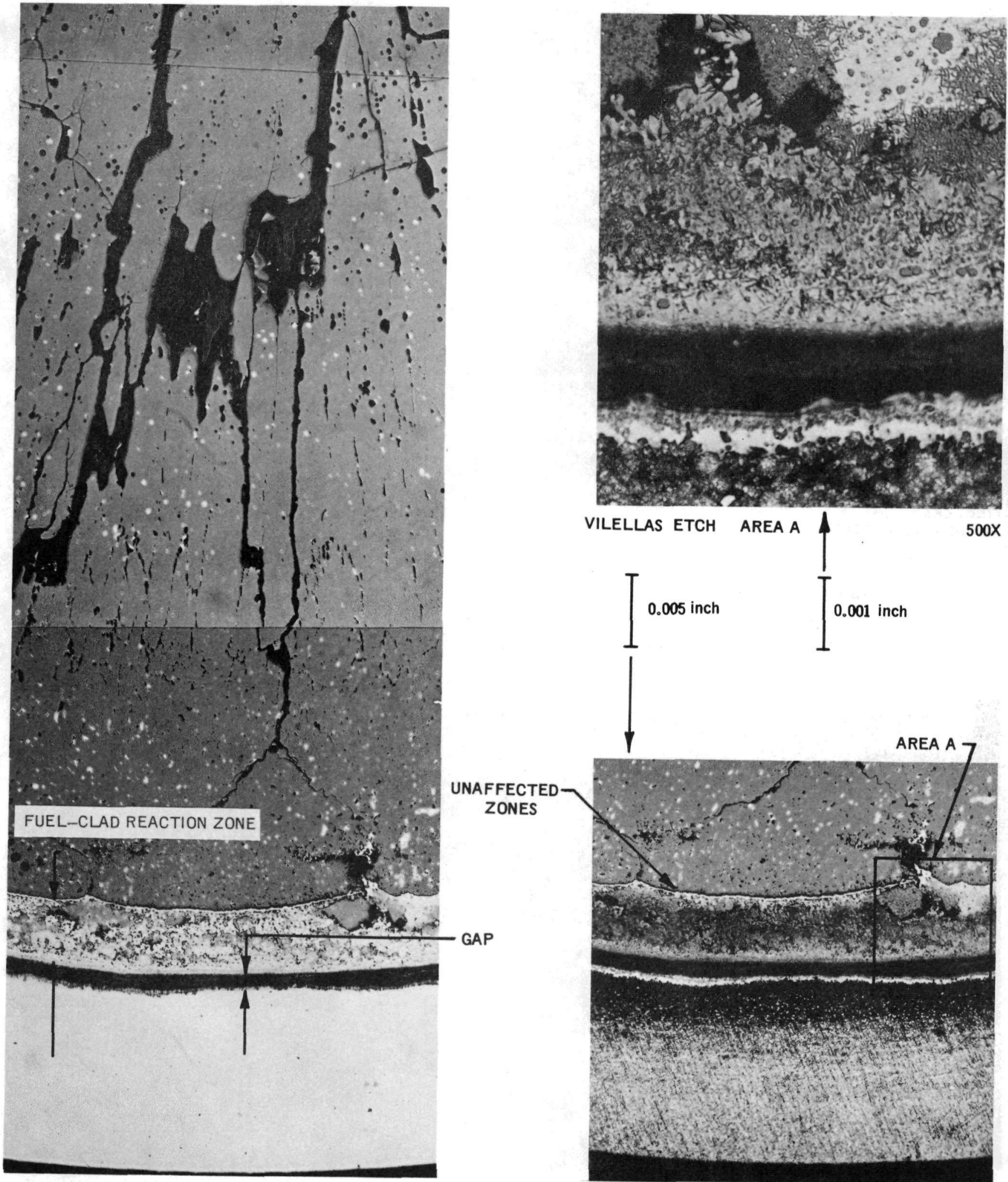

AS POLISHED TYPICAL RADIUS

$100 x$

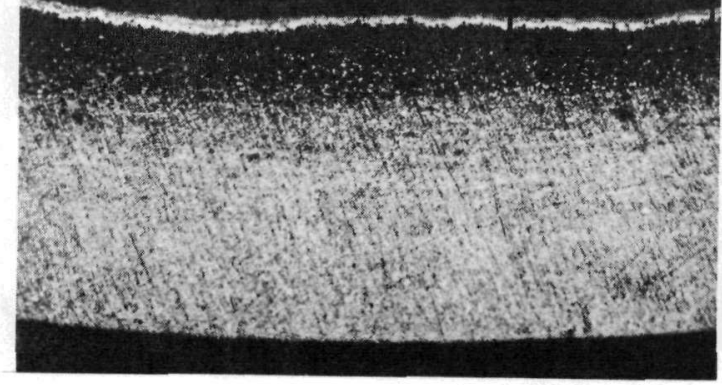

VILELLAS ETCH

$500 x$

Figure 5-8 Pellet Fuel Section E Micrographs 


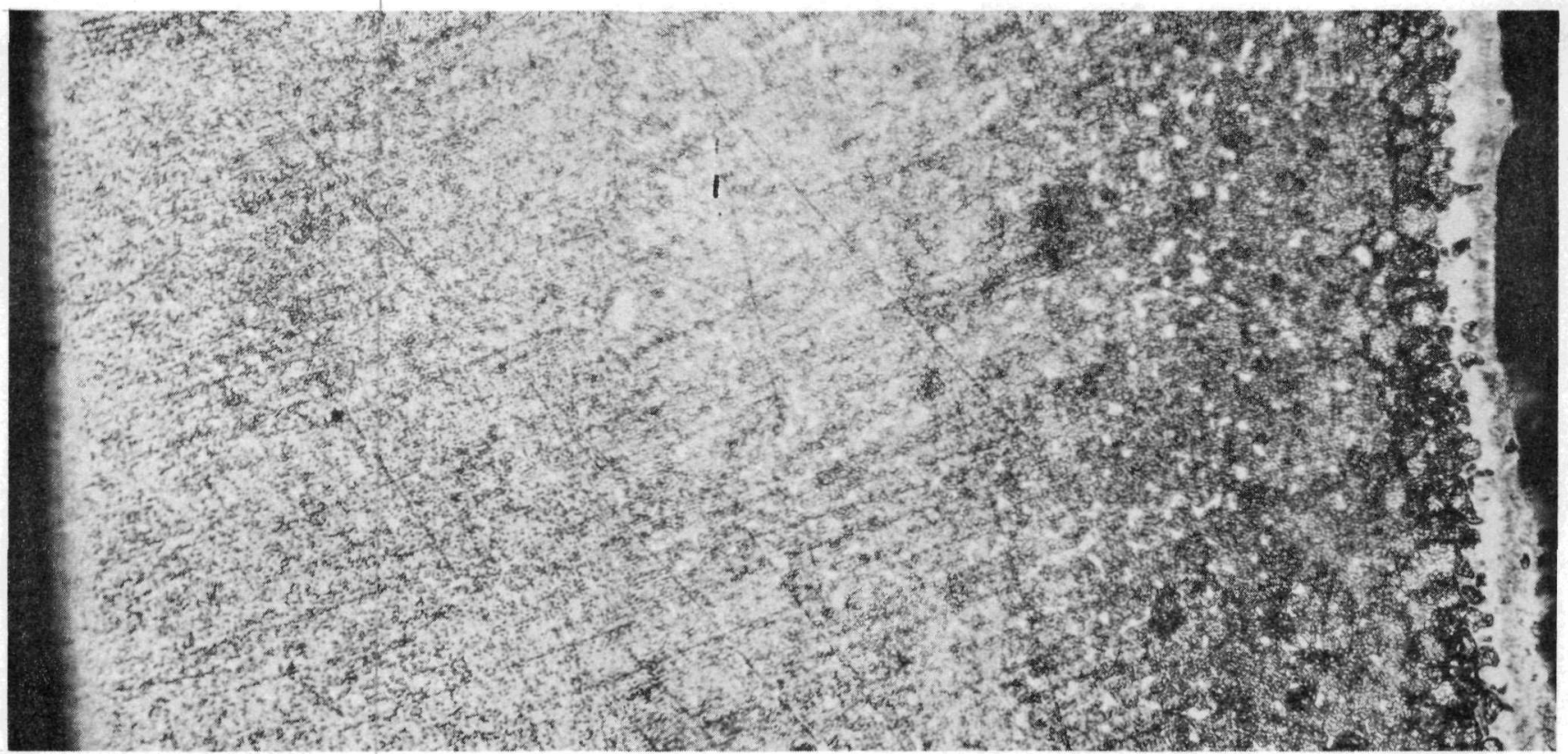

VILELLAS ETCH

TO SHOW SIGMA PHASE

CLADDING OUTSIDE SURFACE TEMPERATURE $=1200^{\circ} \mathrm{F}$

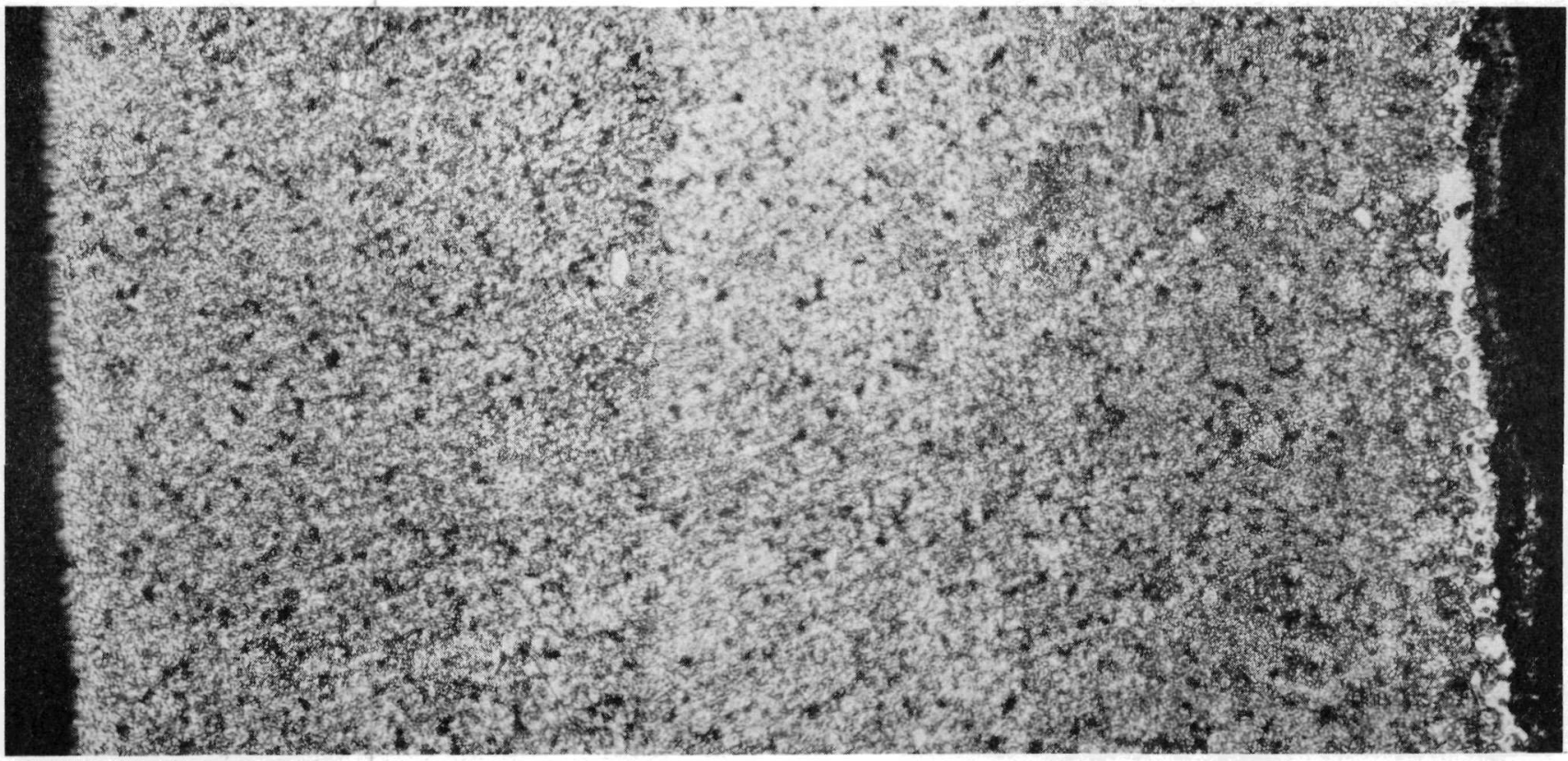

Figure 5-9 Sigma Phase in 347SS Fuel Cladding, Pellet Fuel Section E 


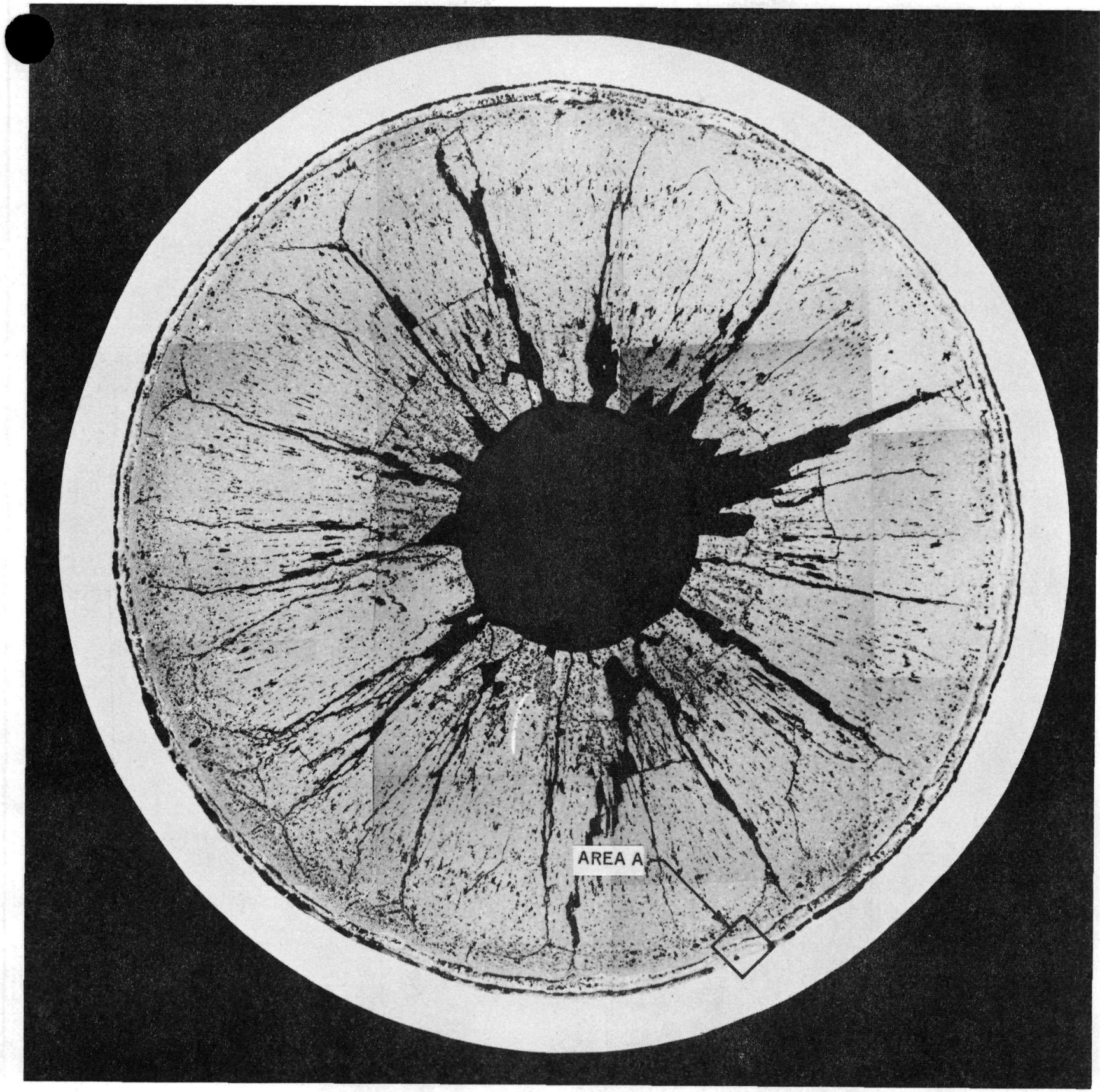

SECTION D

Figure 5-10 Electron Microprobe Specimen, Pellet Fuel Section D 


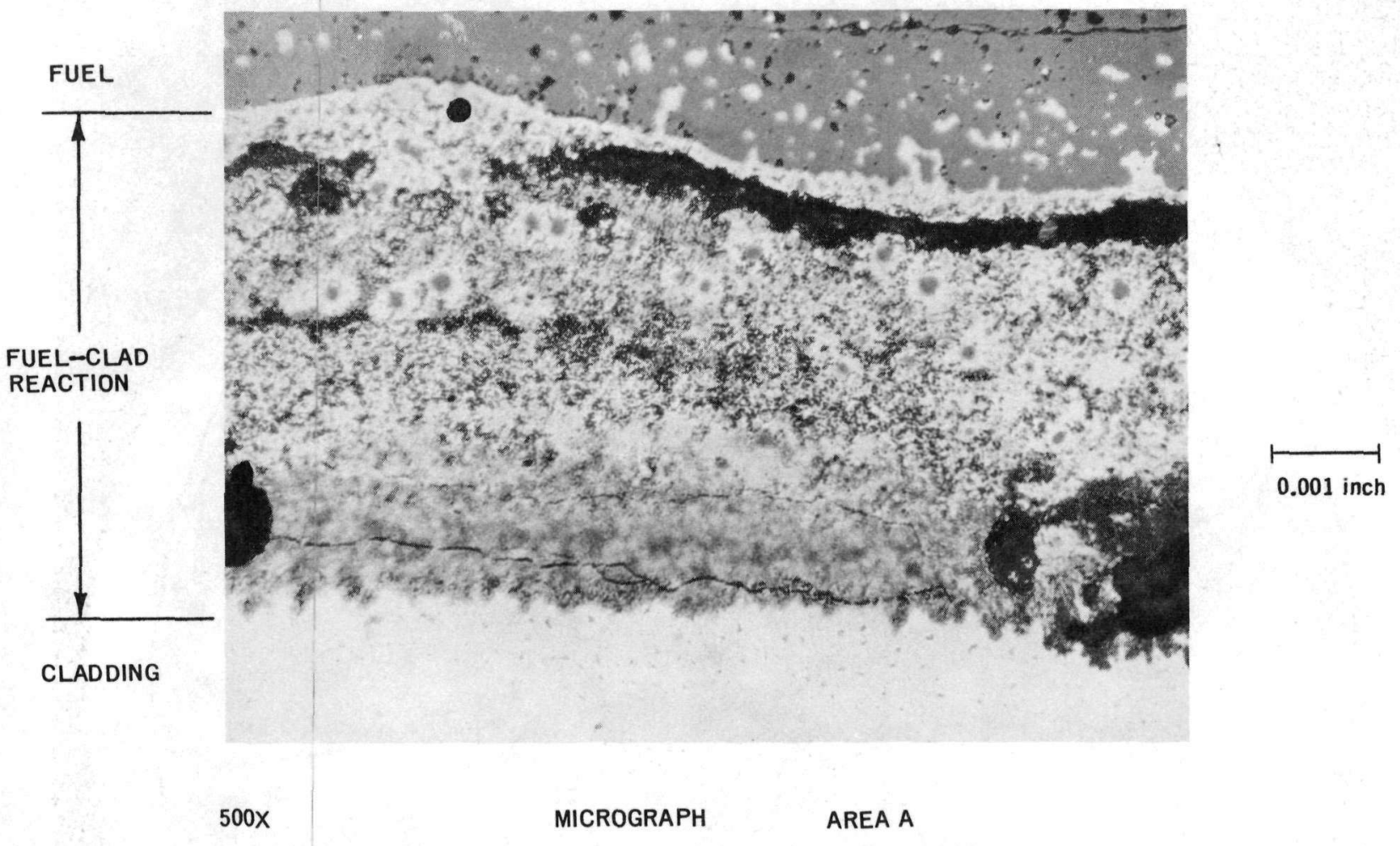

MIRROR IMAGE
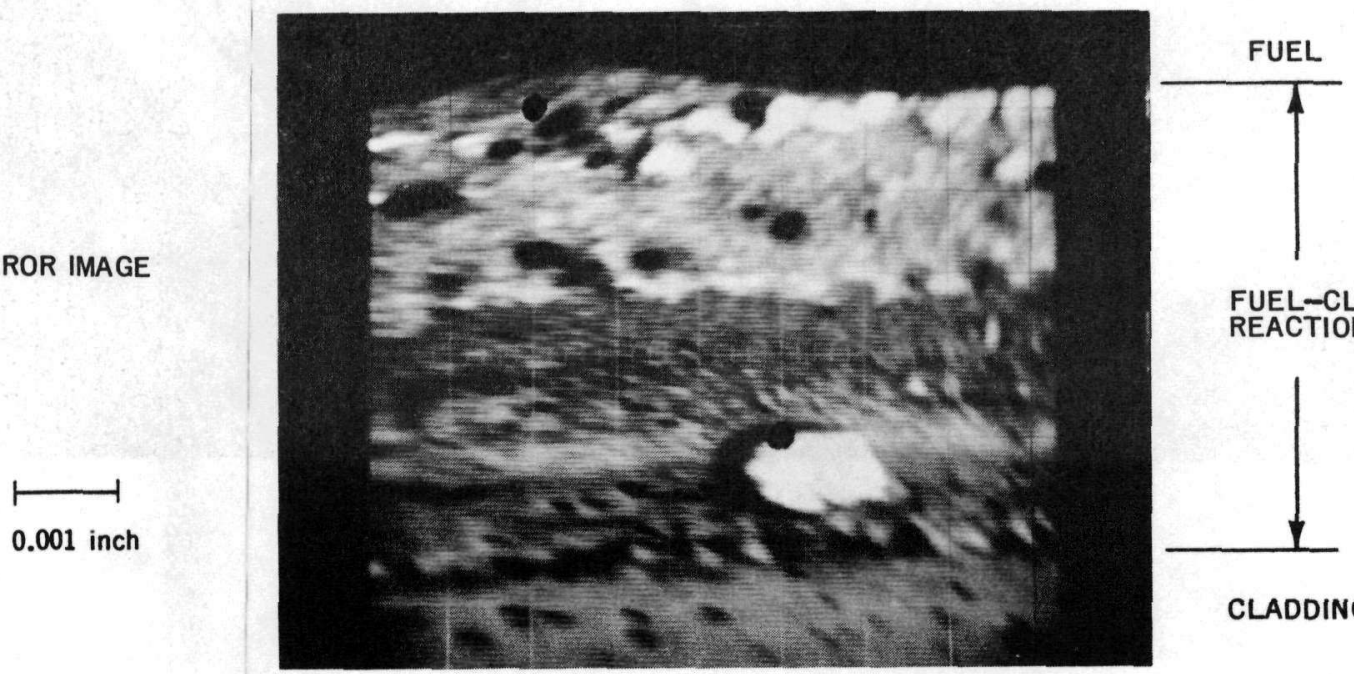

$425 x$

SPECIMEN CURRENT IMAGE

FUEL-CLAD

REACTION

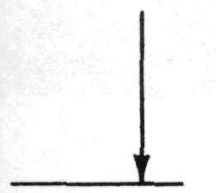

CLADDING

Figure 5-11 Area of Fuel-Cladding Reaction Zone Examined with Electron Microprobe 


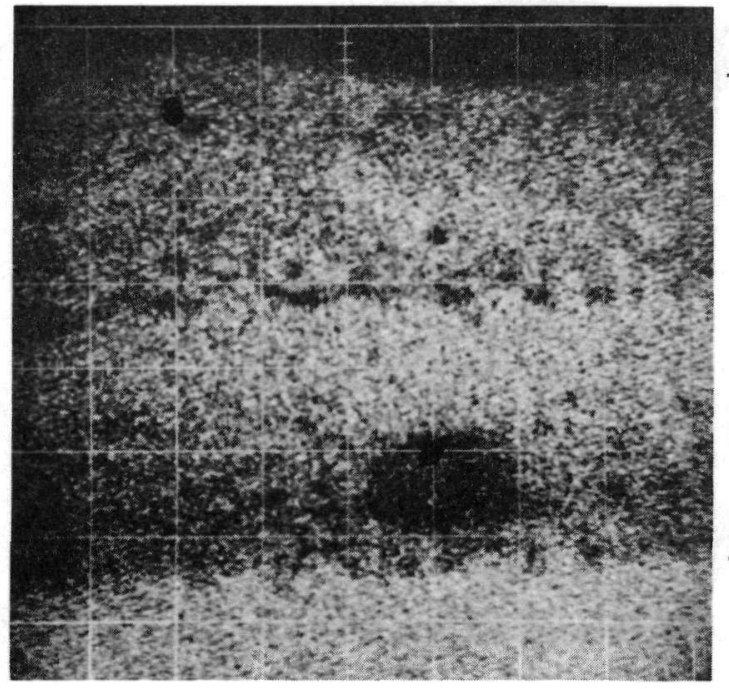

Fe $K \alpha X$ X-RAY PULSE IMAGE

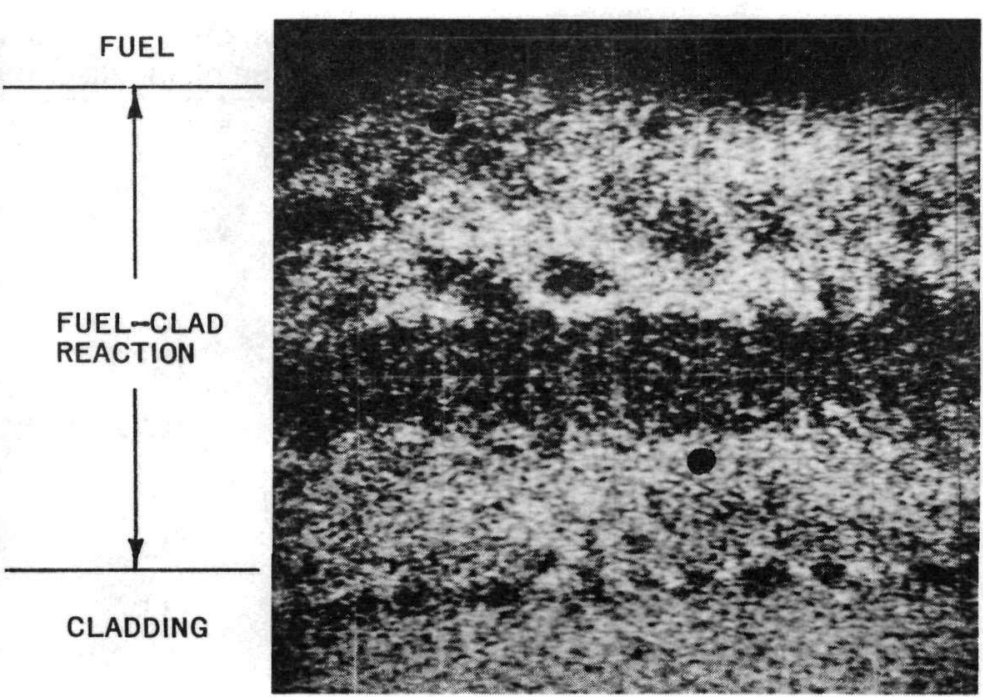

Cr $\mathrm{K} \alpha$ X-RAY PULSE IMAGE

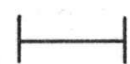

0.001 inch

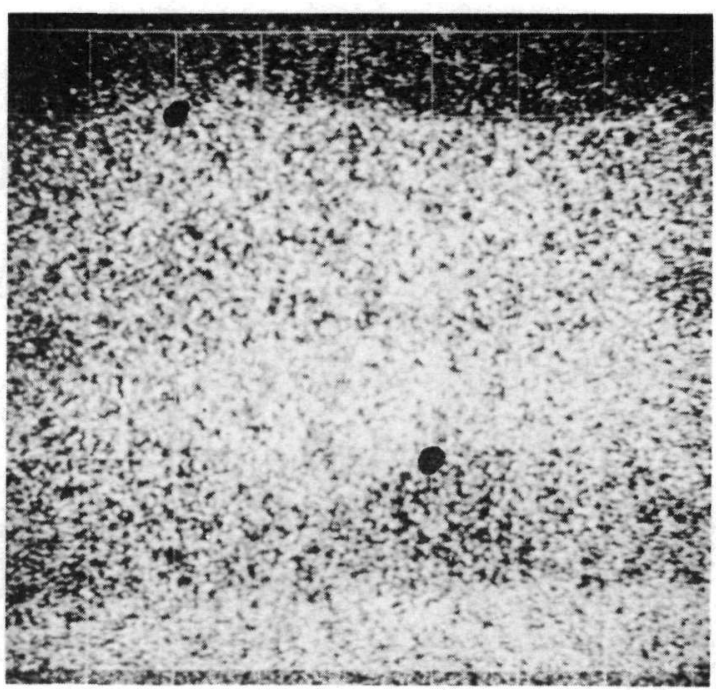

Ni $K \alpha \quad X-R A Y$ PULSE IMAGE
FUEL
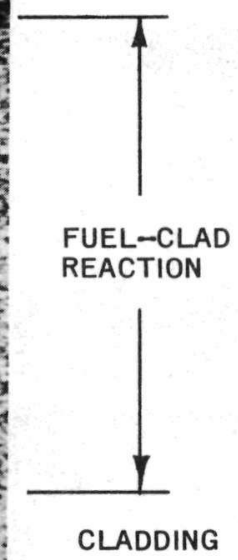

Figure 5-12 Locations of Fe, Ni and $\mathrm{Cr}$ in the Fuel-Cladding Reaction Zone 


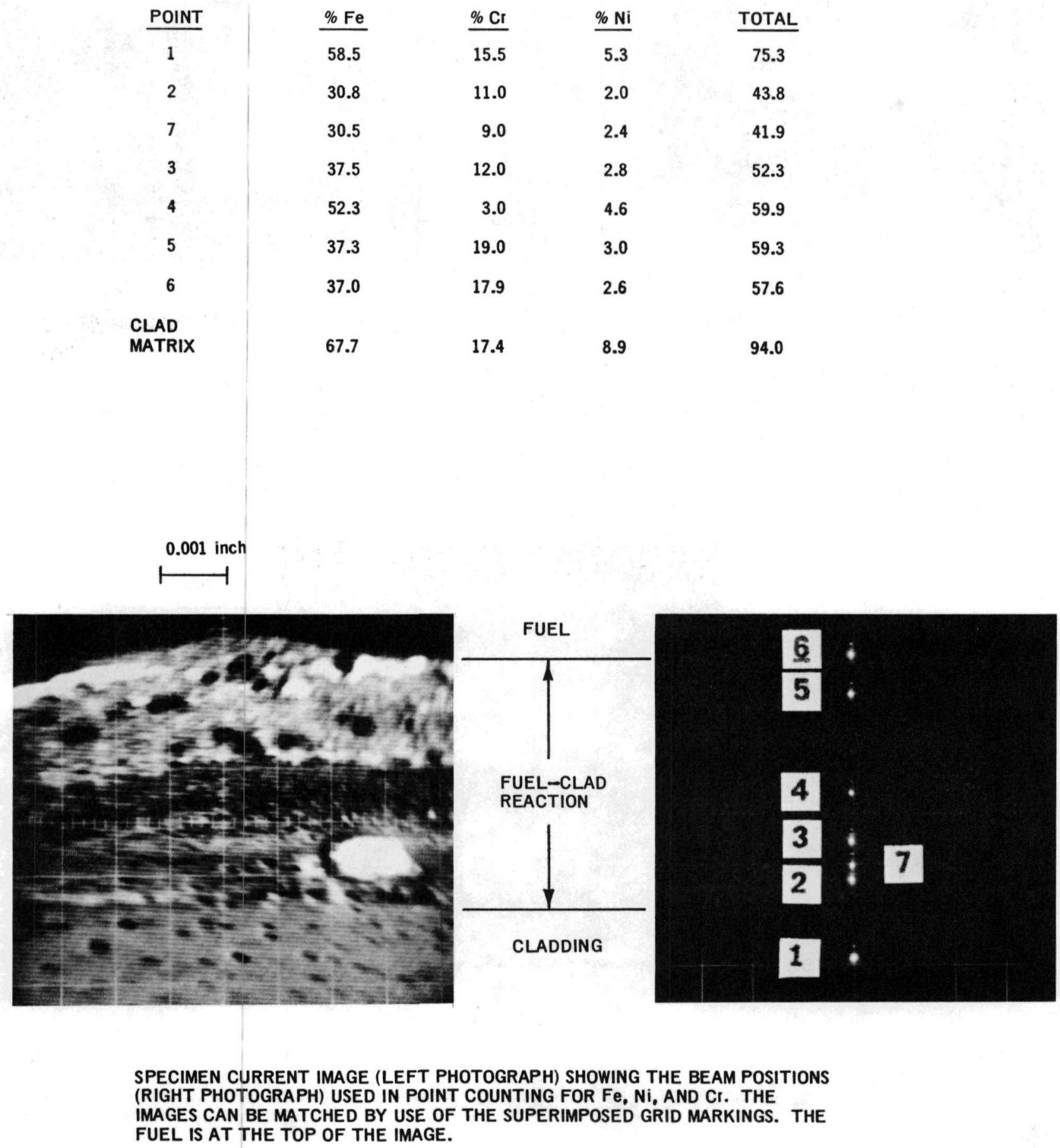

Figure 5-13 Fe, Ni, and $\mathrm{Cr}$ at Selected Points in the Fuel-Cladding Reaction Zone 


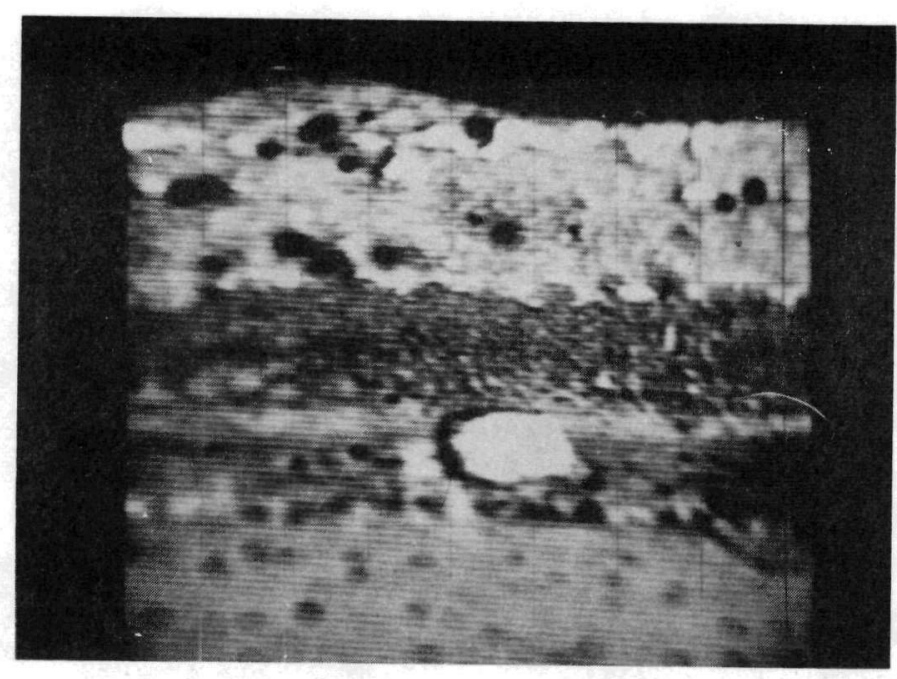

FUEL

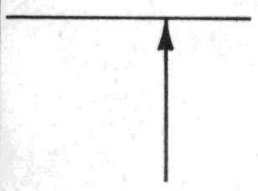

FUEL-CLAD

REACTION

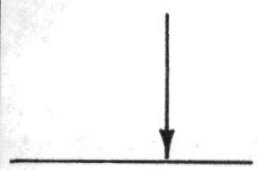

CLADDING

SLIGHTLY DIFFERENT POSITION

SPECIMEN CURRENT IMAGE

0.001 inch

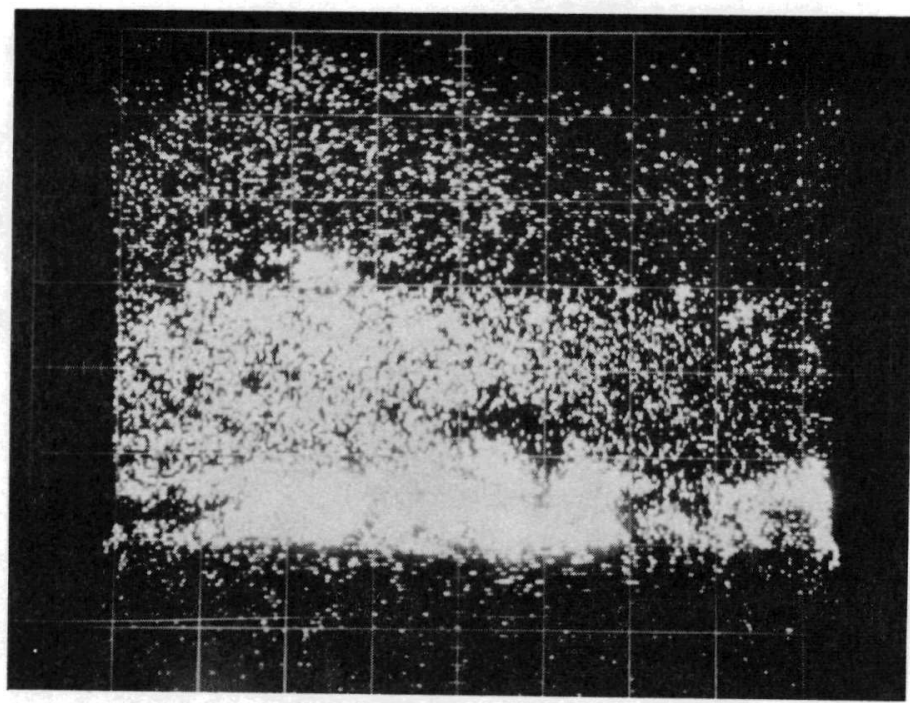

FUEL

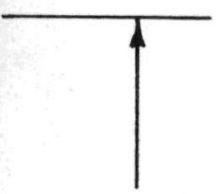

FUEL-CLAD

REACTION

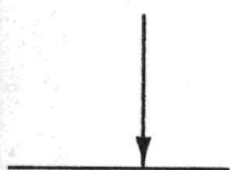

CLADDING

Pd L $\alpha$ RATE OUT X-RAY IMAGE

Figure 5-14 Distribution of Pd in the Fuel-Cladding Reaction Zone 


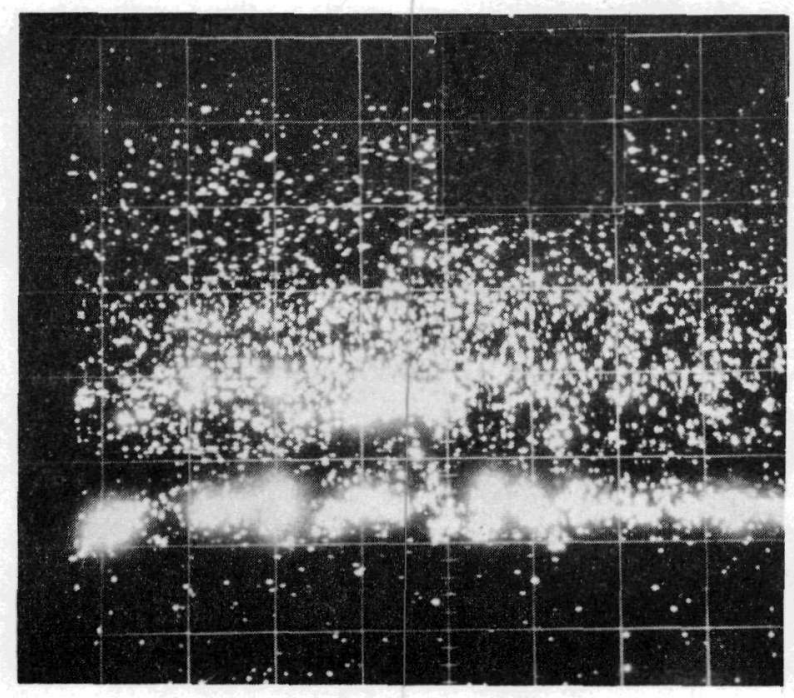

MO L $\alpha \quad X-R A Y$ RATE OUT IMAGE

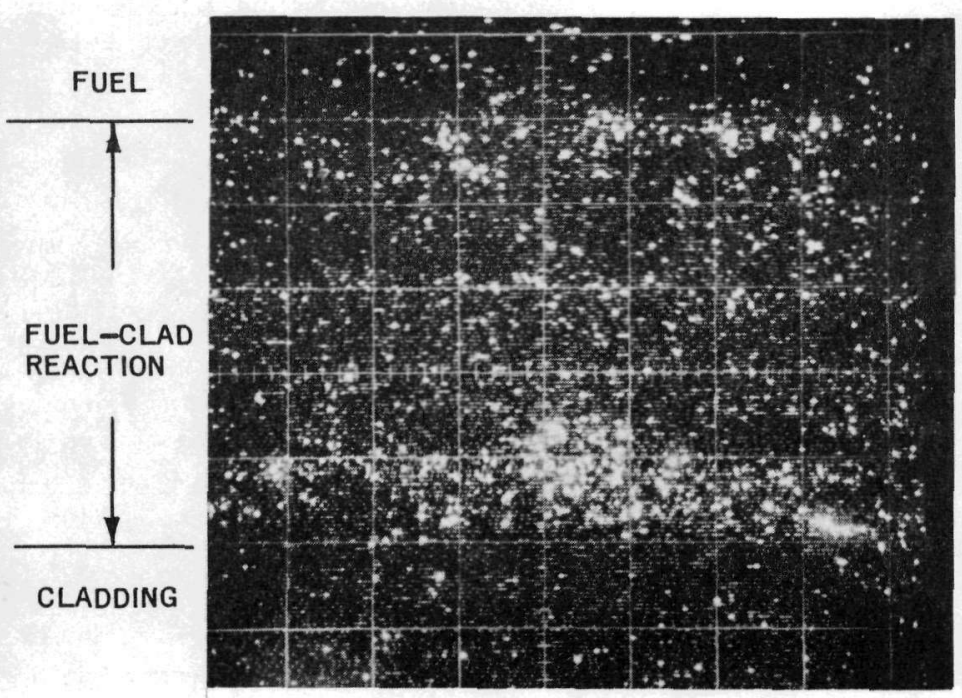

Cs L $\alpha \quad X$-RAY RATE OUT IMAGE

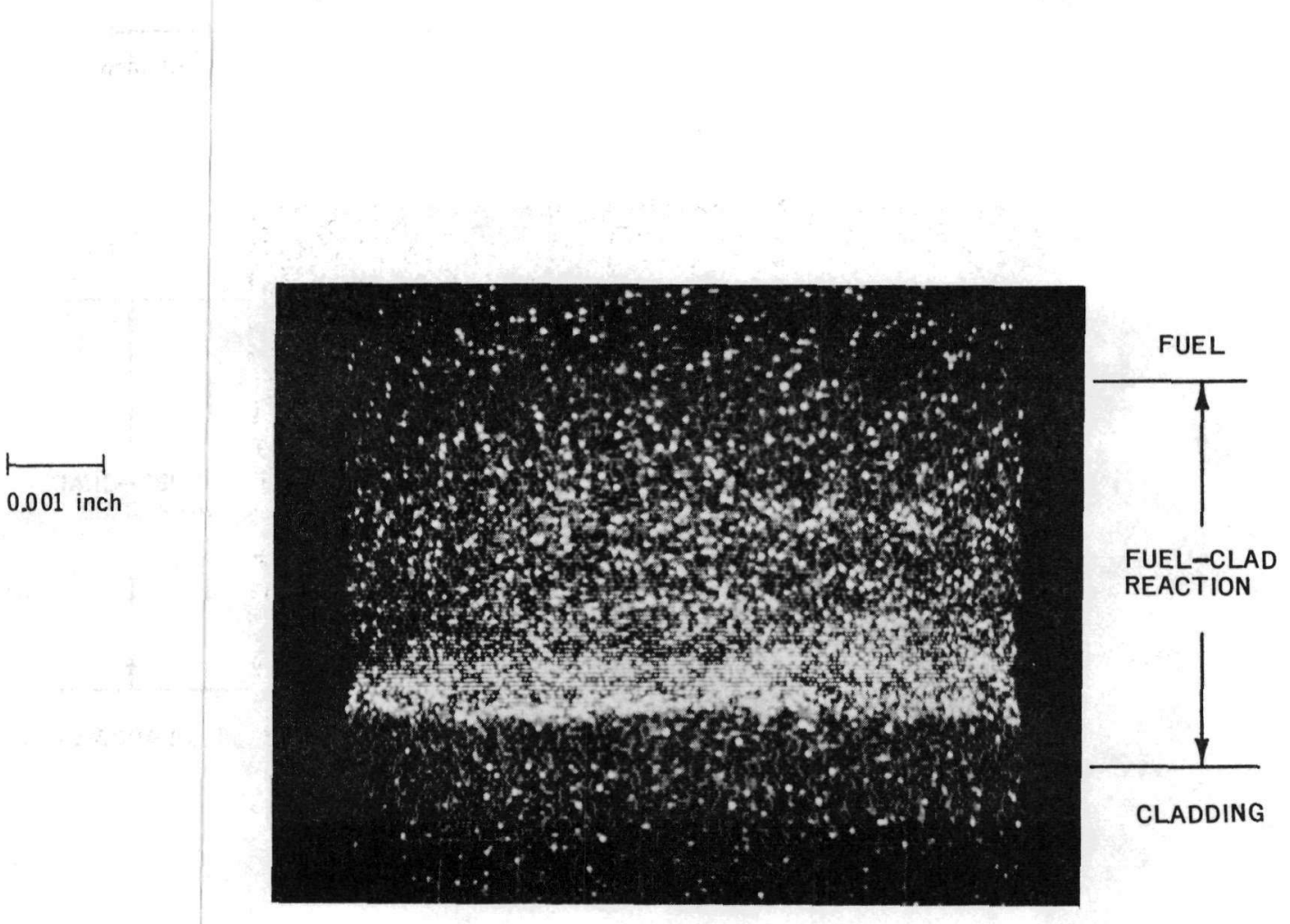

Ba L $\alpha$ X-RAY RATE OUT IMAGE

Figure 5-15 Distribution of Mo, Cs, and Ba in the Fuel-Cladding Reaction Zone 
Powder fuel section B (Figures C-3 and C-4) came from the high-power (bottom) end of the powder fuel and exhibited a classical molten structure which was used to make $\int k d t$ to melt calculations. The power and temperatures were the same as pellet fuel section $\mathrm{H}$ (above) and again significant fuel-cladding reaction occurred.

Powder fuel specimen $A$ (Figure $C-5$ ) is a longitudinal section the top of which was adjacent to powder fuel section B, above. Although extensive fuel-cladding reaction occurred at the upper end of this specimen where the cladding inside surface temperature was about $1400^{\circ} \mathrm{F}$, a sharp reduction in cladding attack occurred as axial heat transfer apparently reduced the cladding temperature toward the bottom of the pin. The sharp reduction in cladding attack suggests that a threshold temperature for this reaction exists. It was not possible to determine the temperature at which this occurred from this specimen. However, little reaction occurred at a cladding inside surface temperature of $1220^{\circ} \mathrm{F}$ in pellet fuel specimen $\mathrm{A}$, while reaction occurred in all areas where cladding inside surface temperatures were in excess of $1300^{\circ} \mathrm{F}$. It is probable therefore, that a temperature near $1300^{\circ} \mathrm{F}$ is required for the reaction to proceed at a significant rate.

Both alpha and $\beta-\gamma$ autoradiographs of the fuel sections are shown in Figures $\mathrm{C}-6$ through $\mathrm{C}-9$. A brief discussion is included in Appendix C-6.

\section{DISCUSSION OF RESULTS}

Microstructural similarities and $\int k d t$ calculations lead to the conclusion that the pellet and powder fuels exhibited similar thermal performance. Sections from the pellet and powder fuel which were irradiated at the same power had similar columnar radii. These were $82 \%$ of the fuel radius in the pellet fuel and $80 \%$ of the radius in the powder fuel. Central voids of $32 \%$ existed in both fuels. In the molten fuel sections the powder fuel showed a molten radius of $46 \%$. A central void of $54 \%$ existed in the comparable pellet specimen where molten fuel had slumped downward. The columnar grain radii in these two sections were similar, $81 \%$ for the pellets and $79 \%$ for the powder.

The powder fuel specimen with its well defined molten and columnar grain radii provided data for quantitative calculation of the thermal characteristics for high burnup mixed oxide fuel. The calculational technique of Robertson ${ }^{6}$ was used to calculate surface-to-melting,

$$
\int_{T_{s}}^{T_{m}} k d t
$$

and surface-to-columnar grain,

$$
\int_{T_{S}}^{T_{c g}} k d t
$$

integrated thermal conductivities. The values calculated for each integral were:

$$
\begin{aligned}
& \int_{T_{s}}^{T_{m}} k d t=33 \text { watts } / c m \\
& \int_{T_{s}}^{T_{c g}} k d t=19.6 \text { watts } / \mathrm{cm}
\end{aligned}
$$

Where:

$$
\begin{aligned}
& T_{m}=\text { melting temperatures } \\
& T_{c g}=\text { temperature of columnar grain growth } \\
& T_{s}=\text { fuel surface temperature }
\end{aligned}
$$


TABLE 6-1

\section{THERMAL IRRADIATION PROPERTIES FOR PELLET AND POWDER FUEL CAPSULE E5B}

\begin{tabular}{|c|c|c|c|c|c|c|}
\hline & Linear Power & $\begin{array}{l}\text { Inside Surface } \\
\text { Temperature, }\end{array}$ & $\begin{array}{c}\text { Cladding } \\
\text { Fuel Surface } \\
\text { Temperature, Ts }\end{array}$ & $\begin{array}{c}\text { Thermal } \\
\text { Conductance } \\
\text { Btu }\end{array}$ & $\int_{T_{3}}^{T_{c}} k d t$ & $\begin{array}{c}\text { Fuel Center } \\
\text { Temperature, } \\
T_{\mathbf{C}}\left({ }^{\circ} \mathrm{Cl}\right.\end{array}$ \\
\hline $\begin{array}{l}\text { Fuel Section } \\
\text { B Pellet }\end{array}$ & $\begin{array}{c}(\mathbf{k W} / \mathrm{ft}) \\
20.4\end{array}$ & $\begin{array}{l}\left({ }^{\circ} \mathrm{F}\right) \\
1220\end{array}$ & $\begin{array}{r}{ }^{\circ} \mathrm{Cl} \\
1360\end{array}$ & $\begin{array}{c}\left(h-\mathrm{ft}^{2}{ }^{\circ} \mathrm{F}\right) \\
960\end{array}$ & $(W / \mathrm{cm})$ & 2640 \\
\hline E Pellet & 22.5 & 1330 & 1230 & 1470 & 30.0 & 2580 \\
\hline F Pellet & 22.9 & 1360 & 1350 & 1235 & 28.1 & 2610 \\
\hline G Pellet & 23.5 & 1390 & 1280 & 1535 & 25.2 & 2420 \\
\hline B Powder & 23.5 & 1390 & 1250 & 1630 & 33.0 & 2750 (Molten) \\
\hline E Powder & 22.5 & 1330 & 1230 & 1470 & 30.0 & 2580 \\
\hline
\end{tabular}

A fuel melting temperature of $2750^{\circ} \mathrm{C}$ * was assumed to calculate a columnar grain growth temperature of $2150^{\circ} \mathrm{C}$ and a fuel surface temperature of $1250^{\circ} \mathrm{C}$. Utilizing these values a fuel-to-cladding gap conductance of $1630 \mathrm{Btu} / \mathrm{h} \cdot \mathrm{ft}^{2}{ }^{\circ} \mathrm{F}$ was calculated using the $\int k d t$ curve of Craig and Baily. ${ }^{8}$ The calculated columnar grain growth temperature of $2150^{\circ} \mathrm{C}$ agrees closely with values reported by Hausner and Nelson and by Potter and Elyard ${ }^{10}$ for $\mathrm{UO}_{2}$. The resulting value of $1630 \mathrm{Btu} / \mathrm{h}-\mathrm{ft}^{2}{ }^{\circ} \mathrm{F}$ for gap conductance is consistent with the results of Craig et al. ${ }^{11}$

Because no molten radius existed in all powder or pellet fuel samples, calculations were based on the columnar grain growth radius assuming a temperature of $2150^{\circ} \mathrm{C}$ for columnar grains to initiate. The results of these calculations are tabulated in Table 6-1.

With the exception of one low value the gap conductances calculated for this experiment range from 1235 to 1630 for linear powers of 22.5 to $23.5 \mathrm{~kW} / \mathrm{ft}$. Four of these five values fall in the narrow range of 1470 to 1630 $B t u / h-\mathrm{ft}^{2}{ }^{\circ} \mathrm{F}$. These values of gap conductance include any effect which results from the presence of the fuel-cladding reaction zone. The results from these experiments indicate that the effective gap conductance between the fuet and cladding including the reaction zone is comparable to pins where no reaction zone is present.

The high fission gas release fractions observed in this experiment are comparable to other gas release data from high burnup mixed oxide fuels irradiated with fuel center temperatures in the range of $2300^{\circ}$ to $2600^{\circ} \mathrm{C}$. Typical gas release results from other thermal flux experiments are noted in Table 6-2.

Fuel volume measurements ${ }^{t}$ after irradiation showed that the fuel volume decreased by $3 \%$ to $4 \%$ during irradiation. Post-irradiation microstructures confirmed that gross densification of the fuel occurred during the irradiation, resulting in a lower fuel volume after the test. These results indicate that the $84 \%$ smeared density fuel used in these experiments was sufficiently low to result in minimal mechanical fuel-cladding interaction. Fuel swelling rates calculated from these pins indicate a rate of $7 \%$ per $100,000 \mathrm{MWd} / \mathrm{Te}$ or $0.28 \% \Delta \mathrm{V} / \mathrm{V}$ per $10^{20} \mathrm{f} / \mathrm{cc}$, assuming a post-irradiation fuel density of $97 \%$ theoretical.

Cladding inside surface temperatures in the $1330^{\circ} \cdot 1400^{\circ} \mathrm{F}$ range resulted in general fuel-cladding reaction (or fission product-cladding reaction) to a depth 0.003 to 0.004 inch with both powder and pellet fuel. $A$ summary of the depth of cladding reaction is shown in Table 6.3. Although the deepest isolated penetration ( 0.0051 inch) was found on a pellet fuel specimen, the general appearance of comparable sections indicates equivalent depths of generalized attack in powder and pellet fuel cladding. Temperature dependence of the cladding reaction was confirmed by the finding of only localized reaction to a depth of 0.002 inch in a specimen with cladding inside surface temperature of $1220^{\circ} \mathrm{F}$.

- Out-of-pile melting point experiments by Krankote and Craig ${ }^{7}$ indicate that the melting point of mixed-oxide fuel is depressed by $50^{\circ}$ to $100^{\circ} \mathrm{C}$ at burnups in excess of $100,000 \mathrm{MWd} / \mathrm{Te}$.

$t$ The volume determinations were made from fuel-blanket interface micrographs and cross-section cuts through the fuel pin and included axial fuel growth and center void volumes. ${ }^{12}$ 
Out-of-pile compatibility experiments by T. Lauritzen at $1400^{\circ} \mathrm{F}$ for 1000 hours resulted in no fuel-cladding reaction for stoichiometric and hypostoichiometric fuel. ${ }^{18}$ Only slight attack from hyperstoichiometric fuel was found in these 1000 -hour tests. It is probable, therefore, that the presence of fission products contributed to the substantial reaction observed in the present work. The mechanism may be through grain boundary attack since whole grains were observed adjacent to, but disconnected from, the cladding base metal.

Mechanisms associated with this cladding reaction suggest that oxygen may play a role in these reactions. For example, oxygen is liberated when the metals in mixed-oxide fuels are consumed by fission. Much of this oxygen will combine with the fission fragments, depending upon which species is fissioned, the flux spectrum, the temperature and stoichiometry of the fuel. Some of the liberated oxygen will be available to raise the $\mathrm{O} / \mathrm{M}$ ratio. ${ }^{19}$ Thermodynamic analysis indicates that when the $O / M$ ratio reaches 2.0 , (or perhaps even a slightly lower value) the chromium in stainless steel should begin to oxidize. Thus, the fuel should become more aggressive as burnup proceeds and the oxygen potential in the fuel increases. It is well known, however, that stainless steel forms a protective film which effectively prevents oxidation in many environments where extensive reaction would be thermodynamically predicted. This is supported by the results of out-of-pile tests where very little reaction is observed, even with hyperstoichiometric fuels.

Low melting temperature fission-product metals may also play a part by liquid metal attack. Antimony, for example, is particularly aggressive in this respect. Tellurium, for which antimony is a precurser, has often been found in the fuel-cladding gap.

As additional information is obtained from high cladding temperature tests and related out-of-pile experiments, it is reasonable to expect that a clear understanding of the mechanisms associated with cladding-fuel reactions will be developed. Results from these efforts should provide the necessary information for the commitment of near term LMFBR's. Advanced LMFBR's that will be operated at higher power levels and temperatures will require continuing development work to establish means for minimizing or eliminating these reactions.

TABLE 6-2

FISSION GAS RELEASE DATA FROM THERMAL FLUX IRRADIATIONS

\begin{tabular}{|c|c|c|c|c|c|}
\hline Fuel Pin & $\begin{array}{l}\text { O/M } \\
\text { Ratio }\end{array}$ & $\begin{array}{l}\text { Smeared } \\
\text { Density }\end{array}$ & $\mathrm{kW} / \mathrm{ft}$ & $\begin{array}{l}\text { Burnup } \\
\text { MWd/Te }\end{array}$ & $\begin{array}{c}\text { \% Fission Gas } \\
\text { Release }\end{array}$ \\
\hline$E 1 E^{\left({ }^{3}\right)}$ & 2.00 & 91 & 20 & 87,000 & 84 \\
\hline$E 1 F^{(13)}$ & 2.00 & 92 & $17 / 31$ & 75,000 & 96 \\
\hline$E 2 C-1^{(14)}$ & 2.00 & 82 & 20 & 117,000 & 89 \\
\hline $\mathrm{E} 2 \mathrm{C}-2^{(14)}$ & 2.00 & 91 & 20 & 108,000 & 97 \\
\hline E2D-1 $\left(\begin{array}{ll}15 & 5\end{array}\right.$ & 2.00 & 87.5 & 16 & 136,000 & 80 \\
\hline$E 2 D-2^{(15)}$ & 1.96 & 88.3 & 16 & 133,000 & 81 \\
\hline$E 2 F^{(16)}$ & 2.00 & 95.4 & - & 242,000 & 83 \\
\hline$E 2 G^{(16)}$ & 2.00 & 96.5 & - & 208,000 & 82 \\
\hline $\mathrm{E} 2 \mathrm{H}^{(16)}$ & 2.00 & 93.5 & . & 322,000 & 87 \\
\hline $\mathrm{E} 2 \mathrm{~J}-1\left({ }^{1} 7\right)$ & 1.98 & 89 & 20 & 124,000 & 73 \\
\hline E2J-2 ${ }^{(17)}$ & 1.98 & 89 & 20 & 125,000 & 79 \\
\hline E5B-1 & 2.00 & 84 & 23 & 148,000 & 91 \\
\hline E5B-2 & 2.00 & 84 & 23 & 148,000 & 78 \\
\hline
\end{tabular}


TABLE 6-3

\section{FUEL CLADDING REACTION MEASUREMENTS}

\begin{tabular}{|c|c|c|c|c|c|}
\hline $\begin{array}{l}\text { Specimen } \\
\text { Number }\end{array}$ & $\begin{array}{l}\text { Cladding Wall } \\
\text { Thickness (in.) }\end{array}$ & $\begin{array}{l}\text { Reduction in } \\
\text { Cladding Wall } \\
\text { Thickness (in.) }\end{array}$ & $\begin{array}{l}\text { Cladding Wall } \\
\text { Plus Reaction } \\
\text { Layer (in.) }\end{array}$ & $\begin{array}{l}\text { Reaction Layer } \\
\text { Thickness (in.) }\end{array}$ & $\begin{array}{l}\text { Calculated Cladding } \\
\text { Inside Surface } \\
\text { Temperature }\left({ }^{\circ} \mathrm{F}\right)\end{array}$ \\
\hline \multirow[t]{3}{*}{ Control } & $0.0153 b$ & 0 & -. & 0 & -- \\
\hline & $0.0152^{b}$ & 0 & .- & 0 & -. \\
\hline & $0.0151 b$ & 0 & -- & 0 & -- \\
\hline \multicolumn{6}{|l|}{ Powder } \\
\hline$A$ & 0.0120 & 0.0032 & 0.0170 & 0.00050 & 1400 \\
\hline \multirow[t]{4}{*}{$\mathbf{E}$} & 0.0118 & 0.0034 & 0.0161 & 0.0043 & 1330 \\
\hline & 0.0128 & 0.0024 & 0.0161 & 0.0038 & \\
\hline & 0.0136 & 0.0016 & 0.0166 & 0.0030 & \\
\hline & 0.0140 & 0.0012 & 0.0165 & 0.0025 & \\
\hline \multicolumn{6}{|l|}{ Pellet } \\
\hline \multirow[t]{2}{*}{ B } & 0.0132 & 0.002 & 0.0157 & 0.0025 & 1220 \\
\hline & 0.0152 & 0 & -. & 0 & \\
\hline \multirow[t]{4}{*}{$E$} & 0.0112 & 0.0040 & 0.0196 & 0.0084 & 1330 \\
\hline & 0.0129 & 0.0023 & 0.0178 & 0.0049 & \\
\hline & 0.0136 & 0.0016 & 0.0176 & 0.0040 & \\
\hline & 0.0136 & 0.0016 & 0.0184 & 0.0048 & \\
\hline \multirow[t]{6}{*}{$F$} & 0.0101 & 0.0051 & 0.0164 & 0.0063 & 1360 \\
\hline & 0.0111 & 0.0050 & 0.0164 & 0.0053 & \\
\hline & 0.0120 & 0.0032 & 0.0178 & 0.0058 & \\
\hline & 0.0121 & 0.0033 & 0.0168 & 0.0047 & \\
\hline & 0.0125 & 0.0027 & 0.0169 & 0.0044 & \\
\hline & 0.0136 & 0.0016 & 0.0172 & 0.0036 & \\
\hline \multirow[t]{3}{*}{$\mathbf{G}$} & 0.0116 & 0.0036 & 0.0178 & 0.0062 & 1390 \\
\hline & 0.0125 & 0.0027 & 0.0169 & 0.0044 & \\
\hline & 0.0139 & 0.0013 & 0.0164 & 0.0025 & \\
\hline
\end{tabular}

b Control measurements on unaffected cladding agree with pre-irradiation measurements.

\section{CONCLUSIONS}

The results of this experiment provided the first correlation of fuel-cladding reaction with temperature under this program. More specifically, it was observed that type 347 stainless steel cladding operating at temperatures in excess of $1300^{\circ} \mathrm{F}$ reacted with irradiated mixed-oxide fuel to a uniform depth of 3 to 4 mils of the cladding wall thickness in both pellet and powder pins. Localized cladding reaction of up to 5 mils was observed in the pellet pin.

A comparison of these observations on cladding reaction with other mixed-oxide fuel tests is difficult because of the high cladding temperatures that these pins experienced. The amount of reaction observed in the low temperature regions of these pins $\left(\sim 1220^{\circ} \mathrm{F}\right.$ cladding temperature) is 2 mils. This value is consistent with other observations on types 316,304 , and $1-800$ where the spread in reaction depth ranged from 0.5 mil to 3 mils. ${ }^{20}$ No comparable data are available from other experiments to relate to the high temperature results. 
Fuel volume changes during irradiation indicated that both the powder and pellet fuel at comparable smeared densities exhibited a growth rate of approximately $0.28 \% \Delta \mathrm{V} N$ per $10^{20} \mathrm{f} / \mathrm{cc}$ assuming a post-irradiation fuel density of $97 \%$ theoretical. Fuel pin diameter changes that occurred during irradiation were $1.2 \%$ and $0.7 \%$ for the pellet and powder pin, respectively. The thermal performances of the two fuel types, as evidenced by the post-irradiation microstructure, indicated comparable end-of-life thermal conductivity and gap conductance. Gap conductance values of 1470 to $1630 \mathrm{Btu} / \mathrm{h}-\mathrm{ft}^{2}{ }^{\circ} \mathrm{F}$ were calculated.

\section{ACKNOWLEDGMENTS}

The authors wish to acknowledge significant contributions to this work by the following individuals:
N. C. Shirley - Capsule design
W. L. Conant - Irradiation
D. L. Zimmerman - Post-irradiation examination
W. V. Cummings - Microprobe examination
R. E. Smith - Metallography

Particular acknowledgment is given to Dr. E. L. Zebroski and Dr. C. N. Spalaris for their comprehensive review and guidance in the preparation of this report.

\section{REFERENCES}

1. Sodium Cooled Reactors Fast Ceramic Reactor Development Program, Twentieth Quarterly Report, August to October, 1966, (GEAP-5292).

2. General Electric Test Reactor Applications Data and Customer Service Guide, April 1966 (APIO-1021).

3. Lyon, W. L., Ryer, C. M., Craig, C. N., "Laboratory Scale Preparation of Plutonia-Urania Fast Reactor Fuel", Am. Inst. Chem. Engr. 63, 1967.

4. Rider, B. F., et al., Determination of Neodymium 148 in Irradiated Uranium and Plutonium as a Measure of Burnup, October, 1968 (GEAP-5354).

5. Rosenbaum, H. S., et al., Electron Probe Micro-Analysis of Radioactive Materials, June 1967 (GEAP-5344).

6. Robertson, J. A. L., Skdo in Fuel Irradiations, June 1961 (CRFD-835).

7. Krankota, J. C., Craig, C. N., The Melting Point of Plutonia-Urania Mixed Oxides Irradiated to High Burnup, July 1969 (GEAP-13515).

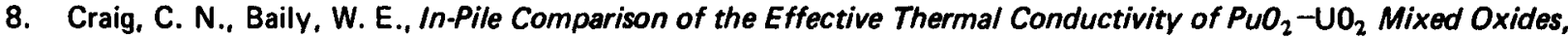
January 1968 (GEAP-5556).

9. Hausner, H., Nelson, R. C., Correlation of $\mathrm{UO}_{2}$ Microstructures from In-Pile and Out-of-Pile Experiments, 1964 (GEAP-4535).

10. Potter, T. J., and Elyard, C. A., Columnar Grain Growth in Uranium Dioxide, Proceedings of the British Ceramic Society, No. 7, Nuclear Engineering and Ceramics, Stoke-on-Trent, 1967.

11. Craig, C. N., Hull, G. R., and Baily, W. E., Fuel Cladding Heat Transfer Coefficients for Oxide Fuel Rods, (GEAP-5748).

12. Duncan, R. N., Cantley, D. A., Perry, K. J., Nelson, R. C., Fuel Swelling/Fast Reactor Mixed Oxide Fuels, Transactions of Conference on Fast Reactor Fuel Element Technology, April 13-15, 1971.

13. Sodium Cooled Reactors Fast Ceramic Reactor Development Program, Twenty-Fourth Quarterly Report, October, 1967, (GEAP-5541).

14. Perry, K. J., Nelson, R. C., and Rubin, B. F., “High Burnup Performance of Mixed Oxide Fuel to 120,000 MWd/Te," Trans. Am. Nuclear Society, Nov. 1967.

15. Rubin, B. F., Perry, K. J., The Irradiation of Urania-Plutonia Fuel to $125,000 \mathrm{MWd} / \mathrm{Te}$ in a Thermal Flux, March 1969 (GEAP-5761).

16. Nelson, R. C., Baumgartner, J. A., Perry, K. J., and Zebroski, E. L., Irradiation Induced Swelling Rates of $\mathrm{PuO}_{2}-\mathrm{UO}_{2}$ Fuel With Strong Radial Restraint, March 1971 (GEAP-13686). 17.

17. Sodium Cooled Reactors Fast Ceramic Reactor Development Program 28 Quarterly Report, August-October 1968, (GEAP-5700).

18. Lauritzen, T., Compatibility of Urania-Plutonia Fuels with Stainless Stee/s and Sodium, June 1968 (GEAP-5633). 


\section{GEAP-10385}

19. Anselin, F., The Role of Fission Products in the Swelling of Irradiated $\mathrm{UO}_{2}$ and $\left(\mathrm{U}, \mathrm{Pu} / \mathrm{O}_{2}\right.$ Fuel January 1969 (GEAP-5583).

20. Perry, K. J., Melde, G. E., McCarthy, W. H., and Duncan, R. N., Fuel-Clad Reactions Observed in Stainless Steel Clad Mixed Oxide Fuel Pin Irradiations, Transaction of Conference on Fast Reactor Fuel Element Technology. April 13-15, 1971. 
GEAP-10385

APPENDIX A

FABRICATION AND SELECT

POST IRRADIATION DATA

TABLE A-1

FUEL IMPURITY ANALYSIS - CAPSULE E5B

$\begin{array}{ll}\text { Pellets } & \text { Powder } \\ \text { (ppm) } & \text { (ppm) }\end{array}$

Ag

Al

20

As

Be

$\mathrm{Bi}$

$\mathrm{Ca}$

Cd

$\mathrm{Cr}$

$\mathrm{Cu}$

$\mathrm{Fe}$

$\mathrm{Ge}$

K

Li

Mg

Mo

Mn

(ppm)

(ppm)

$\mathrm{Na}$

$\mathrm{Ni}$

P

Po

$\mathrm{Si}$

Sn

$\mathrm{Ti}$

TI

V

$\mathrm{Zn}$

Total Metallic Impurity

596

1237

C

95

100

CI

$F$

N

8
$<1$

6

100

34 
TABLE A-2

\section{CLADDING CHEMICAL ANALYSIS AND MECHANICAL PROPERTIES DATA}

Impurity Analysis

Element

\section{C}

Mn

P

$\mathbf{S}$

Si

Ni

$\mathrm{Cr}$

Cb-Ta

Mo

$\mathrm{Cu}$

8

$\mathrm{N}_{2}$
Percent

0.05

1.16

0.023

0.009

0.72

9.32

18.20

0.91

0.14

0.20

0.0012

0.056
Room Temperature Tensile Test

347 SS Cladding

Welded and Drawn

$\begin{array}{lr}\text { Tensile Strength (psi) } & 105,000 \\ \text { Yield Strength (psi) } & 51,000 \\ \text { Percent Elongation } & 39 \\ \text { Grain Size (ASTM) } & 6-8\end{array}$

\section{TABLE A-3}

RELATIVE ACTIVITY OF ISOTOPES - CAPSULE E5B

\begin{tabular}{|c|c|c|c|}
\hline $\begin{array}{l}\text { Positiona } \\
\text { Number }\end{array}$ & $\begin{array}{c}\text { ZrNb-95 } \\
\text { (Relative) } \\
\pm 15 \%\end{array}$ & $\begin{array}{l}\text { La-140 } \\
\text { (Relative) } \\
\pm 15 \%\end{array}$ & Other Isotopes Observed \\
\hline $1 A^{\prime}$ & 150 & & Co-60 \\
\hline $1 \mathrm{~A}$ & 175 & & $\mathrm{Co}-60, \mathrm{Cr}-51$ \\
\hline $1 B$ & 2,600 & 180 & Cs-137, Ru-103 \\
\hline $1 \mathrm{C}$ & 11,000 & 1,700 & $R u-103$ \\
\hline $1 D$ & 7,500 & 1,200 & Ru-103 (High) \\
\hline $1 E$ & 7,000 & 1,000 & Ru-103 \\
\hline 1F & 11,000 & 1,700 & Ru-103 \\
\hline $2 A^{\prime}$ & 475 & & \\
\hline $2 A$ & 350 & & Co-60, Cr-51 \\
\hline 2B & $<1,100$ & 80 & I-131, Cs-134, 137, Cs-136 \\
\hline $2 \mathrm{C}$ & 7,000 & 450 & Ru-103 (High) \\
\hline $2 \mathrm{D}$ & 27,000 & 4,800 & Ru-103 \\
\hline $2 \mathrm{E}$ & 15,000 & 3,300 & $R u-103$ \\
\hline $2 F$ & 11,000 & 2,500 & $\mathrm{Ru}-103$ \\
\hline $2 \mathbf{G}$ & 10,000 & 2,300 & Ru-103 \\
\hline $2 H$ & 7,000 & 900 & Ru-103 \\
\hline 21 & 10,000 & 2,100 & Ru-103 \\
\hline
\end{tabular}

\footnotetext{
Refers to Figure 4-1
} 
TABLE A4

FISSION GAS ANALYSIS - CAPSULE E5B

Pellets

A. Total Gas Volume:

B. Fission Gas Volume:

C. Fission Gas Release:

D. Gas Chromatograph:

$$
\mathrm{Ar}+\mathrm{O}_{2}
$$

$\mathrm{N}_{2}$

$\mathrm{CO}$

$\mathrm{CH}_{4}$

$\mathrm{CO}_{2}$

$\mathrm{Xe}$

$\mathrm{Kr}$

$\mathrm{He}$

$\mathrm{H}_{2}$

E. Gamma Counting

Total Atoms Kr-85

F. Mass Spectrograph:

$\mathrm{Kr}-83$

84

85

86

$\mathrm{Xe}-131$

132

134

136

$\mathrm{Xe}$

$\mathrm{Xe}+\mathrm{Kr}$
$104 \mathrm{cc}$

99 cc

$91 \%$

$\%$

Trace

0.10

0.04

Not Detected

Not Analyzed

85.5

8.71

4.85

0.18

$1.6 \times 10^{19}$

$\%$

12.26

30.04

6.59

51.11

10.60

18.82

28.17

42.41

$92.1 \pm 3 \%$
Powder

$93 \mathrm{cc}$

$86 \mathrm{cc}$

$78 \%$

$\%$

0.4

0.5

Not Detected

Not Detected

Not Analyzed

81.7

8.55

7.40

Not Detected

$1.9 \times 10^{19}$

$\%$

13.16

30.16

6.86

49.69

11.12

18.51

28.35

42.01

$89.9 \pm 3 \%$ 


\section{TABLE A-5}

BURNUP AND ISOTOPIC DISTRIBUTION - CAPSULE E5B

Pellets

Powder

A. Burnup from

Neodymium 148/

Heavy element ratio

$\mathrm{MWd} / \mathrm{Te}$

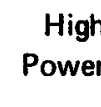

159,000

$\pm 6,000$

Lower

High

Power

Lower

Power

138,000

Power

B. Burnup from

Heavy Isotope Ratios

$\mathrm{MWd} / \mathrm{Te}$

145,000

122,000

138,000

110,000

$\pm 18,0 \mathrm{CO} 0$

$\pm 15,800$

$\pm 17,900$

$\pm 14,300$

C. Post-Irradiation

Isotopic Content

(Atom \%)

$\begin{array}{rr}\text { U-234 } & 0.47 \\ \text { U-235 } & 30.40 \\ \text { U-236 } & 2.29 \\ \text { U-238 } & 66.84 \\ \text { Pu-239 } & 67.95 \\ \text { Pu-240 } & 27.34 \\ \text { Pu-241 } & 4.02 \\ \text { Pu-242 } & 0.68 \\ \text { Pu-239 } & 24.70\end{array}$

0.49

0.42

0.48

29.82

32.16

1.88

2.00

1.61

65.78

67.76

65.76

72.45

70.52

74.46

23.84

25.34

22.25

3.25

3.56

2.90

0.47

0.39

U.238

28.40

26.90

D. Pre-Irradiation

Isotopic Content

(Atom \%)

$$
\begin{aligned}
& \text { U-234 } \\
& U-236 \\
& U-235 \\
& U-238 \\
& \text { Pu-239 } \\
& \text { Pu-240 } \\
& \text { Pu-241 } \\
& \text { Pu-242 } \\
& \text { Pu-239 } \\
& U-238
\end{aligned}
$$

0.47

0.47

0.11

0.11

40.10

38.10

59.90

61.90

90.91

91.00

8.36

8.30

0.69

0.70

0.03

0.04

49.40

47.70

24.50

24.50 


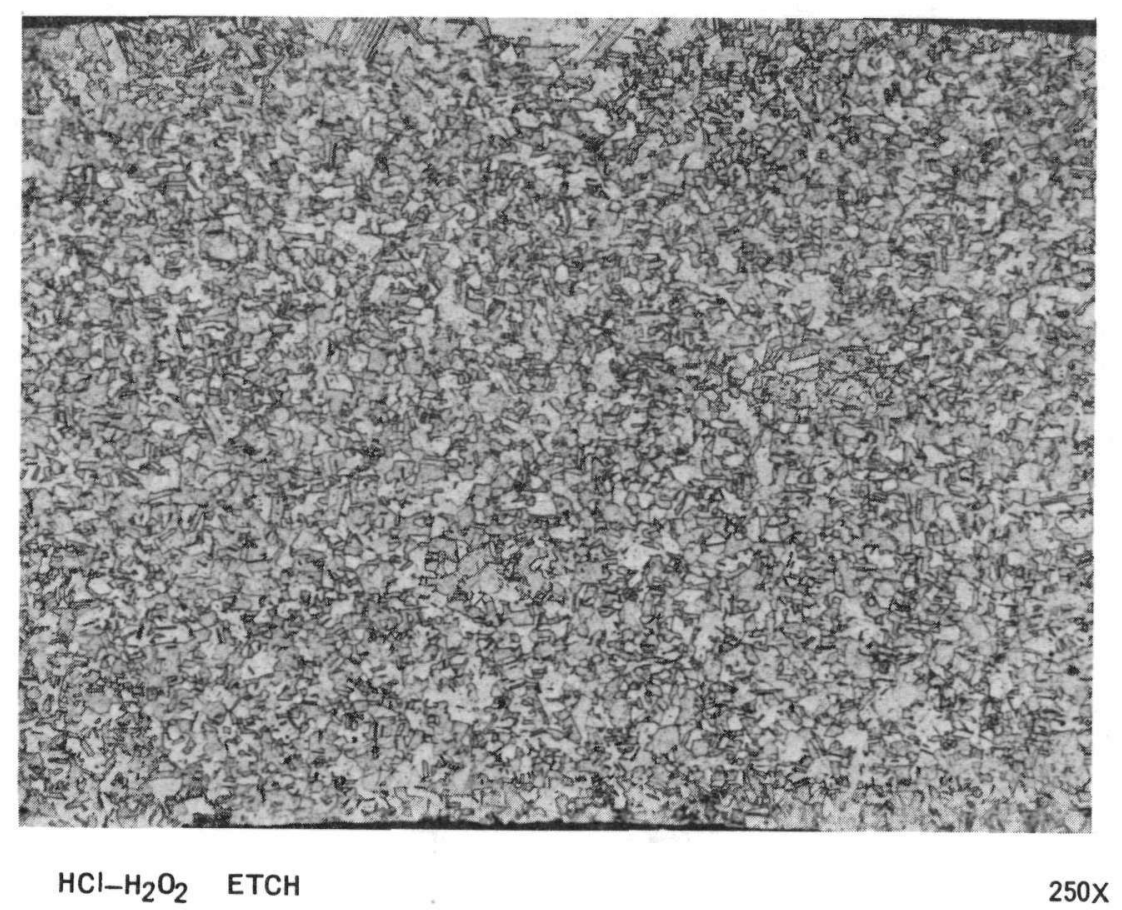

Figure A-1 Metallography of Type 347 Stainless Steel Cladding 

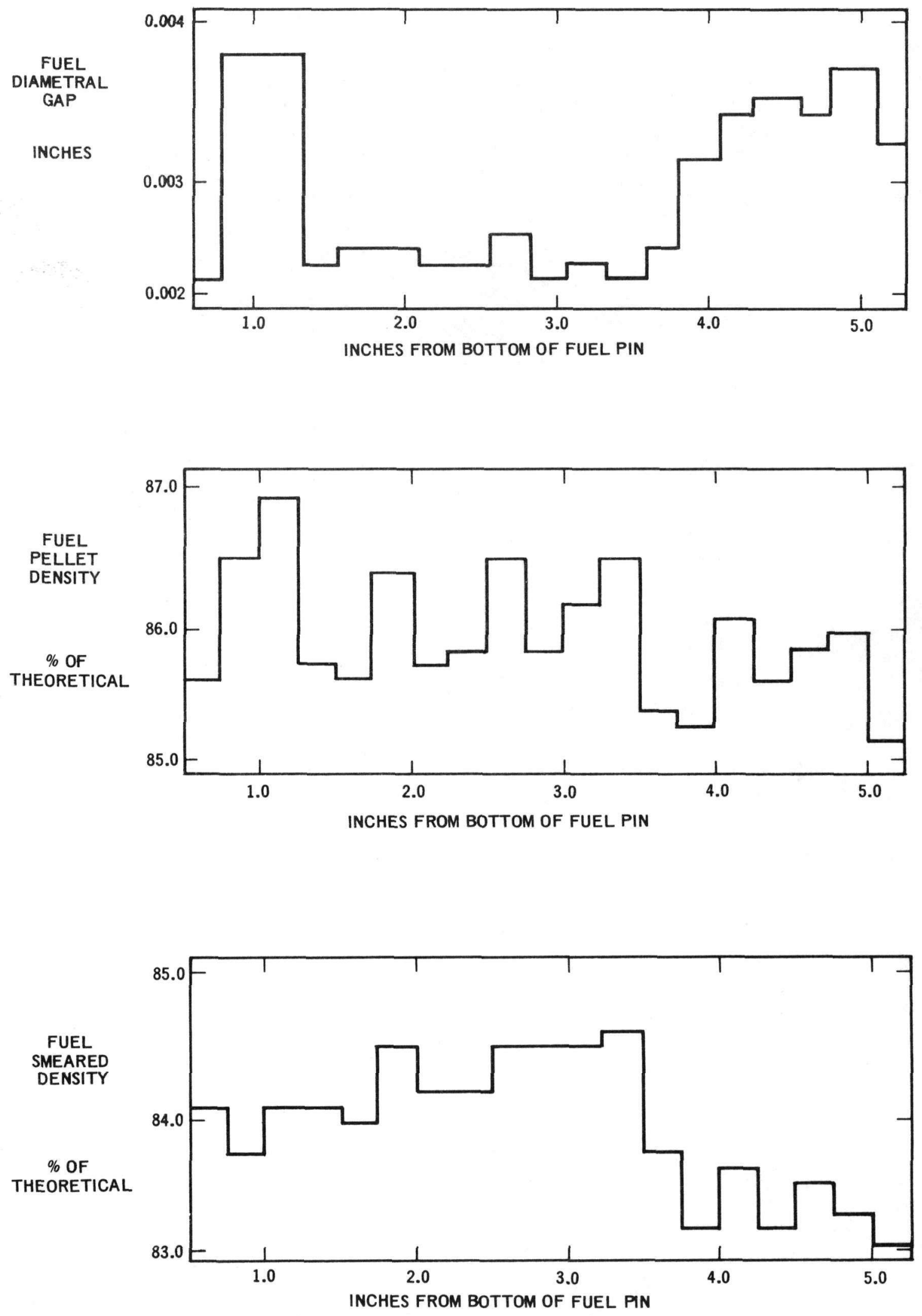

Fijure A-2 Axial Plot of Parameters Which May Affect Cladding Diametral Expansion 
APPENDIX B

FISSION GAS CALCULATIONS

1. TOTAL FISSION GAS + ARGON FILL GAS COLLECTED:

Pellets

$104 \mathrm{cc}$
Powder

$93.3 \mathrm{cc}$

\title{
2. CALCULATION OF TOTAL QUANTITY OF FISSION GAS GENERATED:
}

A. Fuel burnup based on Nd-148 - heavy metal ratio analysis, MWd/Te Average of four analyses $=136,000 \mathrm{MWd} / \mathrm{Te}$

B. Mass of heavy metal per pin

Pellets

gms oxide gms metal
28.16

24.81
Powder

28.30

24.93

C. For pellets (200 MeV/fission)

\author{
$136,000 \mathrm{MWd} / \mathrm{Te} \times \frac{2.7 \times 10^{15} \frac{\text { fission }}{\mathrm{gm}(\mathrm{U}+\mathrm{Pu})}}{1 \mathrm{MWd} / \mathrm{Te}} \times 24.81 \mathrm{gm}(\mathrm{U}+\mathrm{Pu})$ \\ $\frac{0.32 \text { atom gas }}{\text { fission }} \times \frac{22,400 \mathrm{cc}}{6.023 \times 10^{23} \text { atoms }}=108 \mathrm{cc}$ fission gas generated \\ For Powder $=108 \mathrm{cc}$
}


3. CALCULATION OF FISSION GAS \% RELEASED:

A. From gas chromatography

$\begin{array}{lll} & \text { Pellets } & \text { Powder } \\ \% & 8.71 & 8.55 \\ \mathrm{Xe} \% & 85.5 & 81.7\end{array}$

Calculation of fission gas quantity collected:

For Pellets

(104) $(01087+0.855)=98.0 \mathrm{cc}$ released

For Powder

(93.3) $(0.086+0.817)=84.3 \mathrm{cc}$ released

Calculation of \% gas released:

For Pellets

$\frac{98.0}{108}=91 \%$

B. From Gamma Spectroscopy:

Total $\mathrm{Kr}-85 / \mathrm{cc}$ of gas collected, atoms/cc

For Pellets

$1.54 \times 10^{17}$

\section{For Powder}

$\frac{84.3}{108}=78 \%$

1. Calculation of total atoms $\mathrm{Kr}-85$ collected:

For Pellets

\section{For Powder}

$2.10 \times 10^{17}$

\section{For Powder}

$$
2.10 \times 10^{17} \frac{\text { atoms }}{\mathrm{cc}} \times 93.3 \mathrm{cc}=1.96 \times 10^{19} \text { atoms } \mathrm{Kr}-85
$$

2. Calculation of $\mathrm{Kr}-85$ yield, \%

From fuel analysis:

$$
\frac{P u}{U+P u}=0.245
$$$$
\frac{P u-239}{P u}=0.909
$$ 


$$
\begin{aligned}
& \frac{U}{U+P u}=0.755 \\
& \frac{U-235}{U}=0.401
\end{aligned}
$$

Fraction $\mathrm{U}-235=(0.755)(0.401)$

$$
=0.302
$$

Fraction Pu-239 $=(0.245)(0.909)=0.223$

Relative probability of fission of U-235 vs Pu-239

$$
=(0.302)(572 \text { Barns })=172
$$

For Pu-239 (0.223) $(960)=214$

Relative fission yields of Kr-85 (per Katcoff, 1964)

$$
\begin{aligned}
& \text { Pu-239 }=0.099 \% \\
& U-235=0.273 \%
\end{aligned}
$$

Average probability of $\mathrm{Kr}-85$ yield of $\mathrm{Pu}-239$ vs $\mathrm{U}-235$

$$
\begin{aligned}
& 0.099 \times \frac{214}{172+214}=0.055 \% \\
& 0.273 \times \frac{172}{172+214}=0.122 \% \\
& \text { TOTAL } \overline{0.177 \%} \\
& =0.00177 \text { atom } / \text { fission }
\end{aligned}
$$

$\mathrm{Kr}-85$ Yield $=0.177 \%$

For Pellets

$1.60 \times 10^{19}$ atoms $\mathrm{Kr}-85 \times \frac{0.32 \text { atom gas }}{0.00177 \text { atom } \mathrm{Kr}-85}$

For Powder

$1.96 \times 10^{19} 132 \mathrm{cc}$ gas

Calculation of $\%$ gas released:

For Pellets

$\frac{108}{108}=100 \%$ gas release $*$

\section{For Powder}

$\frac{132}{108}=122 \%$ gas release

"These numbers may result from erroneous Kr-85 gamma counting results. 
-

$\bullet$ 


\section{APPENDIX C \\ METALLOGRAPHY AND AUTORADIOGRAPHY RESULTS}

\section{C-1 PELlet fUEL, SECTION A, FIGURE C-1}

\author{
Linear Power \\ Fuel Center Temperature \\ Fuel Surface Temperature \\ Cladding Inside Surface Temperature \\ Void Volume
}

\author{
$20.4 \mathrm{~kW} / \mathrm{ft}$ \\ $2600^{\circ} \mathrm{C}$ \\ $1110^{\circ} \mathrm{C}$ \\ $660^{\circ} \mathrm{C}\left(1220^{\circ} \mathrm{F}\right)$ \\ $3 \%$
}

The central void occupied only $3 \%$ of the cross-sectional area in this specimen. Since this void size is inconsistent with the fuel densification as indicated by the columnar grain radius $(80 \%)$, it was concluded that molten fuel from the upper section relocated to this region. The overall fuel morphology was similar to pellet fuel section E (5.2.2) which ran at $22 \mathrm{~kW} / \mathrm{ft}$.

With the exception of one isolated region of 0.002 in. no significant fuel-cladding chemical interaction was observed. Cladding inside surface temperatures in this region were calculated to be $1220^{\circ} \mathrm{F}$ compared to $1330^{\circ} \mathrm{F}$ for specimen E. Autoradiographs are presented in Figure C-9. No distinctive characteristics were noted.

\section{C-2 PELLet fUel, SECTION H, FIGURE C-2 \\ Linear Power \\ Fuel Center Temperature \\ $23.5 \mathrm{~kW} / \mathrm{ft}$ \\ Fuel Surface Temperature \\ $2600^{\circ} \mathrm{C}$ \\ Cladding Inside Surface Temperature \\ $1260^{\circ} \mathrm{C}$ \\ Void Volume \\ $760^{\circ} \mathrm{C}\left(1400^{\circ} \mathrm{F}\right)$ \\ $28 \%$}

This specimen represents the peak power section of the pellet fuel where the central void occupied $28 \%$ of the fuel volume. This void size is inconsistent with the initial fuel density and it is reasonable to consider that the fuel melted to the radius of the center void and subsequently moved to the bottom area of the pin. $A$ thin band of fuel exhibiting the characteristic dendritic microstructure associated with molten fuel was visible and covered about $20 \%$ of the inside surface of the center void (see Figure C-2).

The fuel area adjacent to the cladding contained large quantities of metallic material, extending in several places as wedge-shaped sections well into the fuel. A radial crack in the fuel which extended to the central void was associated with each of these wedges. This metallic material was attacked by an electrolytic etch in a manner similar to the cladding and exhibited neither alpha or beta-gamma activity on autoradiographs, Figure C-8. A minimum cladding thickness of 0.0116 inch was measured in this section, indicating a loss of about 0.004 inch of cladding material. Cladding inside surface temperature of $1400^{\circ} \mathrm{F}$ was calculated.

\section{C-3 POWDER FUEL, SECTION B, FIGURE C-3}

\author{
Linear Power \\ Fuel Center Temperature \\ Fuel Surface Temperature \\ Cladding Inside Surface Temperature \\ Void Volume
}

\author{
$23.3 \mathrm{~kW} / \mathrm{ft}$ \\ Molten \\ $1260^{\circ} \mathrm{C}$ \\ $760^{\circ} \mathrm{C}\left(1400^{\circ} \mathrm{F}\right)$ \\ 0
}

This specimen represents the peak power section of the powder fuel and is equivalent to section $\mathrm{H}$ of the pellet fuel, (see Figure C-2). Since the bottom end of the powder fuel ran at highest power, fuel relocated into rather than away from this area. The central fuel exhibited a dendritic structure and was surrounded by a pore-free ring typical of molten fuel. A 100X radial micrograph is shown in Figure C-4, with a 500X section showing fuel-cladding reaction. A minimum cladding thickness of 0.0119 inch was measured exclusive of the affected zone. Autoradiographs are presented in Figure C-8. Decreased beta-gamma activity was noted in the dendritic central region. 


\section{C-4 POWDER FUEL, SECTION A, FIGURE C-5}

The top of this specimen is the opposite face of the transverse sample described in Appendix C-3. Typical fuel-cladding interaction was observed at the top area of this section. The character of this reaction changed from severe to insignificant over an axial distance equivalent to about one cladding thickness (see designated area in Figure C-5). Since the fuel structure showed no significant change in this area, it was concluded that end cooling reduced the cladding temperature below the reaction threshold. At the lower end of the fuel column gross diffusion of the mixed oxide into the $\mathrm{UO}_{2}$ powder insulator was observed. The full extent of this mixing may be seen in Figure C-6, where autoradiographs delineate fission product and fuel activity. The loop of fused material through the insulator powder is not easily explained. Recent microprobe examinations of material with similar appearance indicates that it may be cesium uranate.

\section{C-5 AUTORADIOGRAPHY}

Alpha and beta-gamma autoradiographs of the fuel sections are shown in Figures C-6 through C-9. In addition to the specimens previously discussed there is included a longitudinal specimen which illustrates the bridges found across the central void of the pellet fuel (subsection G). This bridge had enhanced beta-gamma activity suggesting a high concentration of fission products. Axial gamma scans also indicated the location of these bridges.

An attempt was made to expose all autoradiographs for the same time period. Since the time was only 2 seconds, this was difficult and some variation in exposure time occurred.

The exposure of highly enriched fuel in a thermal flux resulted in severe surface-to-center flux depression in the fuel. The high activity levels found in the outer fuel were therefore expected. Fission-product migration may have enhanced this phenomenon. 


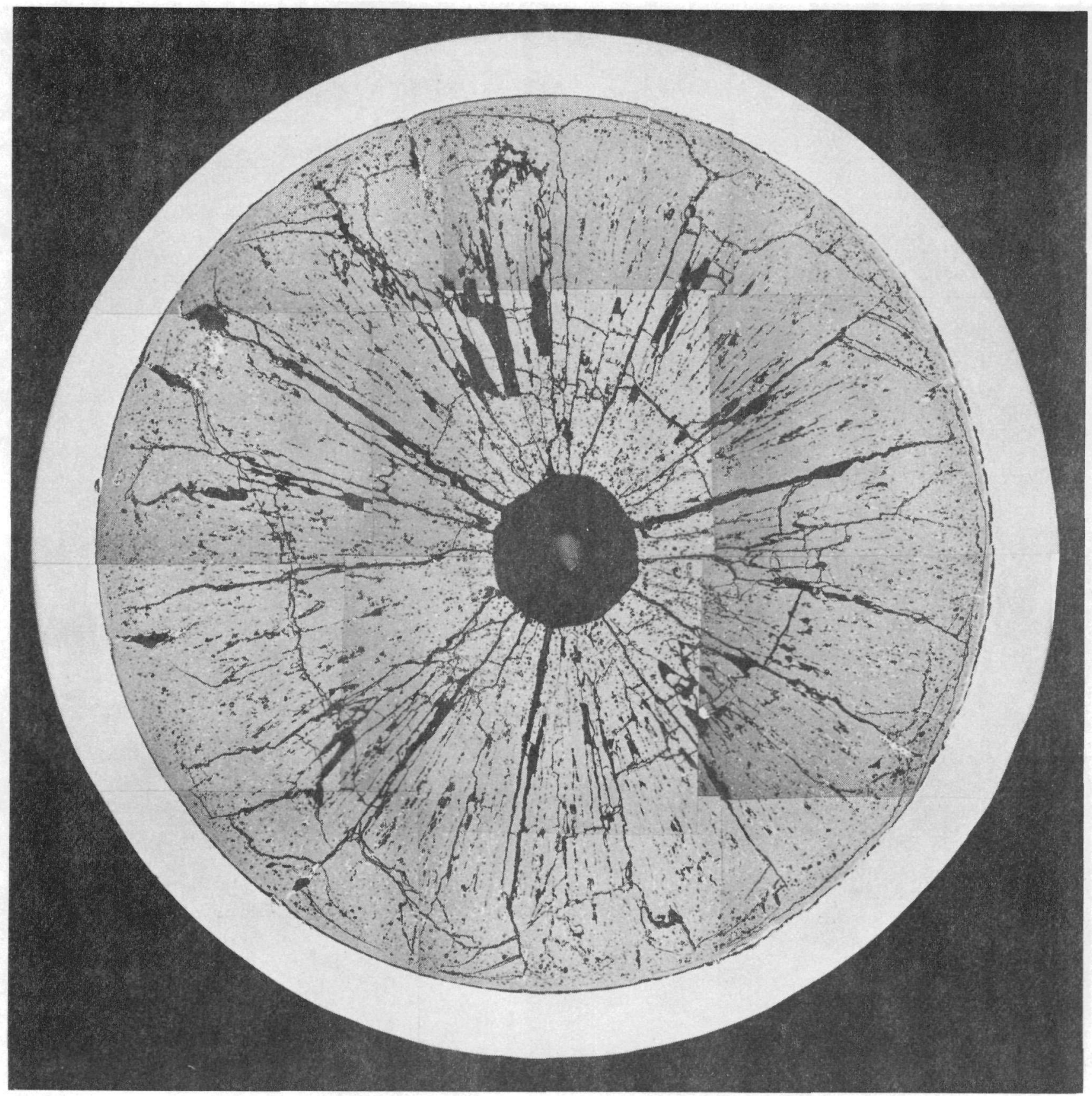

LINEAR POWER

FUEL CENTER TEMPERATURE

FUEL SURFACE TEMPERATURE

CLAD INSIDE SURFACE TEMPERATURE

VOID VOLUME
$20.4 \mathrm{~kW} / \mathrm{ft}$

$2600^{\circ} \mathrm{C}$

$1110^{\circ} \mathrm{C}$

$660^{\circ} \mathrm{C}\left(1220^{\circ} \mathrm{F}\right)$

$3 \%$

Figure C-1 Pellet Fuel Section A 


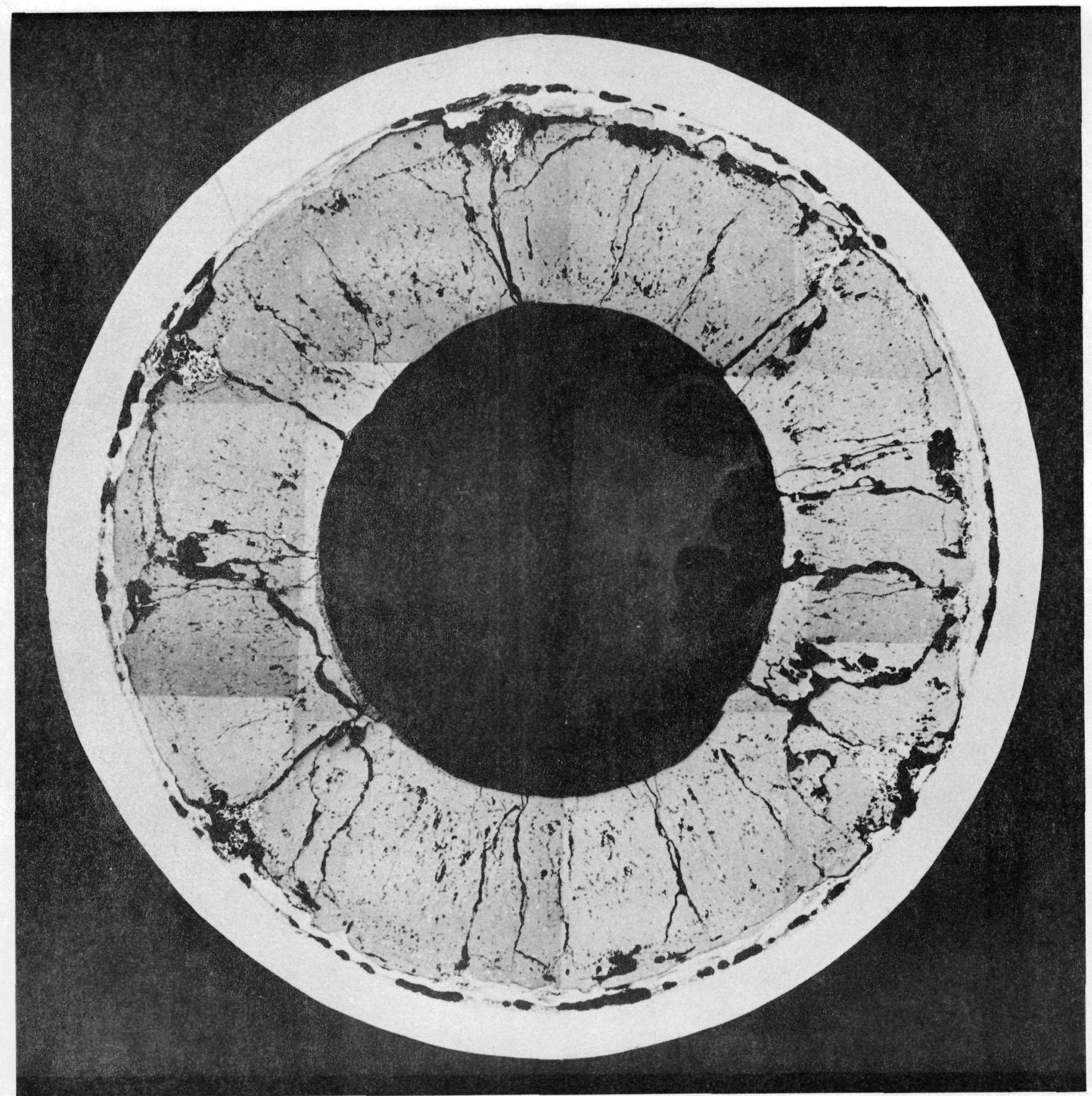

LINEAR POWER

FUEL CENTER TEMPERATURE

FUEL SURFACE TEMPERATURE

CLAD INSIDE SURFACE TEMPERATURE

VOID VOLUME
$23.5 \mathrm{~kW} / \mathrm{ft}$

$2600^{\circ} \mathrm{C}$

$1260^{\circ} \mathrm{C}$

$760^{\circ} \mathrm{C}\left(1400^{\circ} \mathrm{F}\right)$

$28 \%$

Figure C-2 Pellet Fuel Section H 


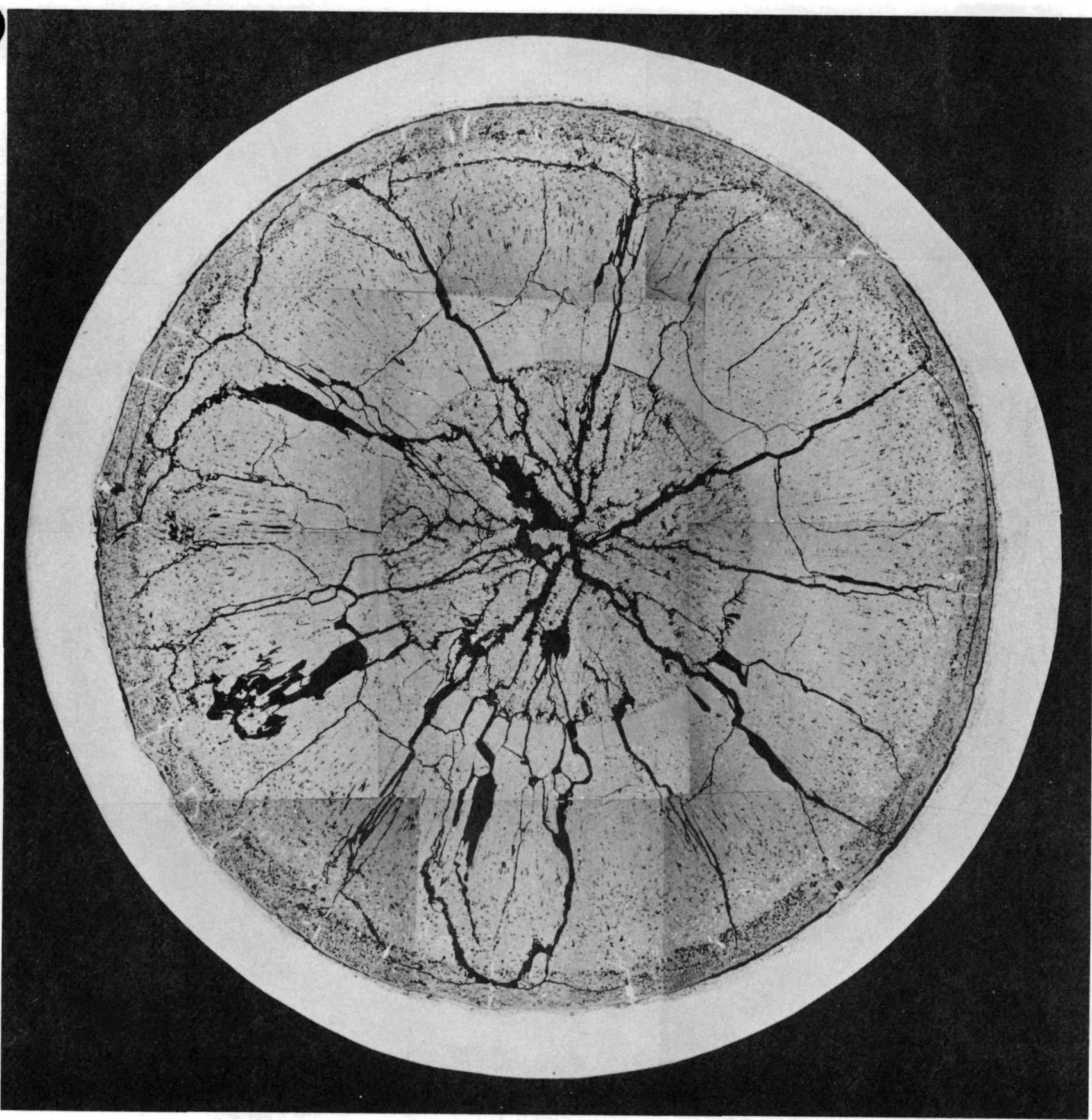

$30 \mathrm{x}$

LINEAR POWER

FUEL CENTER TEMPERATURE

FUEL SURFACE TEMPERATURE

CLAD INSIDE SURFACE TEMPERATURE VOID VOLUME
$23.5 \mathrm{~kW} / \mathrm{ft}$

MOLTEN

$1260^{\circ} \mathrm{C}$

$760^{\circ} \mathrm{C}\left(1400^{\circ} \mathrm{F}\right)$

Figure C-3 Powder Fuel Section B 
GEAP-10385

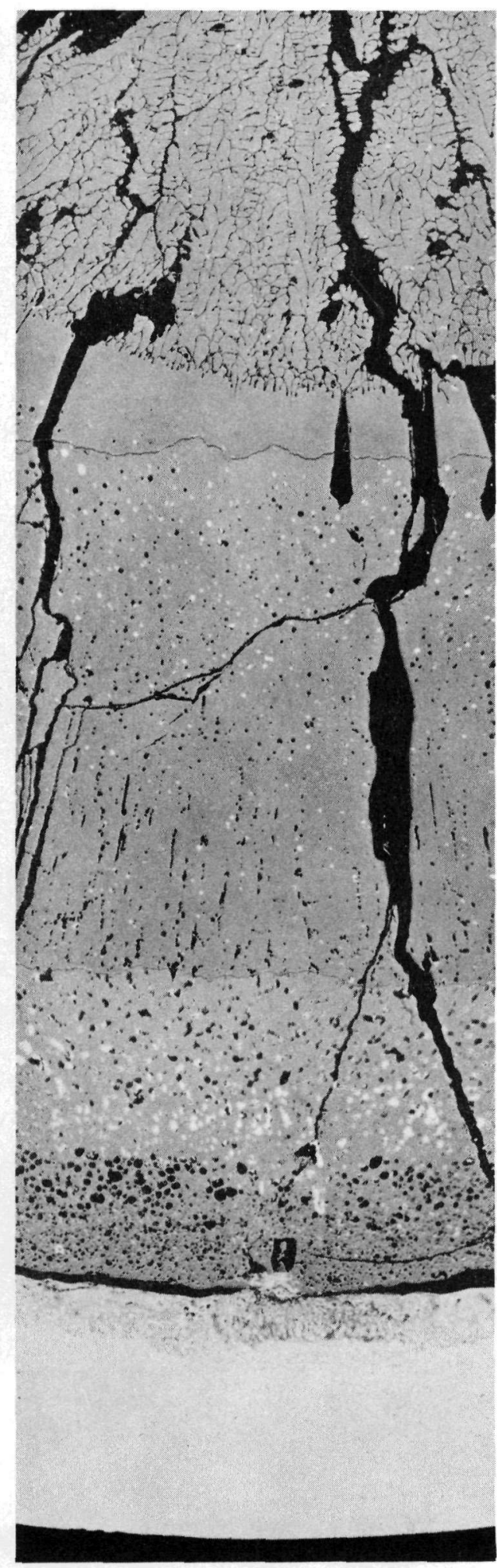

AS POLISHED RADIAL SECTION
Photos reduced to $74 \%$

for reproduction
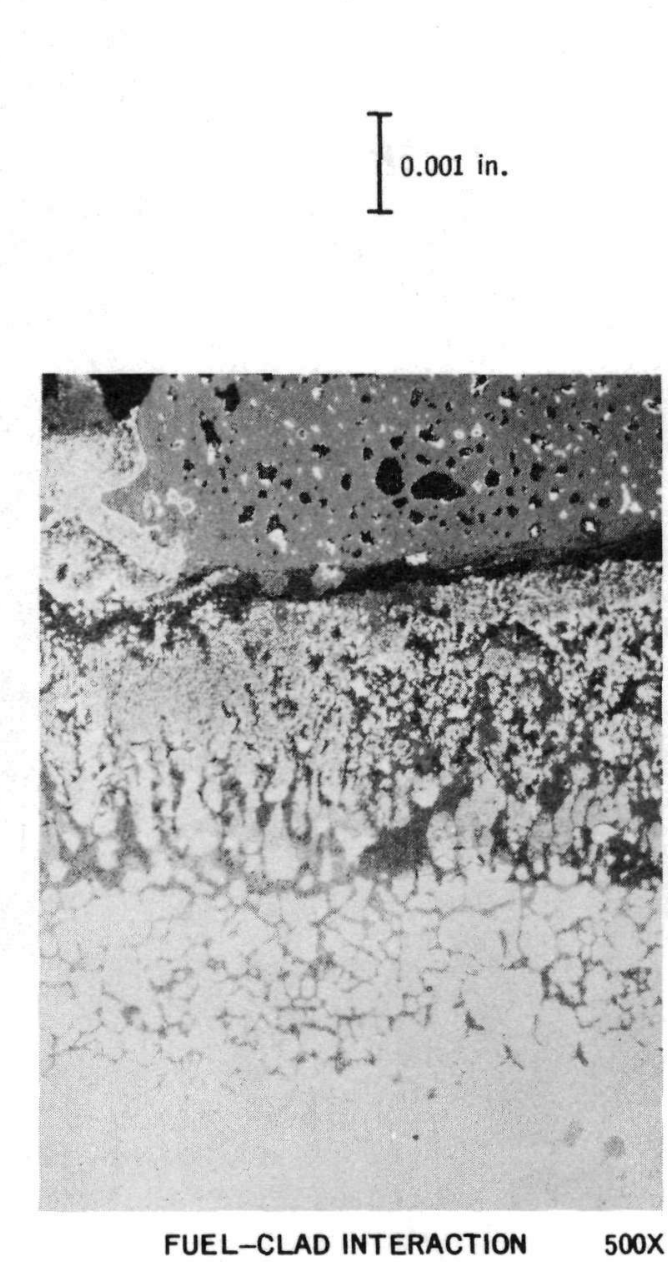


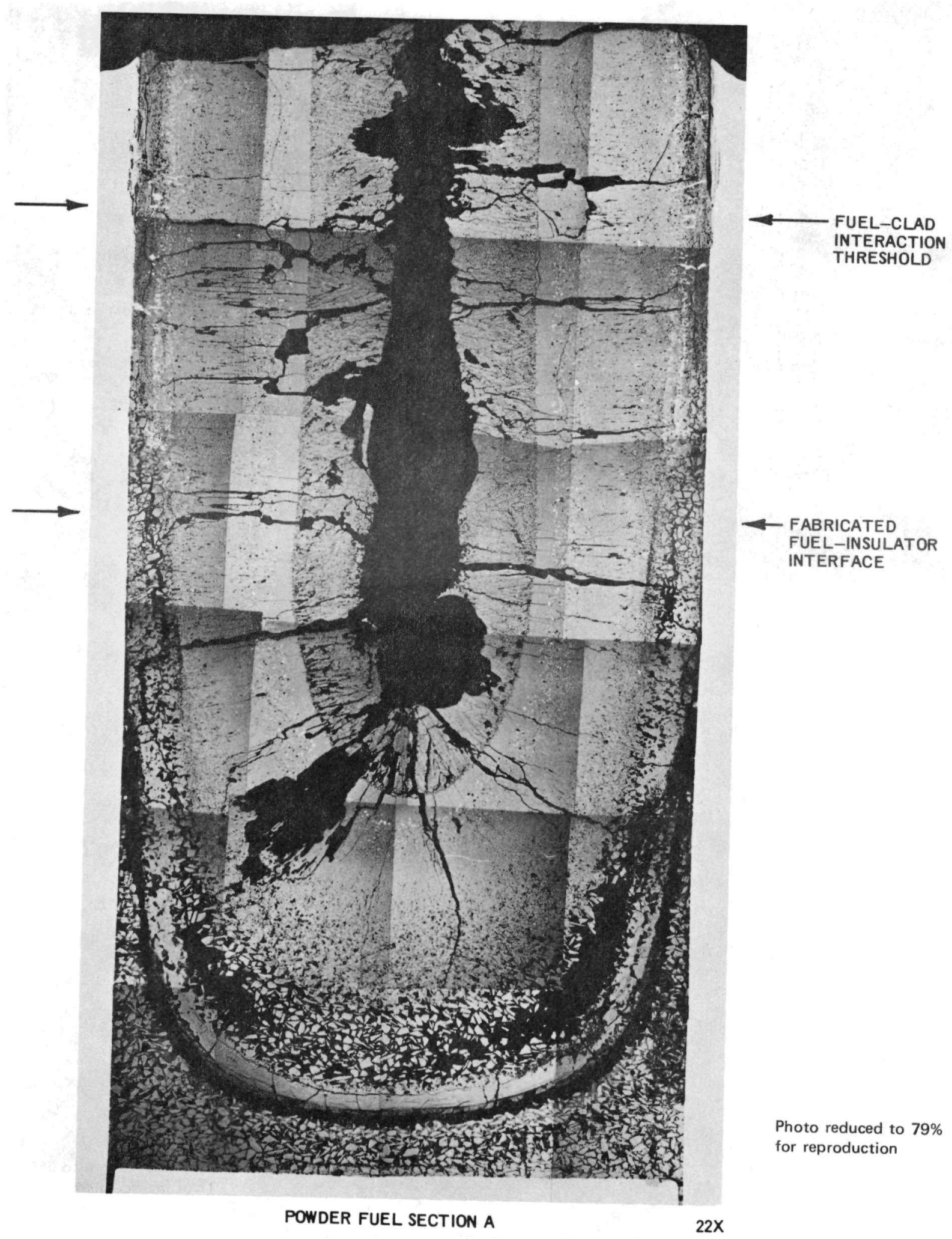

Figure C-5 Powder Fuel Section A 

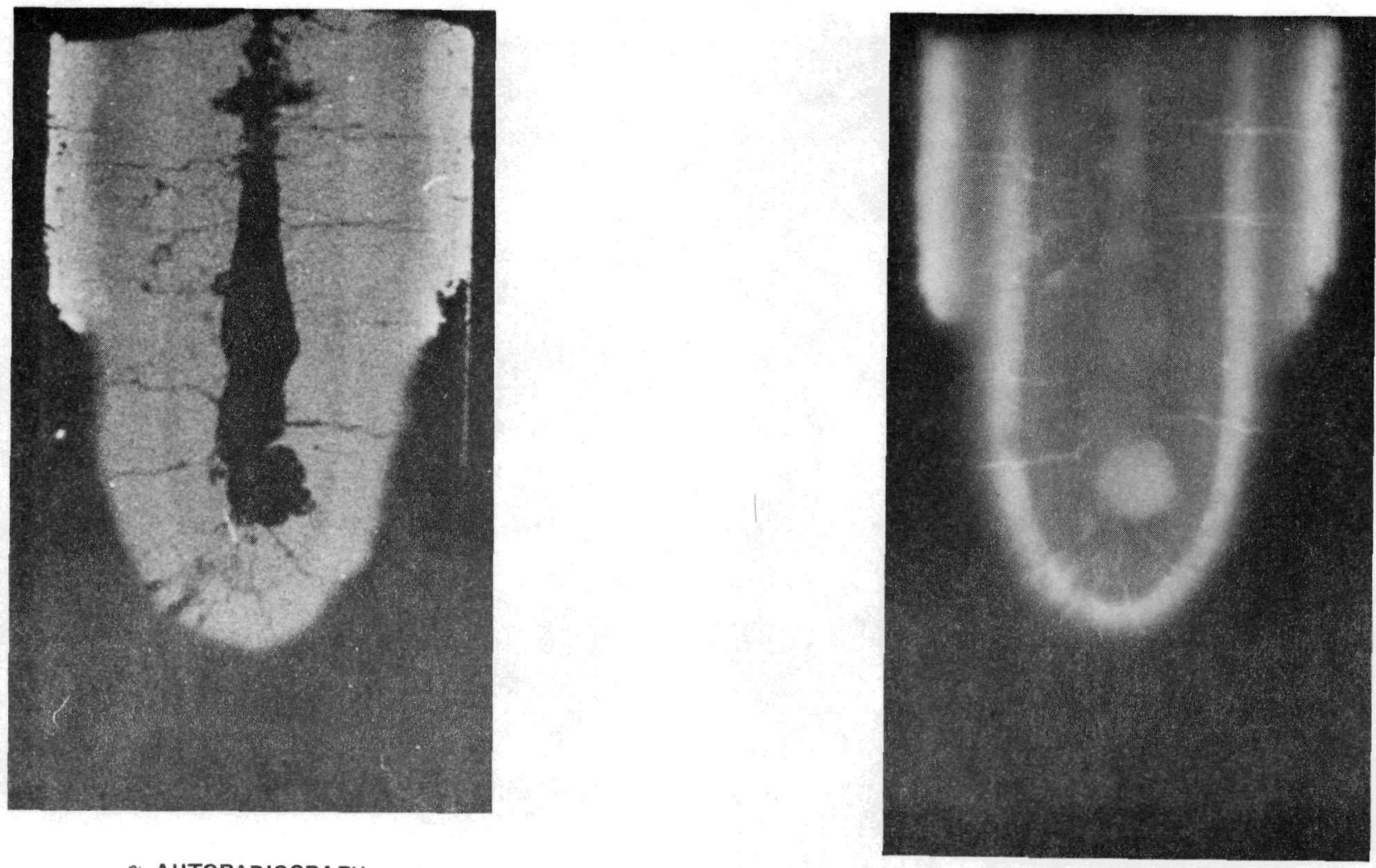

a AUTORADIOGRAPH

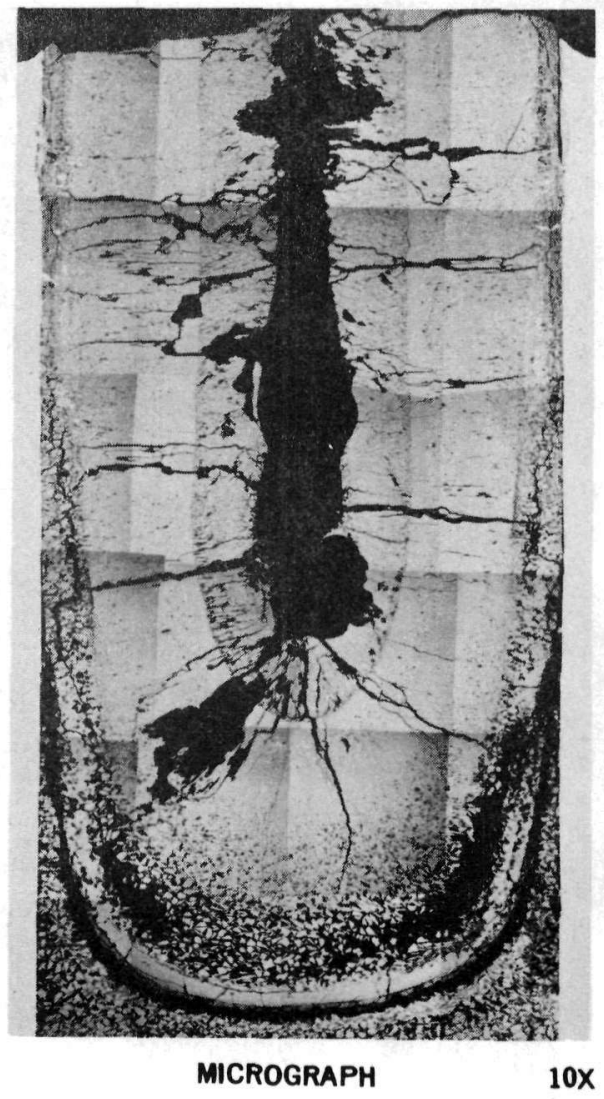

$\beta-\gamma$ AUTORADIOGRAPH

Photos reduced to $95 \%$ for reproduction

Figure C-6 Powder Fuel Section A Autoradiography 


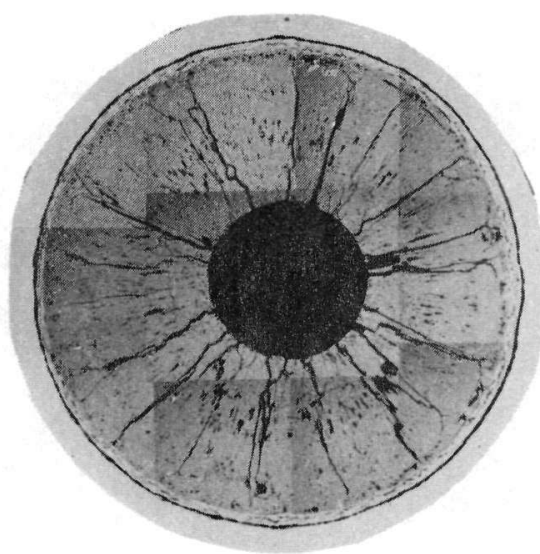

PELLET FUEL SECTION $10 x$

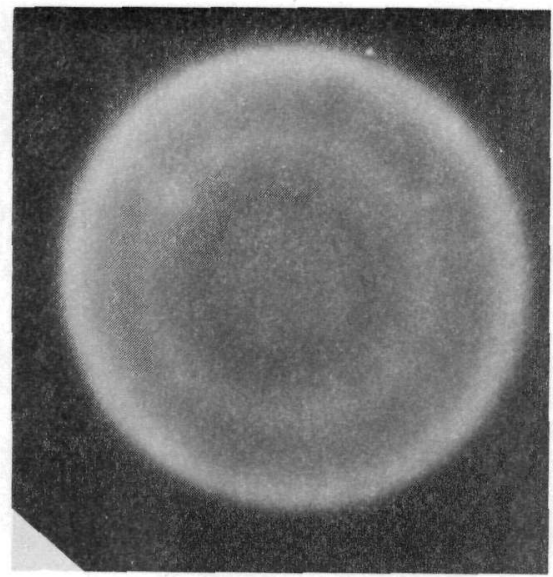

$\beta-\gamma$ AUTORADIOGRAPH

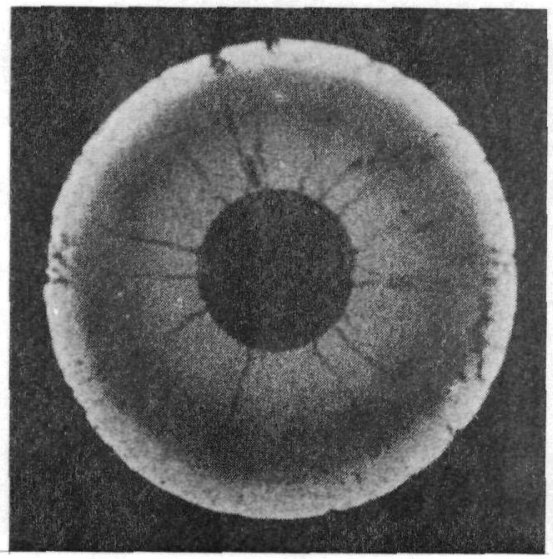

a AUTORADIOGRAPH

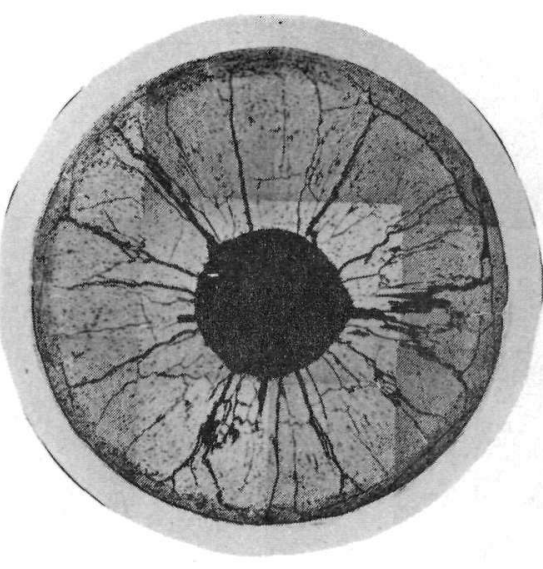

POWDER FUEL SECTION $10 \mathrm{x}$

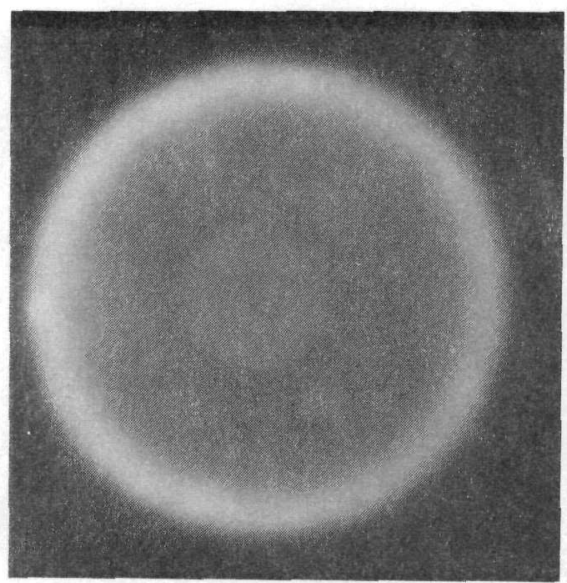

$\beta-\gamma$ AUTORADIOGRAPH

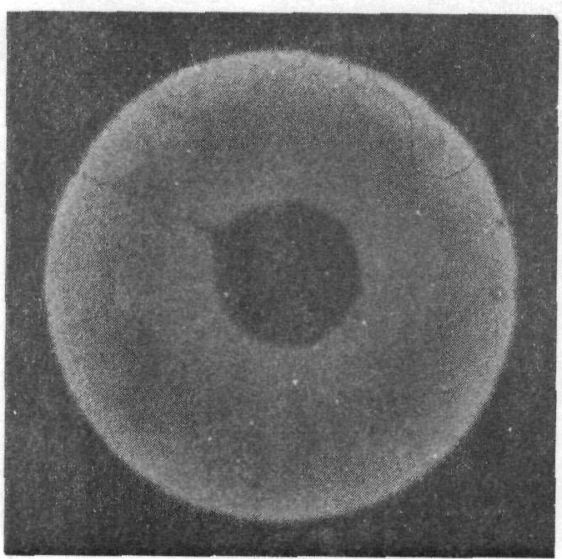

$\alpha$ AUTORADIOGRAPH
Photos reduced to $86 \%$ for reproduction

Figure C-7 Pellet Fuel Section E and Powder Fuel Section E Autoradiography 

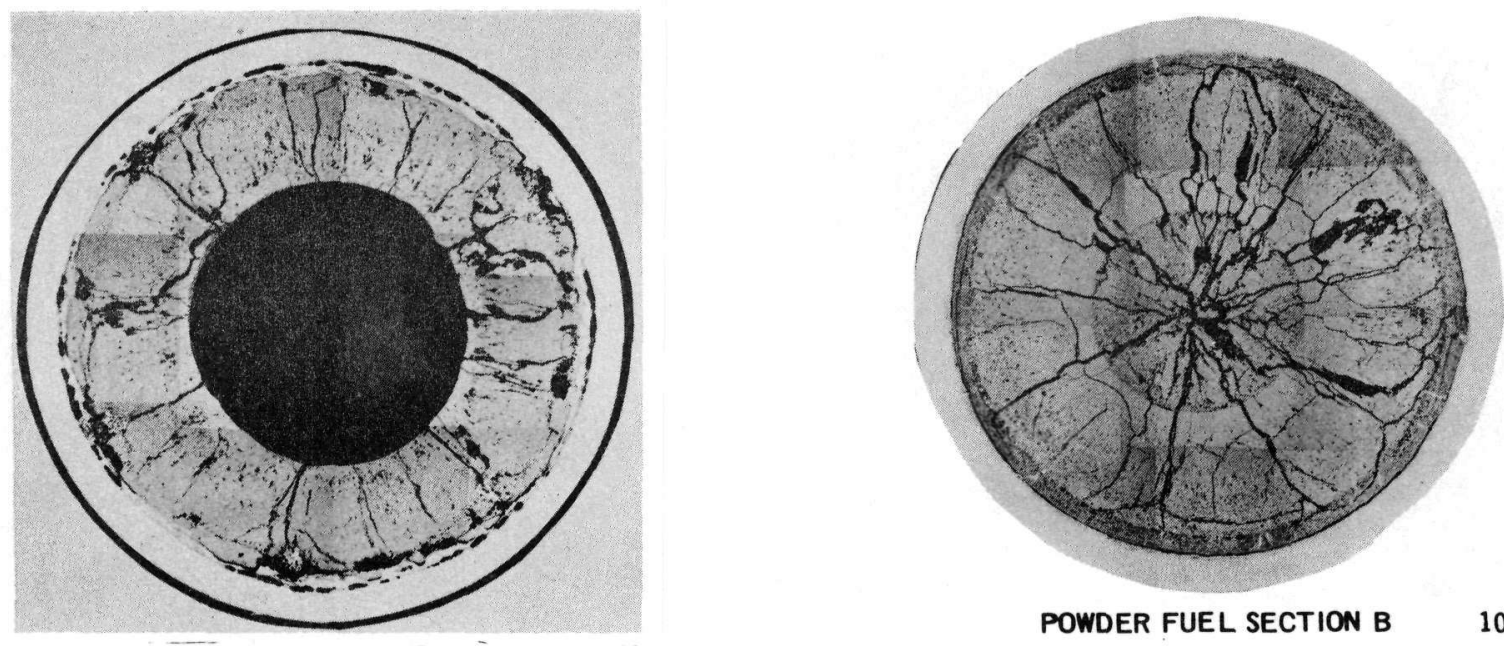

PELLET FUEL SECTION H $10 \mathrm{X}$

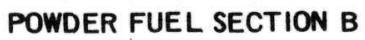

$10 \mathrm{X}$

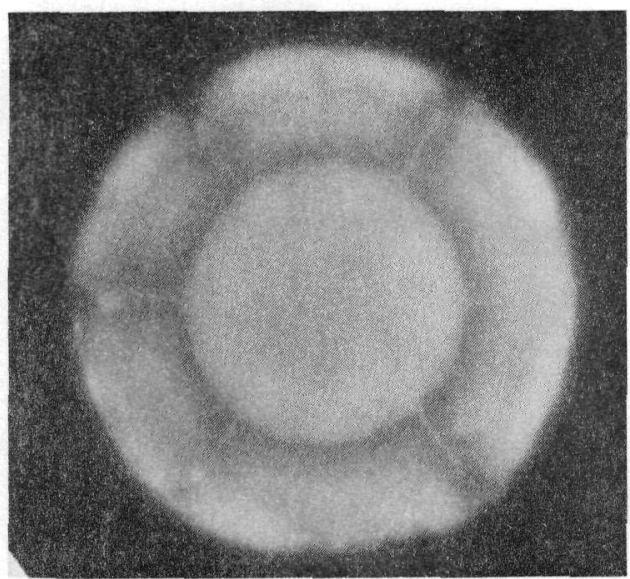

$\beta-\gamma$ AUTORADIOGRAPH

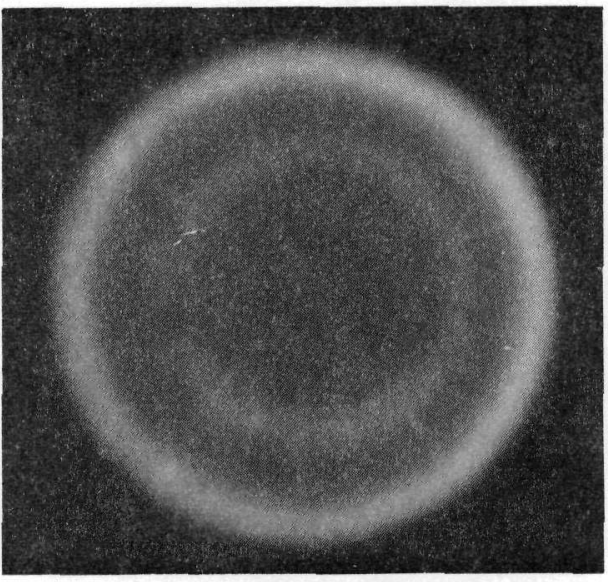

$\beta-\gamma$ AUTORADIOGRAPH

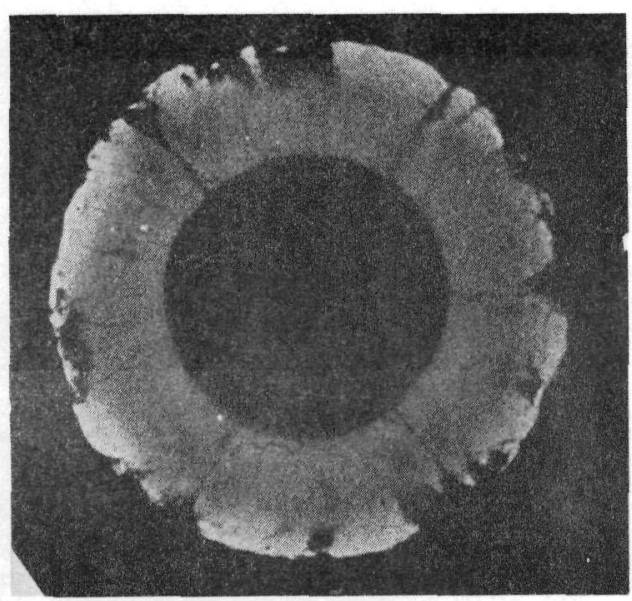

a AUTORADIOGRAPH
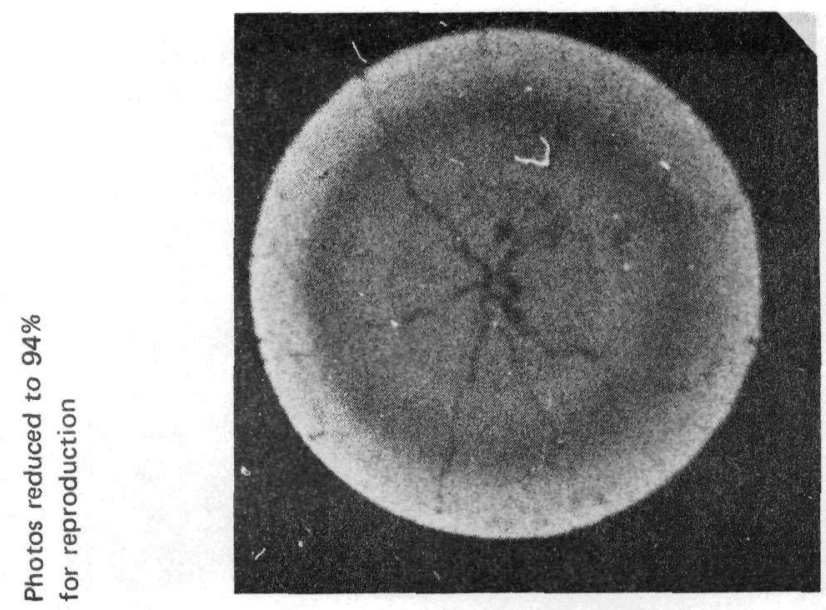

a AUTORADIOGRAPH

Figure C-8 Powder Fuel Section B and Pellet Fuel Section H Autoradiography 


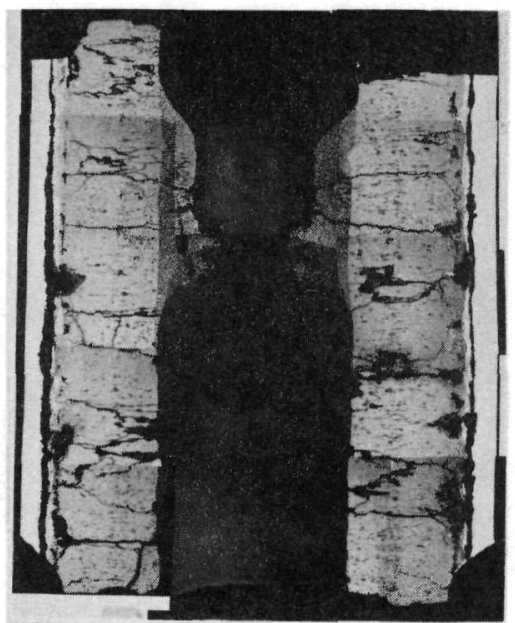

PELLET FUEL SECTION G

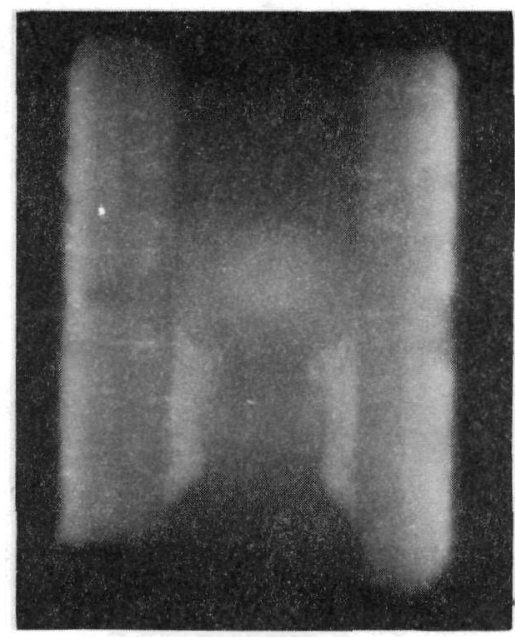

$\beta-\gamma$ AUTORADIOGRAPH

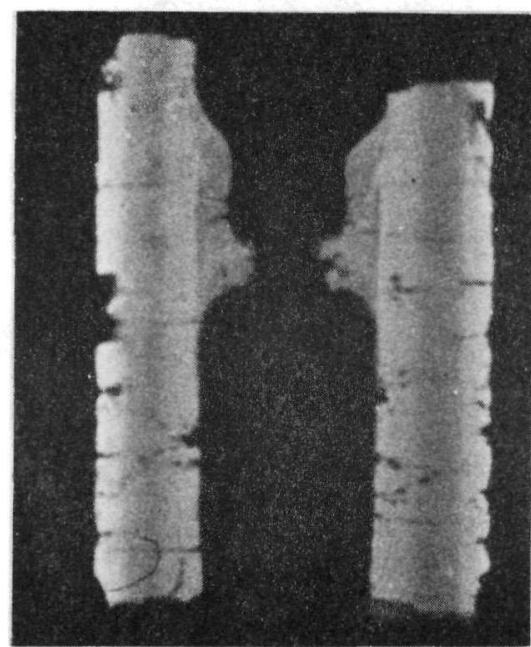

a AUTORADIOGRAPH

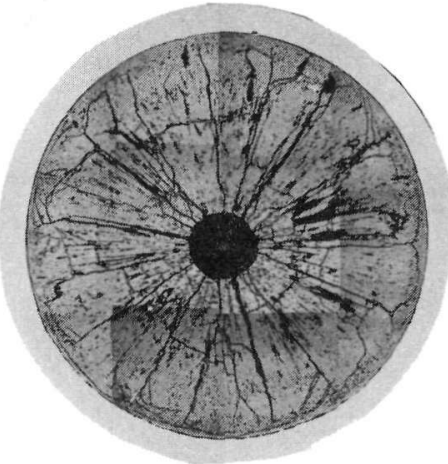

PELLET FUEL SECTION A 10X

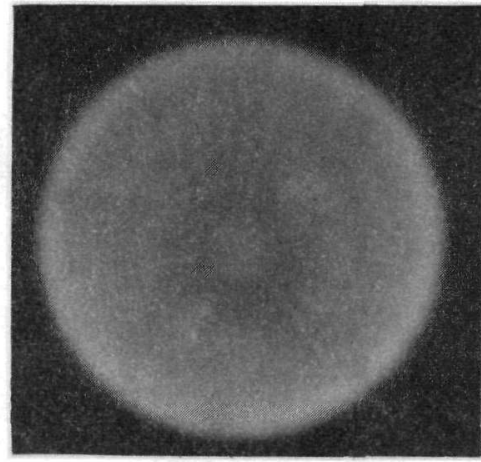

$\beta-\gamma$ AUTORADIOGRAPH

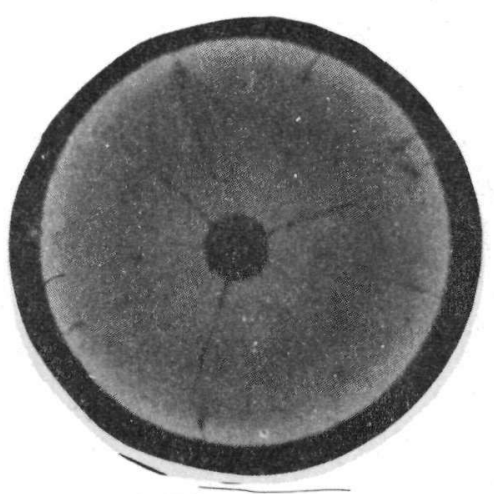

a AUTORADIOGRAPH

rnotos reduced to $74 \%$

for reproduction

Figure C-9 Pellet Fuel Section A and Pellet Fuel Section G Autoradiography 


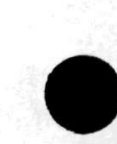




\section{DISTRIBUTION}

Director, Contracts Division

U. S. Atomic Energy Commission

San Francisco Operations Office

2111 Bancroft Way

Berkeley, California 94704

RDT Site Office

U.S. Atomic Energy Commission

General Electric Company

310 DeGuigne Drive

Sunnyvale, California 94086

Chief, California Patent Group

U. S. Atomic Energy Commission

San Francisco Operations Office

P. O. Box 808

Livermore, California 94550

Manager

Westinghouse Electric Corporation

Advanced Reactors Division

P. O. Box 158

Madison, Pennsylvania 15663

Division of Reactor Development and Technology, Headquarters

U.S. Atomic Energy Commission

Washington, D. C. 20545

Attn: Assistant Director, Engineering Standards

Division of Reactor Development and Technology. Headquarters

U. S. Atomic Energy Commission

Washington, D. C. 20545

Attn: Assistant Director, Nuclear Safety

Division of Reactor Development and Technology, Headquarters

U. S. Atomic Energy Commission

Washington, D. C. 20545

Attn: Assistant Director, Plant Engineering

Division of Reactor Development and Technology, Headquarters

U. S. Atomic Energy Commission

Washington, D. C. 20545

Attn: Assistant Director, Program Analysis

Division of Reactor Development and Technology, Headquarters

U.S. Atomic Energy Commission

Washington, D. C. 20545

Attn: Assistant Director, Project Management
1 Division of Reactor Development and Technology, Headquarters U. S. Atomic Energy Commission Washington, D. C. 20545

Attn: Assistant Director, Reactor Engineering

Division of Reactor Development and Technology, Headquarters U.S. Atomic Energy Commission Washington, D. C. 20545

Attn: Assistant Director, Reactor Technology

Division of Reactor Development and Technology. Headquarters U. S. Atomic Energy Commission Washington, D. C. 20545

1

Attn: Chief, Fuels and Materials Branch

Division of Reactor Development and Technology, Headquarters U. S. Atomic Energy Commission Washington, D. C. 20545

Attn: Chief, Fuel Engineering Branch

Division of Reactor Development and Technology. Headquarters U. S. Atomic Energy Commission Washington, D. C. 20546

Attn: Chief, Reactor Vessels Branch

Assistant Director for

Pacific Northwest Programs, RDT

U.S. Atomic Energy Commission

P. O. Box 550

Richland, Washington 99352

RDT Site Office

U. S. Atomic Energy Commission Argonne National Laboratory

Building 2,

1 Argonne, Illinois 60439

RDT Site Office

U. S. Atomic Energy Commission Atomics International

P. O. Box 1446

2

Canoga Park, California 91304

RDT Site Office

U.S. Atomic Energy Commission Argonne National Laboratory P. O. Box 2108

Idaho Falls, Idaho 83401 
RDT Senior Site Representative U. S. Atomic Energy Commission P. O. Box 2325

San Diego, California 92112

Division of Naval Reactors

Chief, Nuclear Materials Branch

U. S. Atomic Energy Commission

Washington, D. C. 20545

Director

Division of Reactor Licensing

U. S. Atomic Energy Commission

Washington, D. C. 20545

Director

Metallurgy Division

Argonne National Laboratory

9700 South Cass Avenue

Argonne, Illinois 60439

Manager, FFTF Project

Pacific Northwest Laboratory

P. O. Box 999

Richland, Washington 99352

Manager

Chemistry and Metallurgy Division

Pacific Northwest Laboratory

P. O. Box 999

Richland, Washington 99362

RDT Site Office

U.S. Atomic Energy Commission

Oak Ridge National Laboratory

P. O. Box X

Oak Ridge, Tennessee 37830

Director

Division of Reactor Standards

U. S. Atomic Energy Commission

Washington, D. C. 20545

Division of Technical

Information Extension

U. S. Atomic Energy Commission

P. O. Box 62

Oak Ridge, Tennessee 37831

Director

LMFBR Program Office

Argonne National Laboratory

9700 South Cass Avenue

Argonne, Illinois 60439

Director

Chemical Engineering Division

Argonne National Laboratory

9700 South Cass Avenue

Argonne, Illinois 60439
FFTF Fuels Department

Pacific Northwest Laboratory

P. O. Box 999

Richland, Washington 99352

1 Division Leader (CMB)

Chemistry and Metallurgy Division

Los Alamos Scientific Laboratory

P. O. Box 1663

3

Los Alamos, New Mexico 87544

Director

Metallurgy and Materials

Science Division

Brookhaven National Laboratory

2

Upton, New York 11973

Division Chief, M \& S Division

NASA - Lewis Research Center

21000 Brookpark Road

6

Cleveland, Ohio 44135

Director

Nuclear Safety Program

Oak Ridge National Laboratory

P. O. Box Y

$1 \quad$ Oak Ridge, Tennessee $\mathbf{3 7 8 3 0}$

General Manager

Westinghouse Electric Corporation

Bettis Atomic Power Laboratory

P. O. Box 79

1 West Mifflin, Pennsylvania 15122

Associate Manager

Materials Engineering Department

Battelle Memorial Institute

Columbus Laboratories

505 King Avenue

Columbus, Ohio 43201

Manager, Nuclear Laboratories

Combustion Engineering Inc.

Nuclear Division

Prospect Hill Road

Windsor, Connecticut 06095

Manager, Plutonium Chemistry

and Ceramics Fuels Development

Nuclear Materials and Equipment

Corporation

Plutonium Laboratory

Leechburg, Pennsylvania 15656

Head, Fuels and Materials

Atomic Power Development Associates

1911 First Street

Detroit, Michigan 48226

1 Director

Metals and Ceramics Division

Oak Ridge National Laboratory

P. O. Box X

Oak Ridge, Tennessee $\mathbf{3 7 8 3 0}$ 
Director, Liquid Metal

Engineering Center

Atomics International

P. O. Box 1449

Canoga Park, California 91304

Manager-Advanced Development Activity

General Electric Company

Knolls Atomic Power Laboratory

P. O. Box 1072

Schenectady, New York 12301

Director, LMFBR Technology Program

Atomics International

P. O. Box 309

Canoga Park, California 91304

Director

Nuclear Development Center

The Babcock and Wilcox Company

Atomic Energy Division

Lynchburg, Virginia 24501

Laboratory Assistant Director

Gulf General Atomic Incorporated

P. O. Box 608

San Diego, California 92112

Manager, Research

United Nuclear Corporation

Research and Engineering Center

Grasslands Road

Elmsford, New York 10523
1 K-2 Group Leader

Reactor Division

Los Alamos Scientific Laboratory

P. O. Box 1663

Los Alamos, New Mexico 87544

1 Westinghouse Electric Corporation

Technical Director

Advanced Reactors Division

P. O. Box 158

Madison, Pennsylvania 15663

1 Manager

Liquid Metal Information Center

Atomics International

P. O. Box 1449

1

Canoga Park, California 91304

Irradiation Coordinator

EBR-II Project

Argonne National Laboratory

P. O. Box 2528

1

Idaho Falls, Idaho 83401

Experiment Manager

EBR-II Project

Argonne National Laboratory

9700 South Cass Avenue

Argonne, Illinois 60439

Director

Reactor Safety and Analysis Devision

Argonne, Illinois, 60439 